\title{
Analysis of the Reuse of Uranium Recovered from the Reprocessing of Commercial LWR Spent Fuel
}

January 2009

Prepared by

G. D. Del Cul

L. D. Trowbridge

J. P. Renier

R. J. Ellis

K. A. Williams

B. B. Spencer

E. D. Collins 


\title{
DOCUMENT AVAILABILITY
}

Reports produced after January 1, 1996, are generally available free via the U.S. Department of Energy (DOE) Information Bridge:

Web site: http://www.osti.gov/bridge

Reports produced before January 1, 1996, may be purchased by members of the public from the following source:

\author{
National Technical Information Service \\ 5285 Port Royal Road \\ Springfield, VA 22161 \\ Telephone: 703-605-6000 (1-800-553-6847) \\ TDD: $703-487-4639$ \\ Fax: 703-605-6900 \\ E-mail: info@ntis.fedworld.gov \\ Web site: http://www.ntis.gov/support/ordernowabout.htm
}

Reports are available to DOE employees, DOE contractors, Energy Technology Data Exchange (ETDE) representatives, and International Nuclear Information System (INIS) representatives from the following source:

Office of Scientific and Technical Information

P.O. Box 62

Oak Ridge, TN 37831

Telephone: 865-576-8401

Fax: 865-576-5728

E-mail: reports@osti.gov

Web site: http://www.osti.gov/contact.html

This report was prepared as an account of work sponsored by an agency of the United States Government. Neither the United States government nor any agency thereof, nor any of their employees, makes any warranty, express or implied, or assumes any legal liability or responsibility for the accuracy, completeness, or usefulness of any information, apparatus, product, or process disclosed, or represents that its use would not infringe privately owned rights. Reference herein to any specific commercial product, process, or service by trade name, trademark, manufacturer, or otherwise, does not necessarily constitute or imply its endorsement, recommendation, or favoring by the United States Government or any agency thereof. The views and opinions of authors expressed herein do not necessarily state or reflect those of the United States Government or any agency thereof. 
ORNL/TM-2007/207

ORNL/GNEP/LTR-2008-002

\title{
ANALYSIS OF THE REUSE OF URANIUM RECOVERED FROM THE REPROCESSING OF COMMERCIAL LWR SPENT FUEL
}
G. D. Del Cul
L. D. Trowbridge
J. P. Renier
R. J. Ellis
K. A. Williams
B. B. Spencer
E. D. Collins

Date Published: January 2009

\author{
Prepared by \\ OAK RIDGE NATIONAL LABORATORY \\ P.O. Box 2008 \\ Oak Ridge, Tennessee 37831-6283 \\ managed by \\ UT-Battelle, LLC \\ for the \\ U.S. DEPARTMENT OF ENERGY \\ under contract DE-AC05-00OR22725
}





\section{CONTENTS}

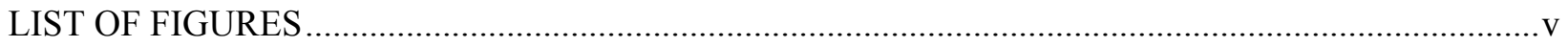

LIST OF TABLES …............................................................................................................. vii

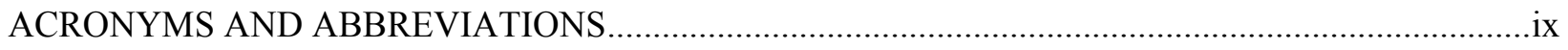

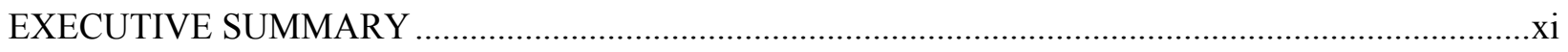

1. INTRODUCTION

1.1 OBJECTIVE

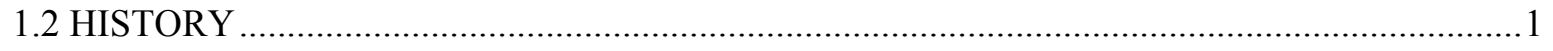

1.3 SCOPE

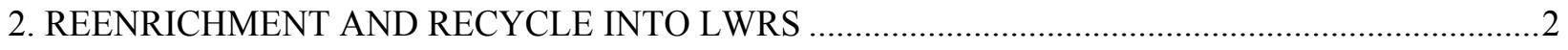

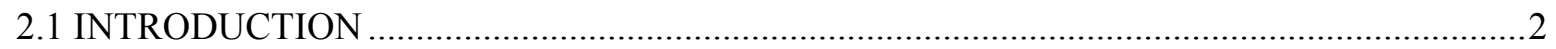

2.2 EFFECTS OF TRU ELEMENTS AND FISSION PRODUCTS ON RU …............................. 4

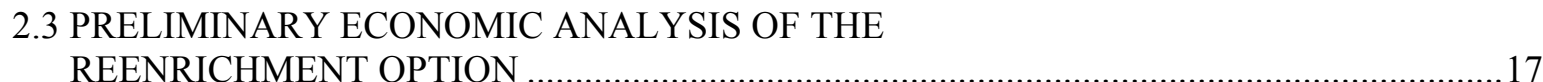

2.4 CONCLUSIONS REGARDING THE REENRICHMENT OPTION .....................................24

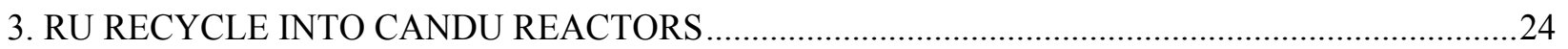

3.1 CAPABILITIES OF CANDU REACTORS ….........................................................2

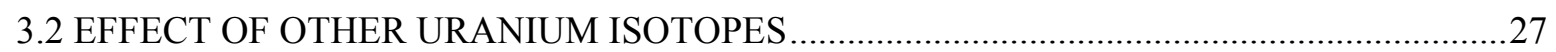

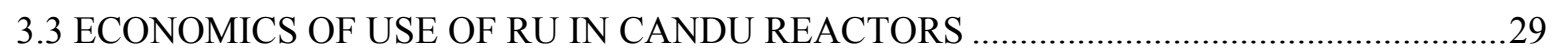

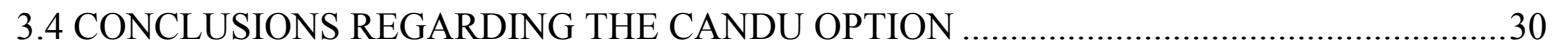

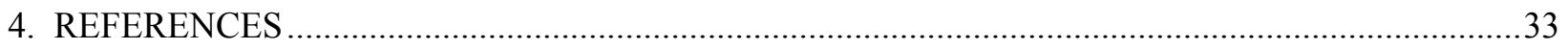

APPENDIX A: INDEPENDENT VERIFICATION OF RU ECONOMICS

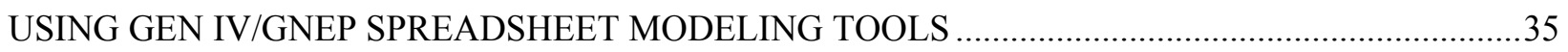

APPENDIX B: U.S. SPENT FUEL INVENTORY AND EXPECTED RU QUALITY ..........................43 



\section{LIST OF FIGURES}

FigurePage

1. Average composition of the U.S. spent fuel currently in storage at the reactor sites......... 1

2. Concentration of ${ }^{236} \mathrm{U}$ in uranium of the loaded enriched product as a function of reactor passes for the $33,000 \mathrm{MWd} / \mathrm{MTIHM}$ cases. 10

3. Additional ${ }^{235} \mathrm{U}$ required to compensate for the ${ }^{236} \mathrm{U}$ in uranium of the loaded enriched product as a function of reactor passes for the 33,000 MWd/MTIHM cases. ... 11

4. Concentration of ${ }^{236} \mathrm{U}$ in uranium of the loaded enriched product as a function of reactor passes for the combined 33,000 MWd/MTIHM (reactor pass 1) and 55,000 MWd/MTIHM (reactor passes 2 to 7 ) cases.

5. Additional ${ }^{235} \mathrm{U}$ required to compensate for the ${ }^{236} \mathrm{U}$ in uranium of the loaded enriched product as a function of reactor passes for the combined 33,000 MWd/MTIHM (reactor pass 1) and 55,000 MWd/MTIHM (reactor passes 2 to 7 ) cases. 12

6. Concentration of ${ }^{232} \mathrm{U}$ in uranium of the loaded enriched product as a function of reactor passes for the combined 33,000 MWd/MTIHM (reactor pass 1) and 55,000 MWd/MTIHM (reactor passes 2 to 7) cases. 12

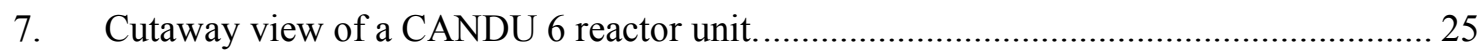

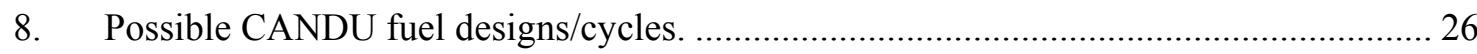

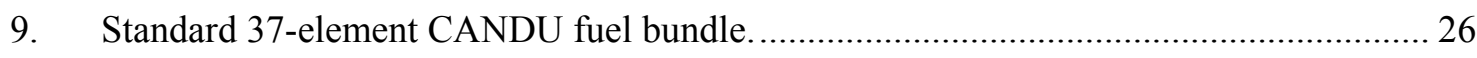

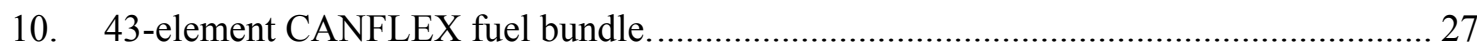

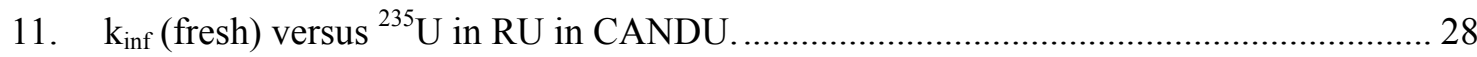

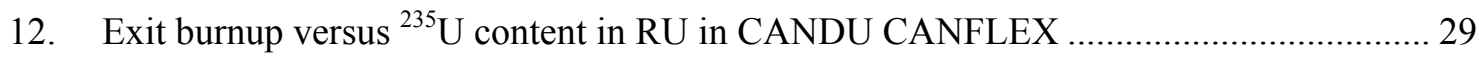

A-1. Equilibrium fuel cycle material balance and flows for an open PWR fuel cycle option using high values for ore and enrichment costs (all costs and flows annualized).....

A-2. Equilibrium fuel cycle material balance and flows for a PWR partial recycle option using high values for ore and enrichment costs (all costs and flows annualized; credit for MOX and RU fuel assemblies). 
A-3. Equilibrium fuel cycle material balance and flows for a PWR partial recycle option using high values for ore and enrichment costs (all costs and flows annualized; credit for MOX fuel assemblies; REPU discarded)

B-1. The accumulated (integrated) heavy metal mass in U.S. discharged fuel ..................... 43

B-2. Average discharge burnup of U.S. spent nuclear fuel ................................................ 44

B-3. Annual heavy metal mass in U.S. discharged fuel ................................................... 44

B-4. Distribution of PWR assemblies by initial enrichment. ............................................... 45

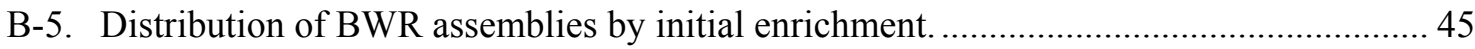

B-6. Comparison of PWR and BWR distributions of discharge burnup. ............................... 46 


\section{LIST OF TABLES}

Table

Page

1. Elements for which the combined mass shall not exceed $300 \mu \mathrm{g} / \mathrm{g} \mathrm{U}$............................5

2. Maximum impurity levels for selected elements .................................................... 5

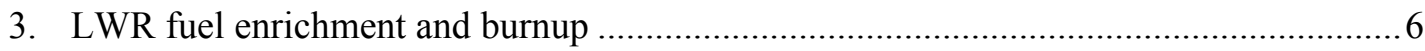

4. Results for multiple reenrichments of uranium for a scenario of PWR reactors

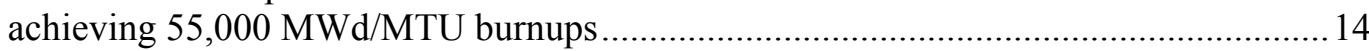

5. Results for multiple reenrichments of uranium for a scenario of PWR reactors

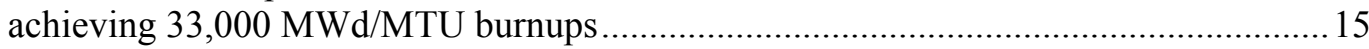

6. Results for multiple reenrichments of uranium for a scenario of PWR reactors achieving 33,000 and 55,000 MWd/MTU burnups, reactor pass 1 ................................ 16

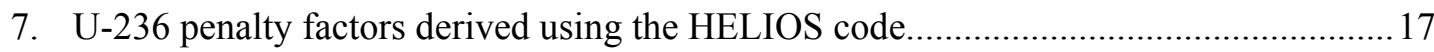

8. Results of the Doppler Temperature Coefficient and the Moderator Temperature Coefficient for Multiple Reenrichments of Uranium for a Scenario of PWR Reactors at a Burnup of 55,000 MWd/MTIHM ........................................................... 17

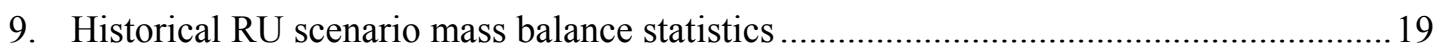

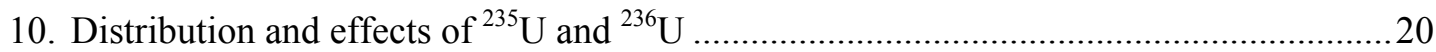

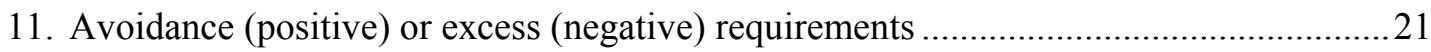

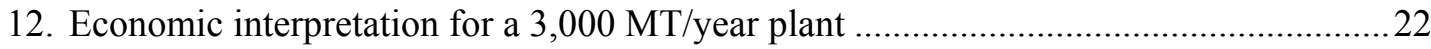

13. CANDU performance as function of ${ }^{236} \mathrm{U}$ concentration in RU ....................................2

14. CANDU performance as function of ${ }^{235} \mathrm{U}$ concentration in $\mathrm{RU}$ for $0.20 \mathrm{wt} \%{ }^{236} \mathrm{U}$ 28

15. CANDU performance as function of ${ }^{235} \mathrm{U}$ concentration in $\mathrm{RU}$ for $0.46 \mathrm{wt} \%{ }^{236} \mathrm{U}$ .28

16. Comparison of CANDU unit fuel costs from reprocessed and virgin uranium .................30

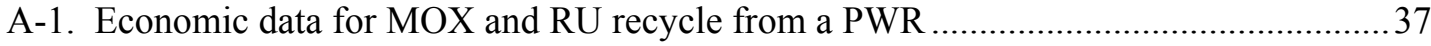





\section{ACRONYMS AND ABBREVIATIONS}

\begin{tabular}{|c|c|}
\hline ACR & Advanced CANDU Reactor \\
\hline AECL & Atomic Energy of Canada Limited \\
\hline AFCI & Advanced Fuel Cycle Initiative \\
\hline ALWR & advanced light-water reactor \\
\hline ASTM & American Society for Testing and Materials \\
\hline AVLIS & atomic vapor laser isotope separation \\
\hline BNFL & British Nuclear Fuels plc \\
\hline BOL & beginning of life \\
\hline BWR & boiling-water reactor \\
\hline CANDU & Canada Deuterium Uranium (Reactor) \\
\hline CANFLEX & CANDU Flexible \\
\hline CSNC & Canadian Nuclear Safety Commission \\
\hline CVR & coolant void reactivity \\
\hline D\&D & decontamination and decommissioning \\
\hline $\mathrm{DUO}_{2}$ & depleted uranium dioxide \\
\hline EOL & end of life \\
\hline ES\&H & environment, safety, and health \\
\hline EU & enriched uranium \\
\hline GNEP & Global Nuclear Energy Partnership \\
\hline $\mathrm{HE}$ & heavy element \\
\hline HEU & highly enriched uranium \\
\hline HM & heavy metal \\
\hline HWR & heavy-water reactor \\
\hline IAEA & International Atomic Energy Agency \\
\hline ILW & intermediate-level waste \\
\hline KAERI & Korea Atomic Energy Research Institute \\
\hline LES & Louisiana Energy Services \\
\hline LEU & low-enriched uranium \\
\hline LLW & low-level waste \\
\hline LUEC & levelized unit electricity cost \\
\hline LWR & light-water reactor \\
\hline MLIS & molecular laser isotope separation \\
\hline MOX & mixed oxide \\
\hline MT & metric ton $(\mathrm{s})$ \\
\hline MTIHM & metric ton(s) of initial heavy metal \\
\hline MTU & metric ton(s) of uranium \\
\hline MT-SWU & metric ton(s) separative work unit \\
\hline NDA & nondestructive assay \\
\hline NEA & Nuclear Energy Agency \\
\hline NRC & Nuclear Regulatory Commission \\
\hline NEF & National Enrichment Facility \\
\hline O\&M & operation and maintenance \\
\hline ORNL & Oak Ridge National Laboratory \\
\hline PHWR & pressurized-heavy-water reactor \\
\hline PUREX & plutonium-uranium extraction \\
\hline PWR & pressurized-water reactor \\
\hline
\end{tabular}


RU

RUFIC

SEU

SWU

TD

TRU

TVA

UNH

USEC reprocessed uranium

Recovered Uranium Fuel in CANDU

slightly enriched uranium

separative work unit

theoretical density

transuranic(s)

Tennessee Valley Authority

uranium nitrate hexahydride

United States Enrichment Corporation 


\section{EXECUTIVE SUMMARY}

\section{Introduction}

This report provides an analysis of the factors involved in the reuse of uranium recovered from commercial light-water-reactor (LWR) spent fuels (1) by reenrichment and recycling as fuel to LWRs and/or (2) by recycling directly as fuel to heavy-water-reactors (HWRs), such as the CANDU (registered trade name for the Canadian Deuterium Uranium Reactor). Reuse is an attractive alternative to the current Advanced Fuel Cycle Initiative (AFCI) Global Nuclear Energy Partnership (GNEP) baseline plan, which stores the reprocessed uranium (RU) for an uncertain future or attempts to dispose of it as "greater-than-Class C" waste. Considering that the open fuel cycle currently deployed in the United States already creates a huge excess quantity of depleted uranium, the closed fuel cycle should enable the recycle of the major components of spent fuel, such as the uranium and the hazardous, long-lived transuranic (TRU) actinides, as well as the managed disposal of fission product wastes.

Compared with the GNEP baseline scenario, the reuse of RU in the uranium fuel cycle has a number of potential advantages: (1) avoidance of purchase costs of $11-20 \%$ of the natural uranium feed; (2) avoidance of disposal costs for a large majority of the volume of spent fuel that is reprocessed; (3) avoidance of disposal costs for a portion of the depleted uranium from the enrichment step; (4) depending on the ${ }^{235} \mathrm{U}$ assay of the RU, possible avoidance of separative work costs; and (5) a significant increase in the production of ${ }^{238} \mathrm{Pu}$ due to the presence of ${ }^{236} \mathrm{U}$, which benefits somewhat the transmutation value of the plutonium and also provides some proliferation resistance.

\section{Reenrichment Option}

The reenrichment scenario assumes that the spent fuel from one reactor pass is reprocessed into oxide, converted to $\mathrm{UF}_{6}$, and used as enrichment feed along with sufficient natural-assay $\mathrm{UF}_{6}$ feed to produce the required enrichment product to fuel the next reactor pass.

The disadvantages generally attributed to the process of reenrichment include the presence of trace levels of TRU and fission products (especially technetium), the presence of ${ }^{236} \mathrm{U}$, and elevated levels of ${ }^{234} \mathrm{U}$. Some of the hesitancy to use RU derives from the nature of the gaseous diffusion enrichment technology and the fact that past uranium streams were not purified to GNEP-planned levels. In particular, present GNEP separations include near complete removal of technetium from the uranium stream.

Fortunately, by the estimated time a reprocessing plant will be in operation (i.e., 2025), both the United States Enrichment Corporation (USEC), the Louisiana Energy Services (LES)/National Enrichment Facility (NEF), and AREVA (Eagle Rock Enrichment Facility, Idaho Falls, ID) plan to have gas centrifuge facilities online in the United States. Compared with the present Paducah Gaseous Diffusion Plant, production-scale gas centrifuge cascades typically have an extremely small inventory in a full-enrichment cascade. GE-Hitachi also plan to have a laser-based commercial enrichment facility operating in Wilmington, $\mathrm{NC}$ by this time.

Planned GNEP separations, coupled with standard oxide-to-fluoride conversion processes (as presently implemented industrially), will meet American Society for Testing and Materials (ASTM) standards for the reenriched product and eliminate most of the problems experienced in the past.

Uranium-232 radiation creates problems with a nondestructive assay (NDA) in enrichment plants (interfering with ${ }^{235} \mathrm{U}$-deposit detection, at least when 1980 s technology is used). The ${ }^{232} \mathrm{U}$ specification has been set accordingly, and its concentration in low-enriched uranium (LEU) is so low that it has no appreciable effect in the reactor. Residues from ${ }^{232} \mathrm{U}$ daughters may introduce some chronic radiological problems on storage containers. However, these problems should be 
easily controllable by periodic maintenance. The ASTM limit for ${ }^{232} \mathrm{U}$ in reprocessed $\mathrm{UF}_{6}$ feed is $0.005 \mu \mathrm{g} / \mathrm{g}$ U. In the defined RU-reuse scenario, the RU is fed along with sufficient natural uranium to produce the required amount of product to feed the next reactor pass. Per our HELIOS calculations, the ${ }^{232} \mathrm{U}$ in the RU feed fraction exceeds the ASTM limit after the second reactor pass, but the combined feed does not.

Uranium-234 concentrations in the enriched uranium product are typically $0.040 \mathrm{wt} \%$ for an enrichment of $4.50 \mathrm{wt} \%{ }^{235} \mathrm{U}$ and $0.027 \mathrm{wt} \%$ for an enrichment of $3.00 \mathrm{wt} \%{ }^{235} \mathrm{U}$. For the case of $55,000 \mathrm{MWd} / \mathrm{MTIHM}$ and no RU (first reactor pass), the ${ }^{234} \mathrm{U}$ concentration is typically $0.020 \mathrm{wt} \%$ after 5 years' decay following fuel discharge and $0.030 \mathrm{wt} \%$ after 50 years' decay. For the second reactor pass (with RU), the concentrations of ${ }^{234} \mathrm{U}$ are $0.028 \mathrm{wt} \%$ (5 years' decay) and $0.042 \mathrm{wt} \%$ (50 years' decay). These values are below the ASTM limit for $\mathrm{UF}_{6}$ feed of $480 \mu \mathrm{g} / \mathrm{g} \mathrm{U}$ $(0.048$ wt \%).

Uranium-236, a mostly nonfissioning neutron absorber [in a typical pressurized-water- reactor (PWR) spectrum, about $5 \%$ of the captures by ${ }^{236} \mathrm{U}$ result in fissions], imposes a reactivity penalty on fuel, leading to a so-called ${ }^{236} \mathrm{U}$ penalty, generally expressed as an increase in ${ }^{235} \mathrm{U}$ enrichment required to compensate for the level of ${ }^{236} U$ present. Analyses considering enrichment of RU have generally assumed that only RU is fed (i.e., no natural uranium); therefore, the ${ }^{236} \mathrm{U}$ penalty could require a large increase in ${ }^{235} \mathrm{U}$. In the scenarios presented here, we do not consider all-RU enrichment; consequently, the resulting penalty is relatively small, requiring only an additional 0.05 to $0.15 \mathrm{wt} \%{ }^{235} \mathrm{U}$ (e.g., $4.55 \mathrm{vs} 4.5 \mathrm{wt} \%$ ) or an early removal of about 1 month on a schedule of three 18 month cycles. The recently granted Nuclear Regulatory Commission (NRC) license for the planned USEC centrifuge plant allows product up to $10 \%$, thus, the present $5 \%$ license limitation will no longer be a barrier.

Neutronic calculations showed that the rate of increase of ${ }^{236} U$ at discharge slows down with the increased number of reactor passes. After approximately seven reactor passes, the ${ }^{236} \mathrm{U}$ content in the enriched product almost reaches an asymptotic constant value of $0.84 \mathrm{wt} \%$, requiring an additional ${ }^{235} \mathrm{U}$ enrichment of $0.2 \mathrm{wt} \%$. The ${ }^{236} \mathrm{U}$ content of the combined feed and the ${ }^{236} \mathrm{U}$ content in the RU feed for the second reactor pass are below the ASTM RU feed limit of 8,400 $\mu \mathrm{g} / \mathrm{g}$. Accordingly, all RU under formal consideration should be well within the ASTM enrichment feed specification in all categories.

A particular consideration is the economic viability of the reuse of reprocessed uranium and the effect of minor isotopes, especially ${ }^{236} \mathrm{U}$, on the resulting reactor fuel. In the economic evaluation, the only factors considered are those that differ between the scenario and the GNEP baseline. For example, since both the baseline and alternate scenarios assume that spent fuel is reprocessed, the cost of reprocessing per se will be essentially the same and thus will be neglected. As indicated, it is assumed that the spent fuel from a reactor pass is reprocessed into oxide, converted to $\mathrm{UF}_{6}$, and used as enrichment feed along with sufficient natural-assay $\mathrm{UF}_{6}$ feed to produce the required enrichment product to fuel the next reactor pass. Several categories of spent fuel are considered representative of the distribution of assays and burnup levels in the present U.S. spent fuel inventory. Separative work unit (SWU) and natural uranium feed are calculated for these fuel categories and compared with an equivalent all-natural-feed scenario. An independent analysis, shown as an appendix, using the so-

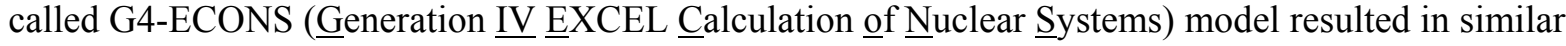
positive results.

\section{Conclusions Regarding the Reenrichment Option}

Several scenarios involving recycle of RU into the U.S. fuel cycle were evaluated. All involve use of RU at about the same rate that spent fuel is expected to be generated [i.e., RU replaces a small fraction of natural feed used in uranium enrichment ( $\sim 18 \%$ for $3 \mathrm{wt} \%$ assay fuel, $\sim 12 \%$ for $4.5 \mathrm{wt} \%$ assay fuel)]; however, the balance of enrichment feed is natural uranium. The primary penalty 
associated with the use of RU is the presence of ${ }^{236} \mathrm{U}$, which is assumed to impose a neutronic reactivity penalty that must be overcome by additional enrichment in ${ }^{235} \mathrm{U}$. Calculations run in this study determined this penalty factor for most of the scenarios considered. The values fall within (and at the lower end of) the range of values reported in earlier studies. Penalty factors for ${ }^{236} \mathrm{U}$ are dependent on details of the reactor scenario. No attempt was made to optimize the scenarios to minimize the penalty. Some modest reduction could likely be achieved were this warranted.

Within the limits of the scope of the analysis, all scenarios considered for PWR fuel, reuse of RU appears to be an economically favorable proposition (relative to disposal of the RU) - both at the present peak SWU and uranium prices and for more-typical average historical prices. Boiling-waterreactor (BWR) fuel was not explicitly analyzed, given the limited scope of this preliminary analysis. Several factors were not explicitly included in the analysis because of the present uncertainty regarding their costs, such as the cost of disposal of RU (should RU not be reused in the fuel cycle) and the savings for disposing of smaller quantities of enrichment tails. Including these factors would benefit the RU-reuse case, and the savings could be quite significant. These factors were omitted from the economic analysis to obtain a less biased result.

\section{CANDU Options and Conclusions}

Because ${ }^{235} U$ content in RU exceeds that of natural uranium, CANDU reactors can utilize RU fuel directly, without the expense and complexity of reenrichment. However, the use of RU fuel in Canadian CANDU reactor units will require extensive licensing and safety assessment processes with the regulatory authority, the Canadian Nuclear Safety Commission (CNSC). Nevertheless, there are many advantages that would make the effort to obtain regulatory approval worthwhile.

One advantage is that the higher-than-natural enrichment of RU may allow use of some of the excess reactivity from the RU fuel to offset fuel design options incorporated to reduce coolant void reactivity (CVR). These measures usually require the use of rare earth oxides (such as dysprosia) in the central fuel elements of the CANDU fuel bundles, which imposes a reactivity penalty. Also, if the RU fuel contains more fission products than planned (depending on the processing procedure), the excess reactivity resulting from the RU enrichment can offset the neutron poisoning effect and still result in a higher discharge burnup value for the fuel. However, it is expected that RU fuel in CANDU applications would increase average exit fuel burnup from nominally $7.5 \mathrm{MWd} / \mathrm{MTIHM}$ to approximately $10 \mathrm{MWd} / \mathrm{MTIHM}$.

A typical CANDU 6 reactor with natural uranium oxide fuel will use approximately 5,200 fuel bundles per year, or about 100 metric tons (MT) of natural uranium per year. Depending on the specific CANDU nuclear power plants and their fuel cycles, the CANDU fleet in Canada could use approximately 2,000 to 2,800 MT of RU per year.

The RU fuel cycle in the CANDU reactor would extract at least $25 \%$ more energy from the mined uranium than would be extracted for the same feed entering the LWR fuel cycle. Considering reenrichment of the RU for use in LWR, about twice as much energy can be extracted without reenrichment when utilized in a CANDU nuclear power plant. Another important consideration is that the uranium feed for CANDU fuel may not require the same stringent levels of purification required for reenrichment feed. 



\section{INTRODUCTION}

\subsection{OBJECTIVE}

This report provides an analysis of the factors involved in reusing reprocessed uranium (RU) recovered from commercial LWR spent fuels (1) by reenrichment and recycling as fuel to LWRs and/or (2) by recycling directly as fuel to heavy-water reactors (HWRs), such as the CANDU (registered trade name for the Canadian Deuterium Reactor). Reuse is an attractive alternative to the current Advanced Fuel Cycle Initiative (AFCI) Global Nuclear Energy Partnership (GNEP) baseline plan, which stores the RU for an uncertain future or attempts to dispose of it as "greater-than-Class C" waste. Considering that the open fuel cycle currently deployed in the United States already creates a huge excess quantity of depleted uranium, the closed fuel cycle is being considered as an alternative to enable recycle of the major components of spent fuel, such as the uranium and the hazardous, longlived transuranic (TRU) actinides, as well as the managed disposal of fission product wastes.

Compared with the GNEP baseline scenario, the reuse of RU in the uranium fuel cycle has a number of potential advantages: (1) avoidance of purchase costs of $11-20 \%$ of the natural uranium feed; (2) avoidance of disposal costs for a large majority of the volume of spent fuel that is reprocessed; (3) avoidance of disposal costs for a portion of the depleted uranium from the enrichment step; (4) depending on the ${ }^{235} \mathrm{U}$ assay of the RU, possible avoidance of separative work costs; and (5) a significant increase in the production of ${ }^{238} \mathrm{Pu}$ resulting from the presence of ${ }^{236} \mathrm{U}$, which benefits somewhat the transmutation value of the plutonium and also provides some additional proliferation resistance.

\subsection{HISTORY}

The uranium component of spent fuel is the largest, representing $\sim 66 \%$ of the total mass and $\sim 95 \%$ of the residual fuel (Fig. 1).

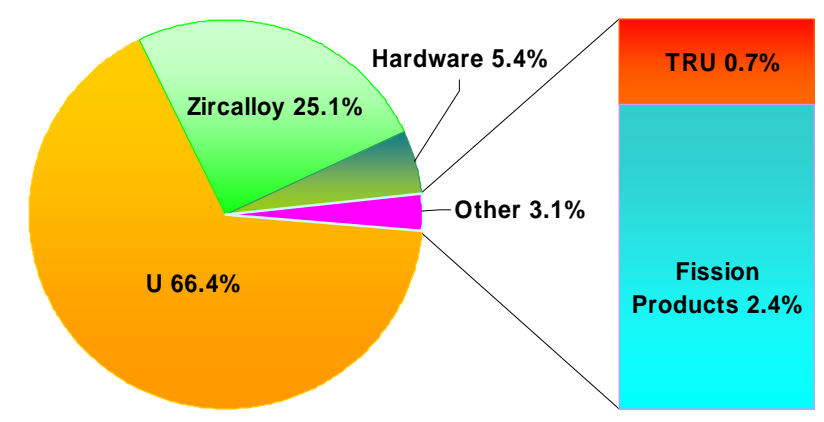

Fig. 1. Average composition of the U.S. spent fuel currently in storage at the reactor sites.

Only a small amount of the recovered uranium will be used as part of the transmutation fuels. As a result, alternative uses for the bulk of the uranium stream will have to be developed. Alternatively, the uranium could be stored for future applications (as in the baseline) or be disposed of as waste. The disposal path for uranium, even if purified to a level comparable with that of low level Class C waste, is uncertain. 
The concentration of residual fissile ${ }^{235} \mathrm{U}$ in the spent fuel is in the range of 0.8 to $1.3 \mathrm{wt} \%$, depending on initial fuel enrichment, irradiation neutron flux level and fuel burnup level at discharge. Other significant uranium isotope concentrations include ${ }^{232} \mathrm{U}(<5 \mathrm{ng} / \mathrm{g} \mathrm{U}),{ }^{234} \mathrm{U}(0.02$ to $0.04 \mathrm{wt} \%)$, and ${ }^{236} \mathrm{U}(0.3$ to $0.7 \mathrm{wt} \%)$.

The inventory of LWR spent fuel stored at the reactor sites across the United States is presently about 58,000 metric tons of uranium (MTU) and the accumulation rate is about 2,200 metric tons (MT) per year. Assuming that the commercial reprocessing plant begins operations around the year 2025, the inventory should have reached or exceeded 100,000 MT in the United States alone. As a consequence, a reprocessing plant could be fully devoted to work on the accumulated inventory for the life of the plant (e.g., 30 years).

Several recently published studies have considered the reuse of RU. A 1994 study by the Nuclear Energy Agency (NEA) [1] presented an economic evaluation of the nuclear fuel cycle from the point of view of impact on electricity cost. One comparison was between the reprocessing and reuse of RU and plutonium with that of direct disposal of spent fuel. The analysis used a discounted-cash-flow methodology. The study concluded that the reprocessing option would be slightly more expensive than the direct disposal option. Bunn et al. [2] published an economic evaluation beginning at the point of fuel discharge and compared the option of reprocessing and reuse with that of direct disposal of spent fuel. Like the NEA study, this was a discounted-present-value study, and, as in the former study, it concludes that reprocessing and reuse was more costly than direct disposal. A very recent report published by the International Atomic Energy Agency (IAEA) [3] comments on the major factors affecting such a technology strategy without actually drawing specific conclusions on economics. One cogent point made was that the economics depend strongly on the point of view of the entity making the decision (i.e., the costs and risks to that specific entity). When costs of disposal are part of the analysis, the cost uncertainty can be very large. Bunn [2], in particular, incorporated a fairly thorough analysis of cost uncertainty in his paper, but dismissed the risk that certain analyzed options would be unavailable (e.g., the risk that repository capacity would not be available for the quantity of spent fuel requiring direct disposal).

\subsection{SCOPE}

This report examines, for each of the proposed methods of reuse of the RU, the technical effects of the presence of elemental impurities and the various isotopes of uranium. Moreover, the economic factors that affect the reuse are identified, and an economic analysis is made for each of the reuse methods, leading to conclusions regarding the viability of deployment of the reuse methods.

\section{REENRICHMENT AND RECYCLE INTO LWRS}

\subsection{INTRODUCTION}

The reuse scenarios assume that the uranium in spent fuel from one reactor pass is reprocessed into oxide, converted to $\mathrm{UF}_{6}$, and used as enrichment feed along with sufficient natural-assay $\mathrm{UF}_{6}$ feed to produce the required enrichment product to fuel the next reactor pass. This is not the only RUreuse strategy possible. Others include blending with highly enriched uranium (HEU) to the desired assay, reenriching all-RU feed and using it in a small fraction of the reactor fleet, or reenriching allRU feed and using some RU-derived fuel rods with natural-uranium-derived fuel rods. Blending RU with HEU is a strategy currently used by several European countries.

Four sets of calculations will be presented and discussed. The first, addressing the use of RU from the existing U.S. inventory of spent fuel, examines the economic value of three selected categories of RU - roughly corresponding to low-, medium-, and high-burnup spent fuel. For this calculation set, only the first RU reactor pass is considered, because the reprocessing plant under consideration could 
operate with first-tier fuel for the life of the plant. The remaining calculation sets follow fuel through three reactor passes. The three sets differ in enrichment, burnup, and cooling.

In the economic evaluation, only those factors that differ between the RU-reuse scenario and a no-RU-reuse baseline scenario are considered. For example, because both the baseline and alternate scenarios assume that spent fuel is reprocessed, the cost of reprocessing will be essentially the same and thus will be neglected. As this evaluation shows, reenrichment appears to be economically viable for all spent LWR fuels.

A particular consideration is the economic viability of the reuse of recycled uranium and the effect of minor isotopes, especially ${ }^{236} \mathrm{U}$, on the resulting reactor fuel. Uranium-236, a mostly nonfissioning neutron absorber [in a typical pressurized-water reactor (PWR) spectrum, about 5\% of the captures by ${ }^{236} \mathrm{U}$ result in fissions], imposes a reactivity penalty on fuel, leading to a so-called ${ }^{236} \mathrm{U}$ penalty, generally expressed as the increase in ${ }^{235} \mathrm{U}$ enrichment required to compensate for the level of ${ }^{236} \mathrm{U}$ present. Since penalty factors vary from one report to another $[1,3,4]$ and were generally derived for fuel enrichments considerably lower (i.e., $\sim 3 \%$ ) than those popular at present $(>4 \%)$, we carried out neutronics calculations to derive values for our scenarios.

RU has been reused in the uranium fuel cycle in past years in the United States, and it is presently being reused in Europe [3]. The American Society for Testing and Materials (ASTM) specifications for enrichment feed and product explicitly consider the use of RU and contain specifications for RU that are readily achievable in a reprocessing operation. There appear to be no significant technical barriers from $\mathrm{UF}_{6}$ producers [5], enrichers [6], or utilities [7] to the use of fuel derived partially from RU. However, some issues need to be analyzed, in particular the actual effects that impurities may introduce enriching and reactor operations, as well as the customer's perception of those effects. For example, the companies operating $\mathrm{UF}_{6}$ conversion facilities and enrichment facilities would probably want to utilize separate, independent production lines for RU-derived and all-natural-uranium-derived product. In addition, the private sector is sensitive to financial risks that could arise from major government policy changes.

Compared with the GNEP baseline scenario, the reuse of RU in the uranium fuel cycle has a number of potential advantages: (1) avoidance of purchase costs of $11-20 \%$ of the natural uranium feed; (2) avoidance of disposal costs for a large majority of the volume of spent fuel that is reprocessed; (3) avoidance of disposal costs for a portion of the depleted uranium from the enrichment step; (4) depending on the ${ }^{235} \mathrm{U}$ assay of the RU, possible avoidance of separative work costs; and (5) as will be shown, a significant increase in the production of ${ }^{238} \mathrm{Pu}$ resulting from the presence of ${ }^{236} \mathrm{U}$, which benefits somewhat the transmutation value of the plutonium but also provides some additional proliferation resistance.

Disadvantages generally cited include presence of trace levels of TRU and fission products (especially technetium), presence of ${ }^{236} \mathrm{U}$, and elevated levels of ${ }^{234} \mathrm{U}$. Some of the hesitancy to use RU derives from past experiences attributable to the nature of the existing uranium enrichment technology in the United States (gaseous diffusion) and also to the fact that RU-derived $\mathrm{UF}_{6}$ manufactured in the past was not purified to the GNEP-planned levels of purification. In particular, GNEP separations include near-complete removal of technetium from the uranium stream.

The inventory and equilibrium times in the United States Enrichment Corporation (USEC) Gaseous Diffusion Plant at Paducah, Kentucky, are sufficiently large that it is impossible to provide an exact correlation between a particular customer's feed and the enriched product that a specific customer receives. While one customer may want to provide RU feed and be perfectly willing to receive a product with the minor isotopes typical of RU present, another who provides all-natural feed may be very reluctant to accept such a product. The diffusion plant is, however, not capable of isolating these two hypothetical enrichment streams, except with the introduction of impractically long transition periods between operations in RU and non-RU modes.

Fortunately, by the estimated time a reprocessing plant will be in operation (i.e., 2025), both USEC, Louisiana Energy Services (LES)/National Enrichment Facility (NEF), and AREVA intend to have gas centrifuge facilities online in the United States. GE-Hitachi also plans to have a laser-based commercial enrichment facility operating in Wilmington, NC by this time. Production-scale gas centrifuge cascades typically have an extremely small inventory in a full-enrichment cascade compared with the present Paducah Gaseous Diffusion Plant. Throughput in a gas centrifuge plant is 
achieved by operating several parallel cascades that can easily operate relatively independently. One segment of the plant could be dedicated to enrichment involving RU feed, while another segment could utilize only natural feed, introducing no possibility of cross-contamination between the two segments.

\subsection{EFFECTS OF TRU ELEMENTS AND FISSION PRODUCTS ON RU}

RU may contain undesirable impurities presently available, but technology can remove them to acceptable levels. Several ASTM specifications govern the allowed levels of uranium and RU at various points in the fuel cycle, including levels in uranyl nitrate solution used for oxide production [8], $\mathrm{UF}_{6}$ enrichment feed [9], $\mathrm{UF}_{6}$ enrichment product [10], and oxides used for fuel manufacture [1113]. In fact, the specifications are agreed upon by representatives of the industries involved in these processes and are achievable with current technology. Few elements will follow uranium through the many physical and chemical processes involved. Thus, the main concern is with minor isotopes of uranium; TRU elements; and a few fission products, most notably technetium.

The presence of trace levels of TRU and fission products, especially technetium, is not a technological issue but instead is an economic issue related to the cost of purification of the uranium stream to the desired level during the processing of the spent fuel. The reprocessing plant is expected to provide the bulk of the purification; however, some extra purification could be performed after fluorination to $\mathrm{UF}_{6}$ (e.g., technetium trapping by $\mathrm{MgF}_{2}$ ).

The technetium in $\mathrm{RU} \mathrm{UF}_{6}$ will be primarily in the form of $\mathrm{TcO}_{3} \mathrm{~F}$, a species with some volatility and a strong propensity to adsorb on surfaces. Since $\mathrm{TcO}_{3} \mathrm{~F}$ has about half the mass of $\mathrm{UF}_{6}$, it will separate to the product stream in either the gaseous diffusion or the gas centrifuge process. Its propensity to adsorption will delay its progress through the cascade compared with that for a pure gas, this delay likely being much more pronounced in the inherently high-surface-area, high-inventory gaseous diffusion process. In the centrifuge process, at each stage, some technetium may escape the centrifuge rotor to the vacuum casing. The maximum allowed level of ${ }^{99} \mathrm{Tc}$ in RU feed is $0.5 \mathrm{ppm}(0.5$ $\left.\mu \mathrm{g}^{99} \mathrm{Tc} / \mathrm{g} \mathrm{U}\right)$.

Because technetium in the feed eventually finds its way to the product stream, the enricher would be reluctant to feed much RU at this maximum level. Instead, the RU would be subjected to purification to achieve levels closer to the natural-feed technetium specification of $0.01 \mu \mathrm{g}{ }^{99} \mathrm{Tc} / \mathrm{g} \mathrm{U}$ (unless a customer waived the product specification). Technology presently in use is capable of achieving these lower levels.

According to ASTM standards [9], the total alpha activity from neptunium and plutonium in the reprocessed $\mathrm{UF}_{6}$ supplied as feed to an enrichment facility shall be limited to $25,000 \mathrm{~Bq} / \mathrm{kg} \mathrm{U}$ $\left(1.5 \times 10^{6} \mathrm{dpm} / \mathrm{kg} \mathrm{U}\right)$. Per ASTM standards, the total gamma radiation from fission products shall not exceed $1.1 \times 10^{5} \mathrm{MeV} / \mathrm{s}-\mathrm{kg} \mathrm{U}$.

Table 1 lists the elements that form nonvolatile fluorides. The combined total of these elements shall not exceed $300 \mu \mathrm{g} / \mathrm{g}$ U. As previously noted, reprocessing and oxide-to-fluoride conversion processes, as presently implemented industrially, meet these specifications. 
Table 1. Elements for which the combined mass shall not exceed $300 \mu \mathrm{g} / \mathrm{g} \mathrm{U}$

\begin{tabular}{ll}
\hline Aluminum & Manganese \\
Barium & Nickel \\
Beryllium & Potassium \\
Bismuth & Silver \\
Cadmium & Sodium \\
Calcium & Strontium \\
Chromium & Thorium \\
Copper & Tin \\
Iron & Zinc \\
Lithium & Zirconium \\
Magnesium & \\
\hline \multicolumn{2}{c}{ Source: ASTM Spec C-787-96 [ref. 9]. }
\end{tabular}

Table 2 shows the maximum impurity levels for several elements that are volatile or that form volatile fluorides.

Table 2. Maximum impurity levels for selected elements

\begin{tabular}{lc}
\hline Element & Limit $(\mu \mathrm{g} / \mathrm{g} \mathrm{U})$ \\
\hline Antimony & 1 \\
Arsenic & 3 \\
Boron & 1 \\
Bromine & 5 \\
Chlorine & 100 \\
Chromium & 10 \\
Molybdenum & 1.4 \\
Niobium & 1 \\
Phosphorus & 50 \\
Ruthenium & 1 \\
Silicon & 100 \\
Tantalum & 1 \\
Titanium & 1 \\
Tungsten & 1.4 \\
Vanadium & 1.4 \\
\hline \multicolumn{1}{c}{ Source: ASTM Spec C-787-96 [ref. 9]. }
\end{tabular}

When reused today, recycled uranium that was reprocessed and converted to $\mathrm{UF}_{6}$ decades in the past is frequently found to have impurity levels above the current standards. However, this will not be a problem for the proposed new processing plant since the uranium stream will be purified to prevailing standards. 


\subsubsection{Considerations Regarding the Uranium Isotopes Present in RU}

\subsubsection{Uranium-235}

Spent fuel in the present inventory typically has assays above that of natural uranium. As shown in Table 3, a trend toward higher fuel burnups has been accomplished by using fuel with a higher initial ${ }^{235} \mathrm{U}$ assay. According to ORIGEN [14] and HELIOS [15] calculations, the assay of the uranium in the spent fuel is in all cases above natural assay; thus, the spent fuel already inherently contains some beneficial separative work relative to natural feed. However, it should be noted that even uranium with below-natural assays has commercial value if its assay is higher than the prevailing assay of enrichment tails. The choice of a tails assay is a balance between the cost of enrichment and the cost of feed. Frequently, higher-assay tails, generated when feed was inexpensive compared with separation costs, are refed to the enrichment plant when the cost balance shifts to make its use economical.

Table 3. LWR fuel enrichment and burnup ${ }^{a}$

\begin{tabular}{ccccc}
\hline LWR fuel & Year fuel is loaded & $\begin{array}{c}\text { Enrichment } \\
\left(\%{ }^{235} \mathrm{U}\right)\end{array}$ & $\begin{array}{c}\text { Design burnup } \\
(\mathrm{MWd} / \mathrm{MTIHM})\end{array}$ & $\begin{array}{c}\text { Actual burnup } \\
(\mathrm{MWd} / \mathrm{MTIHM})\end{array}$ \\
\hline BWR & 1993 & 3.14 & 36,000 & 31,000 \\
BWR & 1996 & 3.12 & 40,000 & 35,130 \\
BWR & 2000 & 3.47 & 43,000 & $b$ \\
BWR & 2010 & 3.58 & 46,000 & $b$ \\
& 1993 & & & 39,630 \\
PWR & 1997 & 3.84 & 42,000 & 40,000 \\
PWR & 2001 & 4.11 & 46,000 & $b$ \\
PWR & 4.38 & 50,000 & $b$ \\
PWR & 2008 & 5.74 & 55,000 &
\end{tabular}

\subsubsection{Uranium-232}

In power reactors running on an enriched ${ }^{235} \mathrm{U}$ fuel cycle, the isotope ${ }^{232} \mathrm{U}$ is produced predominantly from the alpha decay of ${ }^{236} \mathrm{Pu}$ (half-life 2.87 years). Plutonium-236 is formed via the beta decay of ${ }^{236} \mathrm{~Np}$, which is produced in a reactor via the $(\mathrm{n}, 2 \mathrm{n})$ or (gamma,n) reactions in ${ }^{237} \mathrm{~Np}$. The neutron capture in ${ }^{236} \mathrm{U}$ leads to the production of the short-lived ${ }^{237} \mathrm{U}$ isotope, which decays to the ${ }^{237} \mathrm{~Np}$ isotope. The production of ${ }^{232} \mathrm{U}$ is thus influenced by the concentration of ${ }^{236} \mathrm{U}$ in the fuel.

The isotope ${ }^{232} \mathrm{U}$ has no effect on the neutronic performance of a reactor core because of the very low concentration of ${ }^{232} \mathrm{U}$ in the fuel (typically less than $5.0 \times 10^{-9} \mathrm{~g}{ }^{232} \mathrm{U} / \mathrm{g} \mathrm{U}$ ). However, ${ }^{232} \mathrm{U}$ is radiologically the most important of the uranium isotopes, not because of ${ }^{232} \mathrm{U}$ itself, but because of the radiological hazard of the decay daughters of ${ }^{232} \mathrm{U}$.

Uranium-232 radiation creates a nondestructive assay (NDA) problem in enrichment plants (interfering with ${ }^{235} \mathrm{U}$-deposit detection, at least when 1980 s technology is used). The ${ }^{232} \mathrm{U}$ specification has been set accordingly, and its concentration in low-enriched uranium (LEU) is so low that it has no appreciable effect in the reactor. Residues from ${ }^{232} \mathrm{U}$ daughters may introduce some chronic radiological problems on storage containers that should be easily controllable by periodic maintenance. The ASTM limit for ${ }^{232} \mathrm{U}$ in reprocessed $U_{6}$ feed is $0.005 \mu \mathrm{g} / \mathrm{g} \mathrm{U}$. In the defined RUreuse scenario, the RU is fed along with sufficient natural uranium to produce the required amount of 
product to feed the next reactor pass. Per our HELIOS calculations, the ${ }^{232} U$ in the RU feed fraction exceeds the ASTM limit after the second reactor pass, but the combined feed does not.

\subsubsection{Uranium-234}

Uranium-234 is naturally occurring (with a concentration in natural uranium of typically $0.0055 \mathrm{wt} \%$, or $55 \mathrm{ppm}$ ) and is enriched along with ${ }^{235} \mathrm{U}$, at least for monotonic molecular-weightbased techniques, such as gaseous diffusion and gas centrifuge enrichment. This would not be the case with technologies operating on laser spectroscopic principles [atomic vapor laser isotope separation (AVLIS) or molecular laser isotope separation (MLIS)] or mass spectrometric principles (use of calutrons or the plasma separation process).

As discussed later in this report, the calculated concentration of ${ }^{234} U$ for the limiting burnup of $55,000 \mathrm{MWd} / \mathrm{MTIHM}$ is $300 \mu \mathrm{g} / \mathrm{g} \mathrm{U}$ after a decay of 50 years following fuel discharge. This value is below the ASTM limit for $\mathrm{UF}_{6}$ feed of $480 \mu \mathrm{g} / \mathrm{g}$ U. During reactor operation the neutron capture in ${ }^{234} \mathrm{U}$ creates ${ }^{235} \mathrm{U}$. The concentration of ${ }^{234} \mathrm{U}$ in the fuel will vary with burnup. Also, after the fuel is discharged, the concentration of ${ }^{234} \mathrm{U}$ will increase with decay time because of the alpha decay of ${ }^{238} \mathrm{Pu}$ (half-life of 87.7 years).

In Tables 4-6 (which appear at the end of Sect. 2.2.1.4) results are shown for the concentration of ${ }^{234} \mathrm{U}$ for multiple reenrichments of uranium for three reactor irradiation passes, each reactor pass achieving an average fuel burnup of 55,000 or $33,000 \mathrm{MWd} / \mathrm{MTIHM}$. The ${ }^{234} \mathrm{U}$ concentrations in the enriched uranium product are typically $0.040 \mathrm{wt} \%$ and $0.027 \mathrm{wt} \%$ for enrichments of $4.50 \mathrm{wt} \%$ and $3.00 \mathrm{wt} \%{ }^{235} \mathrm{U}$, respectively. For the case of 55,000 MWd/MTIHM and no RU (first reactor pass), the ${ }^{234} \mathrm{U}$ concentrations are typically $0.020 \mathrm{wt} \%$ after 5 years' decay following fuel discharge and $0.030 \mathrm{wt} \%$ after 50 years' decay. For the second reactor pass (with RU), the concentrations of ${ }^{234} \mathrm{U}$ are $0.021 \mathrm{wt} \%$ (5 years' decay) and $0.037 \mathrm{wt} \%$ (50 years' decay). These values are below the ASTM limit for $\mathrm{UF}_{6}$ feed of $480 \mu \mathrm{g} / \mathrm{g} \mathrm{U}(0.048 \mathrm{wt} \%)$.

\subsubsection{Uranium-236}

The ${ }^{236} \mathrm{U}$ isotope does not occur naturally but is formed by neutron capture in ${ }^{235} \mathrm{U}$. Using the uranium from reprocessed fuel as partial feed to a uranium enrichment plant will result in an initial ${ }^{236} \mathrm{U}$ content in the enriched product and thus act as an additional neutron poison in the reactor core. This isotope is enriched along with ${ }^{235} \mathrm{U}$ but to a lesser degree. (Again, this would not be the case for AVLIS.) When ${ }^{235} \mathrm{U}$ absorbs a neutron, the majority of the absorption reactions lead to the fission process of ${ }^{235} \mathrm{U}$, while a small amount of the absorption leads to the neutron capture in ${ }^{235} \mathrm{U}$. The production of ${ }^{236} \mathrm{U}$ in a reactor results primarily from this neutron capture process. The destruction of ${ }^{236} \mathrm{U}$ is largely attributable to the neutron capture in ${ }^{236} \mathrm{U}$, leading to the production of the short-lived ${ }^{237} \mathrm{U}$, which subsequently decays to ${ }^{237} \mathrm{~Np}$. Only about $5 \%$ of the captures by ${ }^{236} \mathrm{U}$ result in fissions. The neutron capture in ${ }^{237} \mathrm{~Np}$ leads to the production of the short-lived ${ }^{238} \mathrm{~Np}$, which then decays to ${ }^{238} \mathrm{Pu}$. In thermal reactors using LEU fuel, the production of ${ }^{236} \mathrm{U}$ is usually greater than its destruction by neutron capture and fission. The difference between production and destruction rates of ${ }^{236} \mathrm{U}$ decreases with higher concentrations of ${ }^{236} \mathrm{U}$ in the fuel and with increased fuel burnup. The production rate of ${ }^{236} \mathrm{U}$ decreases as a function of fuel cycle time because of the decreased concentration of ${ }^{235} \mathrm{U}$ that results from fuel burnup.

Because of the nonfission capture in ${ }^{236} \mathrm{U}$, the fuel at a given ${ }^{235} \mathrm{U}$ enrichment has a slightly lower neutronic reactivity when ${ }^{236} \mathrm{U}$ is present. This factor is immaterial early in the life of the fuel in the reactor, because burnable neutron poisons (e.g., Gd, Er, or B) and soluble boron are added to control the excess reactivity. However, the reactivity loss persists late in the life of the fuel assemblies. Consequently, the assemblies will have to be replaced earlier than would be the case for fuel free of ${ }^{236} \mathrm{U}$ or the initial enrichment will have to be slightly higher to compensate for the ${ }^{236} \mathrm{U}$ content.

The specific circumstances are definitely dependent on the fuel's history in the reactor. The analysis of this effect was calculated for some base cases in the 1970s for PWR and boiling-water reactor (BWR) fuel at the prevailing ${ }^{235} \mathrm{U}$ assays at that time (i.e., near $3 \%$ ). Those calculations showed that the initial presence of ${ }^{236} \mathrm{U}$ would result in the fuel decreasing to a particular neutronic reactivity level a bit earlier than for similar enriched fuel without ${ }^{236} \mathrm{U}$. Additional ${ }^{235} \mathrm{U}$ could compensate for this effect, which is termed the ${ }^{\text {"2236 }} \mathrm{U}$ penalty" or " ${ }^{236} \mathrm{U}$ compensation factor." The 
${ }^{236} \mathrm{U}$ compensation factors that were determined in the 1970 s and 1980 s in the U.S. enrichment industry range from 0.25 to 0.33 : that is, 0.25 to 0.33 units of additional ${ }^{235} \mathrm{U}$ to compensate for 1 unit of initial ${ }^{236} U$ in the reactor fuel [4]. Similar studies by the NEA [1] use a compensation factor of 0.28 , apparently derived from studies in the 1980s. A recent report by the IAEA [3] studied the use of RU in fuel with ${ }^{235} \mathrm{U}$ of assays ranging from 3.25 to $3.7 \%$. While the report does not explicitly state the compensation factor used (or derived), one can deduce a value of 0.24 from the results.

Analyses considering enrichment of RU have generally assumed that only RU is fed (i.e., no natural uranium); therefore, the effect of the ${ }^{236} \mathrm{U}$ penalty could be to require a large increase in ${ }^{235} \mathrm{U}$. When the desired (effective) product enrichment is near the limit of the enrichment facility's license, this could be prohibitive. In the scenarios presented here, we do not consider all-RU enrichment and thus resulting penalty is relatively small. In any case, gas centrifuge will likely be the process used for enrichment. The recently granted Nuclear Regulatory Commission (NRC) license for the planned USEC centrifuge plant allows product up to $10 \%$, in contrast to the $5 \%$ license at the gaseous diffusion plant.

Because the ${ }^{236} \mathrm{U}$ compensation factors used in the 1970 s to 1990 s were generally derived for the then-prevailing typical enrichments and fuel burnups, more recent fuel burnup calculations have been performed to determine the effect that today's higher-initial-enrichment/higher-burnup scenarios have on the ${ }^{236} \mathrm{U}$ compensation factors.

Detailed two-dimensional reactor-core lattice neutronic calculations were performed at Oak Ridge National Laboratory (ORNL) with the HELIOS computer code [15] using the 47-neutrongroup cross-section HELIOS library. In the reactor-core lattice neutronic calculations that were performed, each fuel assembly consisted of 264 cylindrical fuel rods and 25 guide tubes that were arranged in a $17 \times 17$ square lattice. Each fuel assembly contained 264 active fuel rods. Cases for two different final average fuel burnups were studied: 55,000 MWd/MTIHM and 33,000

$\mathrm{MWd} / \mathrm{MTIHM}$. The initial ${ }^{235} \mathrm{U}$ enrichment of the fuel was taken to be $4.50 \mathrm{wt} \%$ for the cases with burnups of 55,000 MWd/MTIHM and $3.00 \mathrm{wt} \%$ for the cases with fuel burnups of 33,000 MWd/MTIHM.

A total of 104 fuel rods contained $\mathrm{UO}_{2}$ fuel pellets with a small amount of burnable poisons (e.g., zirconium boride, erbia, or gadolinia). In the present calculations, a concentration of $1.0 \mathrm{wt} \%$ natural erbium in uranium was used for the 55,000 MWd/MTIHM cases and $0.7 \mathrm{wt} \%$ natural erbium was used for the 33,000 MWd/MTIHM cases. The remaining 160 fuel rods contained $\mathrm{UO}_{2}$ fuel pellets with no burnable poisons. The fuel pellet density was taken to be $95.0 \%$ theoretical density (TD). The fuel assemblies were irradiated for three reactor fuel cycles (18 month cycles for 55,000 $\mathrm{MWd} / \mathrm{MTIHM}$ cases and 12 month cycles for 33,000 MWd/MTIHM cases) in a reactor core that contained 193 fuel assemblies. In each scenario the reactor was operated at a power level of 3,400 MW(t). The fuel pellet diameter was 0.325 in., the Zircaloy- 4 clad thickness was 0.0225 in., and the active fuel height was 144 in. Standard PWR operating fuel temperatures and water coolant conditions were used in the calculations for the reactor fuel cycle.

A synopsis of the results of the neutronic calculations for several RU scenarios is displayed in Tables 4-6. Each table shows the results for three reactor passes. For the first reactor pass, the enriched uranium for the reactor fuel was produced in an enrichment plant (gaseous diffusion plant or centrifuge plant) using all-natural-uranium feed and a $0.20 \mathrm{wt} \%{ }^{235} \mathrm{U}$ tails assay. It was assumed that there would be a fleet of PWR reactors requiring 3,000 MTU of enriched fuel per year for the reactor loadings. The fuel was used in PWR reactors for three reactor fuel cycles. After a decay of 5 years (following fuel discharge), the fuel was assumed to be reprocessed and the resulting RU was used as additional feed into a uranium enrichment plant. Additional natural uranium feed was also fed to the enrichment plant, which was assumed to be operated with a $0.20 \mathrm{wt} \%{ }^{235} \mathrm{U}$ tails assay in order to produce 3,000 MTU of enriched uranium product per year. The enriched uranium product was used as fuel in a fleet of PWR reactors during a second reactor pass for three reactor fuel cycles. The third reactor pass is similar to the second, except that that the RU from the second pass is used as RU to the uranium enrichment plant for the production of enriched uranium product for the reactors in the third reactor pass.

Table 4 displays the results for multiple reenrichments of uranium for three reactor passes, each pass achieving an average fuel burnup of 55,000 MWd/MTIHM. In the first pass, the reactor fuel (for 
which the enriched uranium was produced in an enrichment plant using all-natural-uranium feed and a $0.20 \mathrm{wt} \%{ }^{235} \mathrm{U}$ tails assay), the following uranium isotopics were used: $0.040 \mathrm{wt} \%{ }^{234} \mathrm{U}, 4.50 \mathrm{wt} \%$ ${ }^{235} \mathrm{U}, 0.00 \mathrm{wt} \%{ }^{236} \mathrm{U}$, and $95.46 \mathrm{wt} \%{ }^{238} \mathrm{U}$. For an irradiation during three 18 month fuel cycles, a reactor capacity factor of $90 \%$, a fuel burnup of 55,000 MWd/MTIHM, and a decay time of 5 years following fuel discharge, the uranium isotopics were calculated to be $0.020 \mathrm{wt} \%{ }^{234} \mathrm{U}, 0.84 \mathrm{wt} \%$ ${ }^{235} \mathrm{U}, 0.69 \mathrm{wt} \%{ }^{236} \mathrm{U}$, and $98.45 \mathrm{wt} \%{ }^{238} \mathrm{U}$. Assuming a fleet of PWR reactors requiring 3,000 MTU of enriched uranium fuel per year, the total ${ }^{238} \mathrm{Pu}$ generation was $943 \mathrm{~kg}$ per year (following a decay of 5 years following fuel discharge). This first-pass calculation defines the composition of the spent fuel already in the inventory or of that to be added in the near future.

After a 5 year decay (following fuel discharge), the fuel was assumed to be reprocessed and the resulting RU was used as additional feed into a uranium enrichment plant. Additional natural feed was also fed to the enrichment plant, which was assumed to be operated with a $0.20 \mathrm{wt} \%{ }^{235} \mathrm{U}$ tails assay in order to produce 3,000 MTU per year of enriched uranium product. The enrichment product isotopics were calculated as follows: $0.054 \mathrm{wt} \%{ }^{234} \mathrm{U}, 4.494 \mathrm{wt} \%{ }^{235} \mathrm{U}, 0.372 \mathrm{wt} \%{ }^{236} \mathrm{U}$, and $94.98 \mathrm{wt} \%{ }^{238} \mathrm{U}$. The enriched uranium product was then used for a second reactor pass in the PWR reactor fleet that required 3,000 MTU loading per year. Using the same initial burnable poison concentration as in the first reactor pass, a fuel residence time of three 18 month fuel cycles, a capacity factor of $90 \%$, and an average burnup of 55,000 MWd/MTIHM, the discharged uranium isotopics (5 years following fuel discharge) were as follows: $0.028 \mathrm{wt} \%{ }^{234} \mathrm{U}, 0.888 \mathrm{wt} \%{ }^{235} \mathrm{U}$, $1.036 \mathrm{wt} \%{ }^{236} \mathrm{U}$, and $98.05 \mathrm{wt} \%{ }^{238} \mathrm{U}$. Assuming a fleet of PWR reactors requiring 3,000 MTU per year for its initial reactor loadings, the total ${ }^{238} \mathrm{Pu}$ generation $1,422 \mathrm{~kg}$ per year (after a decay of 5 years following fuel discharge), which represents an increase of approximately $50 \%$ over the case of the first pass (reactors with no RU). This increase in ${ }^{238} \mathrm{Pu}$ generation is caused by the higher initial content $(0.372 \mathrm{wt} \%)$ of ${ }^{236} \mathrm{U}$ in the uranium fuel.

Similarly for the third reactor pass, the total ${ }^{238} \mathrm{Pu}$ generation was $1,651 \mathrm{~kg}$, an increase of $16 \%$ over that for the second reactor pass. Note that the rate of increase of ${ }^{236} \mathrm{U}$ at discharge slows down as the number of reactor passes increases. The present neutronic calculations have shown that after approximately seven reactor passes, the ${ }^{236} U$ content in the spent fuel reaches an almost asymptotic constant value.

Table 5 displays the results for multiple reenrichments of uranium for three reactor passes, each pass achieving an average fuel burnup of $33,000 \mathrm{MWd} / \mathrm{MTIHM}$. Note that since the initial ${ }^{235} \mathrm{U}$ enrichment is smaller than for the cases at 55,000 MWd/MTIHM, and since the reactor fuel cycle lengths are shorter (12 months versus 18 months), the ${ }^{236} \mathrm{U}$ concentration at the end-of-life (EOL) of the fuel are smaller for the 33,000 MWd/MTIHM than for the 55,000 MWd/MTIHM cases. Consequently the ${ }^{238} \mathrm{Pu}$ production is also smaller.

Table 6 displays the results for multiple re-enrichments of uranium for three reactor passes, the first achieving an average fuel burnup of $33,000 \mathrm{MWd} / \mathrm{MTIHM}$. This scenario is comparable to that for spent fuel currently in storage ("old fuel"). After 50 years' decay following fuel discharge, the fuel was assumed to be reprocessed and the resulting RU was used as additional feed into a uranium enrichment plant. Additional natural feed was also fed to the enrichment plant in order to produce 3,000 MTU of enriched uranium product per year. The 3,000 MTU enriched uranium fuel was then used in the loading of PWR reactors in the second reactor pass, achieving an average fuel burnup of $55,000 \mathrm{MWd} / \mathrm{MTIHM}$. A decay time of 5 years after discharge is assumed for all passes after the first. The third reactor pass is similar to the second pass, achieving a target average fuel burnup of 55,000 MWd/MTIHM.

Figure 2 displays the concentration of ${ }^{236} \mathrm{U}$ in uranium in the enriched product as a function of the reactor pass number. The estimated asymptotic constant value of the ${ }^{236} \mathrm{U}$ concentration in uranium in the loaded enriched product is approximately $0.6 \mathrm{wt} \%$ for the $33,000 \mathrm{MWd} / \mathrm{MTIHM}$ cases. Figure 3 displays the additional ${ }^{235} \mathrm{U}$ in uranium required to compensate for the presence of ${ }^{236} \mathrm{U}$ in the loaded enriched product as a function of the reactor passes. The loaded ${ }^{236} U$ per $U$ concentrations are dependent on several factors: 
1. The production rate of ${ }^{236} \mathrm{U}$ in uranium as a function of burnup depends on the neutron capture process in ${ }^{235} \mathrm{U}$ and thus depends on the ${ }^{235} \mathrm{U}$ concentration. because the ${ }^{235} \mathrm{U}$ concentration decreases with increasing burnup, the ${ }^{236} \mathrm{U}$ production rate also decreases with burnup.

2. The destruction rate of ${ }^{236} U$ (i.e., the ${ }^{236} U$ produced by neutron captures in ${ }^{235} \mathrm{U}$ ) increases with the concentration of ${ }^{236} \mathrm{U}$ in uranium.

3. The destruction rate of ${ }^{236} \mathrm{U}$ (i.e., that present in the loaded enriched product) is proportional to the concentration of ${ }^{236} \mathrm{U}$ in uranium.

4. The results assume a separation behavior in the enrichment plant based on mass, such as gaseous diffusion or gas centrifuge enrichment, that will also concentrate ${ }^{234} U$ and ${ }^{236} U$ along with ${ }^{235} \mathrm{U}$. The tails enrichment was $0.2 \mathrm{wt} \%$. It should be noted that a fair fraction of the ${ }^{236} \mathrm{U}$ (about $35 \%$ for the $33,000 \mathrm{MWd} / \mathrm{MTIHM}$ cases and about $40 \%$ for the 55,000 $\mathrm{MWd} / \mathrm{MTIHM}$ cases) ends up in the enrichment tails.

Figure 4 displays the concentration of ${ }^{236} \mathrm{U}$ in uranium in the enriched uranium product as a function of the reactor pass numbers for this scenario, extended to 7 reactor passes. The estimated asymptotic constant value of the ${ }^{236} \mathrm{U}$ concentration in uranium in the loaded enriched product is approximately $0.84 \mathrm{wt} \%$. Figure 5 displays the additional ${ }^{235} \mathrm{U}$ in uranium required to compensate for the presence of ${ }^{236} \mathrm{U}$ in the loaded enriched product as a function of reactor passes. Uranium-232 was also tracked in this scenario. Figure 6 displays the concentration of ${ }^{232} \mathrm{U}$ in uranium in the loaded enriched product. Radiologically, ${ }^{232} \mathrm{U}$ is the most important of the uranium isotopes. Although the ${ }^{232} \mathrm{U}$ concentration in uranium reaches an estimated asymptotic value that exceeds the current ASTM limit of $0.005 \mu \mathrm{g} / \mathrm{g} \mathrm{U}$, the combined feed does not. The results assume a mass-separation behavior in the enrichment plant similar to that of gaseous diffusion or gas centrifuge enrichment that will also concentrate ${ }^{232} \mathrm{U},{ }^{233} \mathrm{U},{ }^{234} \mathrm{U}$, and ${ }^{236} \mathrm{U}$ - along with ${ }^{235} \mathrm{U}$. Interestingly, the weight percentages of the feed into the enriched product increase with decreasing uranium isotope mass numbers. For the second reactor pass enrichment, with a $4.5 \%$ effective ${ }^{235} \mathrm{U}$ assay and $0.2 \%$ tails assay, typical values are as follows: $98.5 \mathrm{wt} \%$ for ${ }^{232} \mathrm{U}, 96.3 \mathrm{wt} \%$ for ${ }^{233} \mathrm{U}, 89.2 \mathrm{wt} \%$ for ${ }^{234} \mathrm{U}, 75.6 \mathrm{wt} \%$ for ${ }^{235} \mathrm{U}$, and $57.2 \mathrm{wt} \%$ for ${ }^{236} \mathrm{U}$.

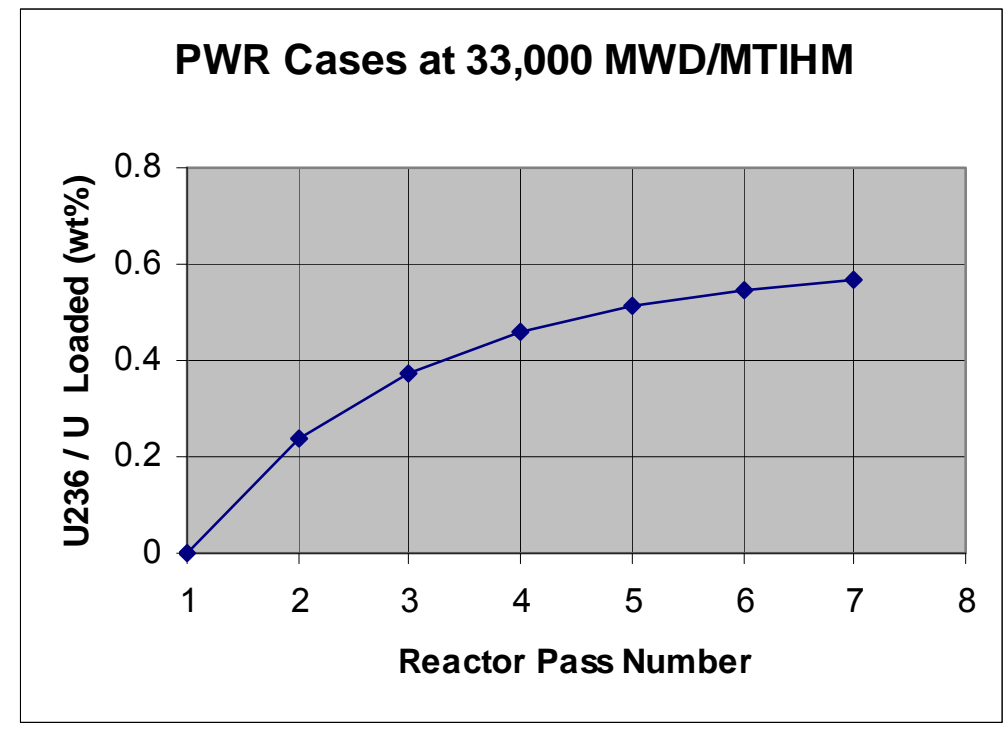

Fig. 2. Concentration of ${ }^{236} U$ in uranium of the loaded enriched product as a function of reactor passes for the $33,000 \mathrm{MWd} / \mathrm{MTIHM}$ cases. 


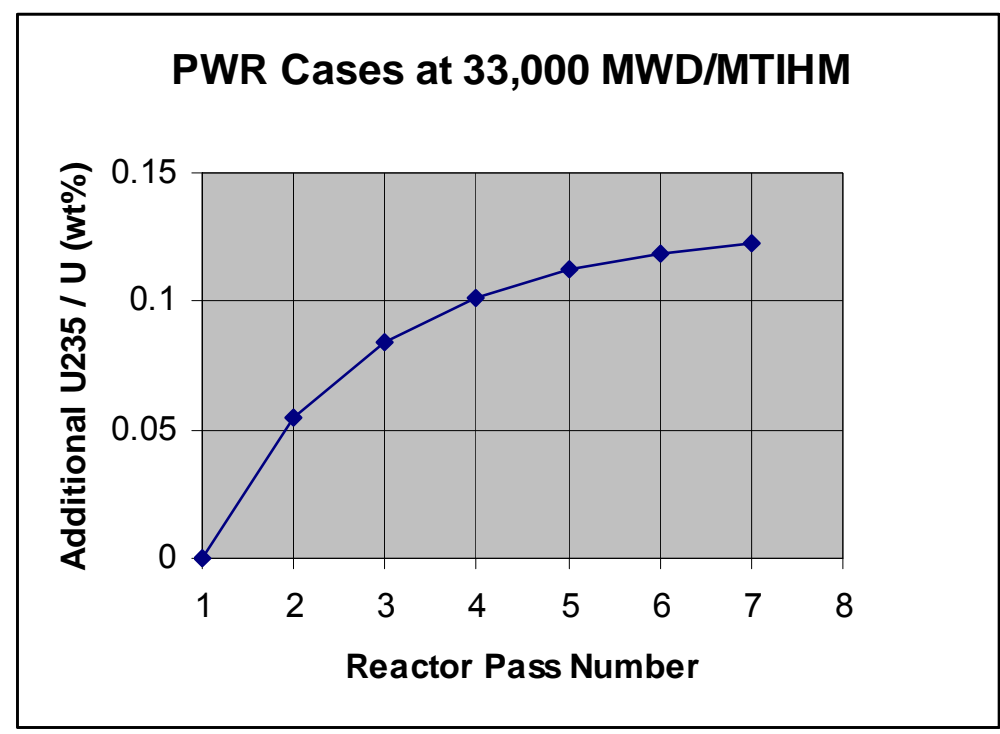

Fig. 3. Additional ${ }^{235} U$ required to compensate for the ${ }^{236} U$ in uranium of the loaded enriched product as a function of reactor passes for the 33,000 MWd/MTIHM cases.

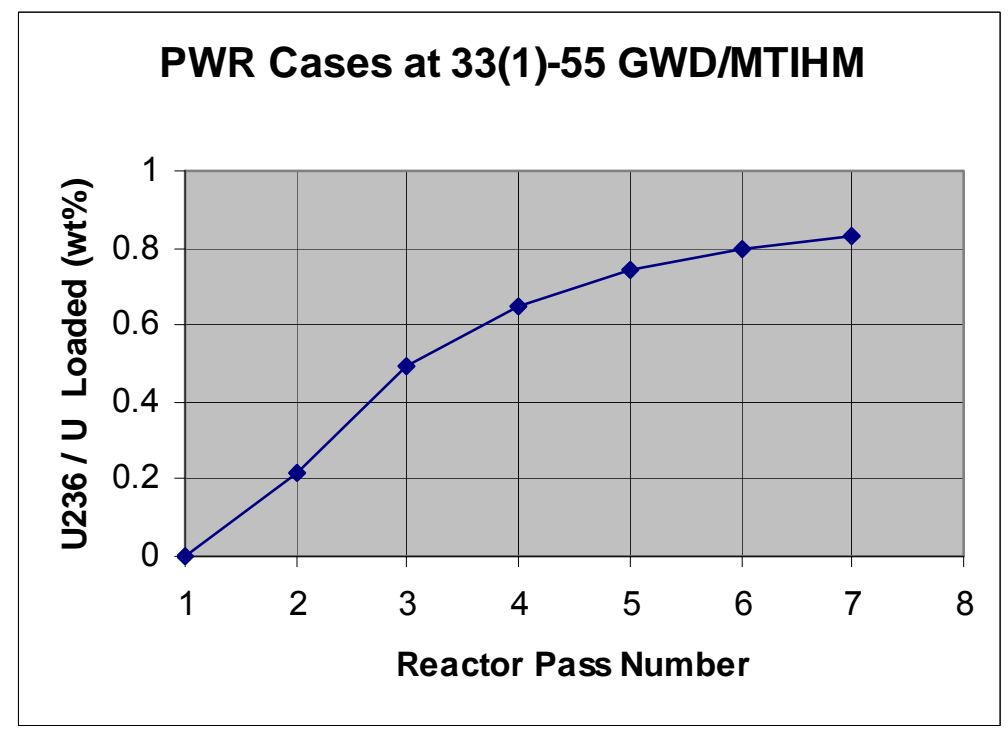

Fig. 4. Concentration of ${ }^{236} \mathrm{U}$ in uranium of the loaded enriched product as a function of reactor passes for the combined 33,000 MWd/MTIHM (reactor pass 1) and 55,000 MWd/MTIHM (reactor passes 2 to 7) cases. 


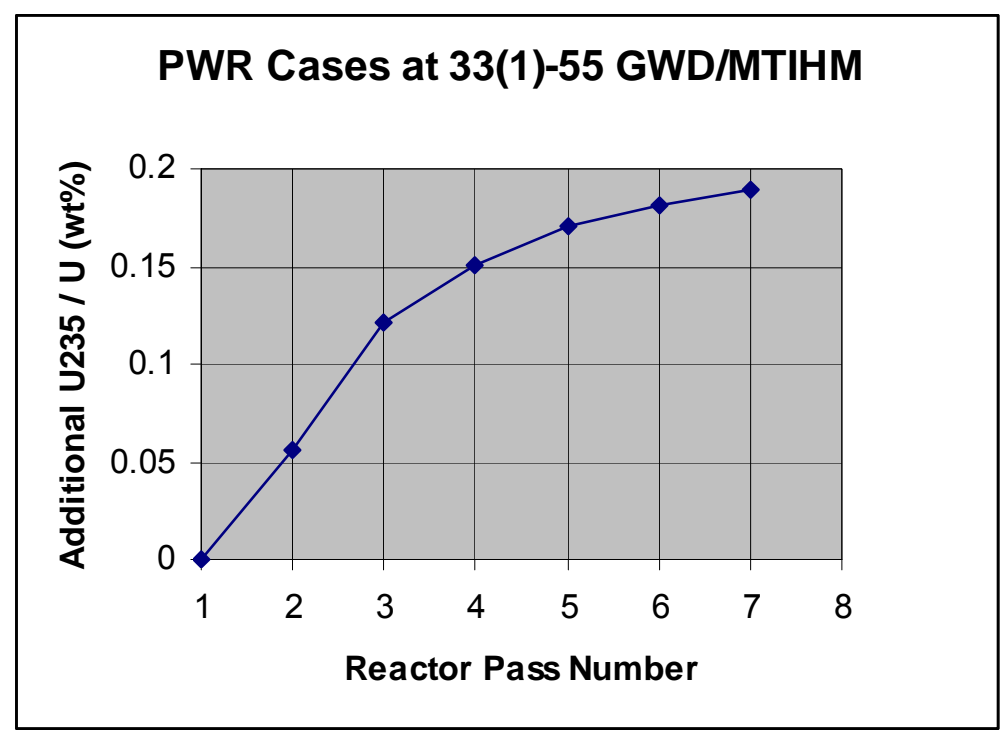

Fig. 5. Additional ${ }^{235} \mathrm{U}$ required to compensate for the ${ }^{236} \mathrm{U}$ in uranium of the loaded enriched product as a function of reactor passes for the combined 33,000 MWd/MTIHM (reactor pass 1) and 55,000 MWd/MTIHM (reactor passes 2 to 7) cases.

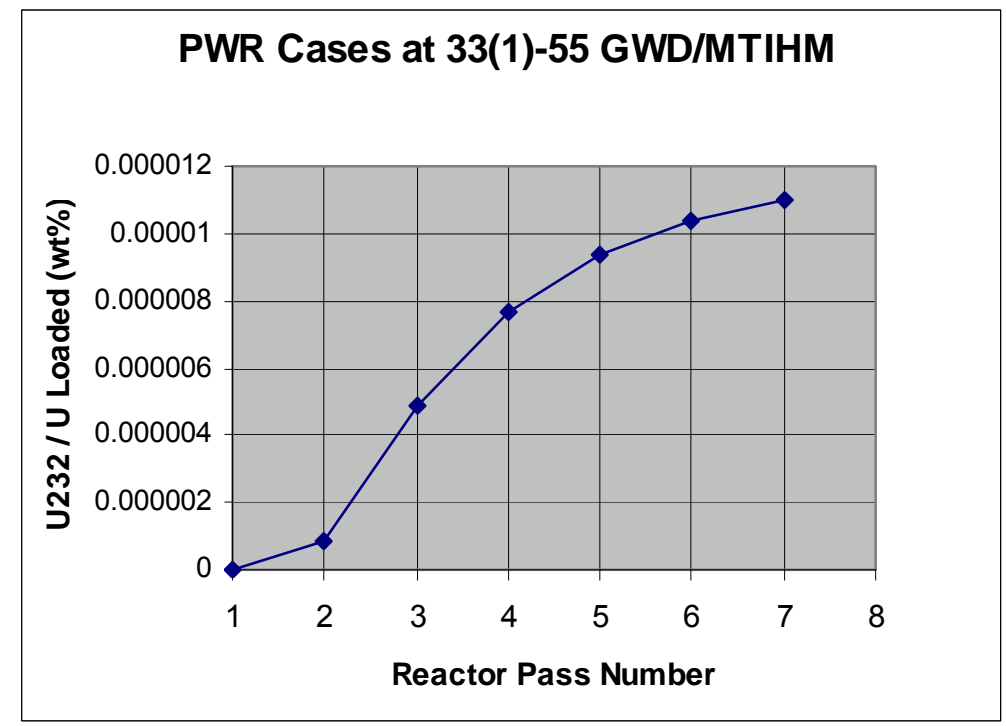

Fig. 6. Concentration of ${ }^{232} \mathrm{U}$ in uranium of the loaded enriched product as a function of reactor passes for the combined 33,000 MWd/MTIHM (reactor pass 1) and 55,000 MWd/MTIHM (reactor passes 2 to 7) cases.

The ${ }^{236} \mathrm{U}$ penalty factors were calculated for each case using the HELIOS code. Cases were run with fuel derived from all-natural uranium (at 3.0 or $4.5 \mathrm{wt} \%{ }^{235} \mathrm{U}$ ) and with fuel derived partially from RU (at slightly higher enrichment). The enrichment of the RU fuel was altered until equivalent fuel behavior was achieved, which for this purpose was defined as equivalent $\mathrm{k}_{\text {eff }}$ at fuel discharge (i.e., at target burnup of the run). The ${ }^{236} \mathrm{U}$ penalty factors derived for the various scenarios are shown in Table 7 (at the end of Sect. 2.2.1.4). The ${ }^{236} \mathrm{U}$ penalty factors vary by case. All values fall within the range reported in the literature but vary in a systematic way with scenario parameters. For 
example, the ${ }^{236} \mathrm{U}$ penalty factor appears to decrease with the addition of soluble boron to the coolant water.

Our equivalence definition relates to the EOL of the fuel in the reactor. Of course, differences throughout fuel irradiation may have other effects. Also, the enriched uranium products using RU feed could be preferentially used as fuel in the burnable poison rods, while natural uranium feed could be used for the enriched uranium product in the nonburnable poison fuel rods. For example, because of the increased neutron poisoning by initially present ${ }^{236} \mathrm{U}$, the reactor fuel depletion calculations show that the burnable poison content could be slightly reduced - to $93 \%$ of the normal value used in the case of the first reactor pass (no RU).

For any given fuel assembly, the ${ }^{236} \mathrm{U}$ compensation factors are likely to be history dependent. We have calculated the compensation factor for the different types of spent fuel considered, ranging from the earlier low-assay/low-burnup spent fuel to the higher-assay/higher-burnup spent fuel being generated at present. We have also included the presence of neutron poisons in our calculations.

In any case the calculated level of ${ }^{236} \mathrm{U}$ in PWR fuel for the highest-burnup fuel in the present U.S. spent fuel inventory (i.e., 55,000 MWd/MTU) is calculated to be $6,900 \mu \mathrm{g} / \mathrm{g}$ - a value below the ASTM RU feed limit [9] of 8,400 $\mu \mathrm{g} / \mathrm{g}$. All RU under formal consideration should be well within the ASTM enrichment feed specification.

The Tennessee Valley Authority (TVA) has agreed to utilize fuel that has a ${ }^{236} \mathrm{U}$ content above the ASTM limit (in this case, not directly from RU feed, but instead from down-blended weaponsderived HEU). The analysis done by TVA (if available) might be a good point of reference for the use of RU feed. For example, if the ${ }^{236} U$ content of the RU exceeds the feed limit of $8400 \mu \mathrm{g} / \mathrm{g}$, then the ${ }^{236} U$ concentration of the RU feed could be decreased by down-blending the RU feed with natural uranium feed. 
Table 4. Results for multiple reenrichments of uranium for a scenario of PWR reactors achieving 55,000 MWd/MTU burnups

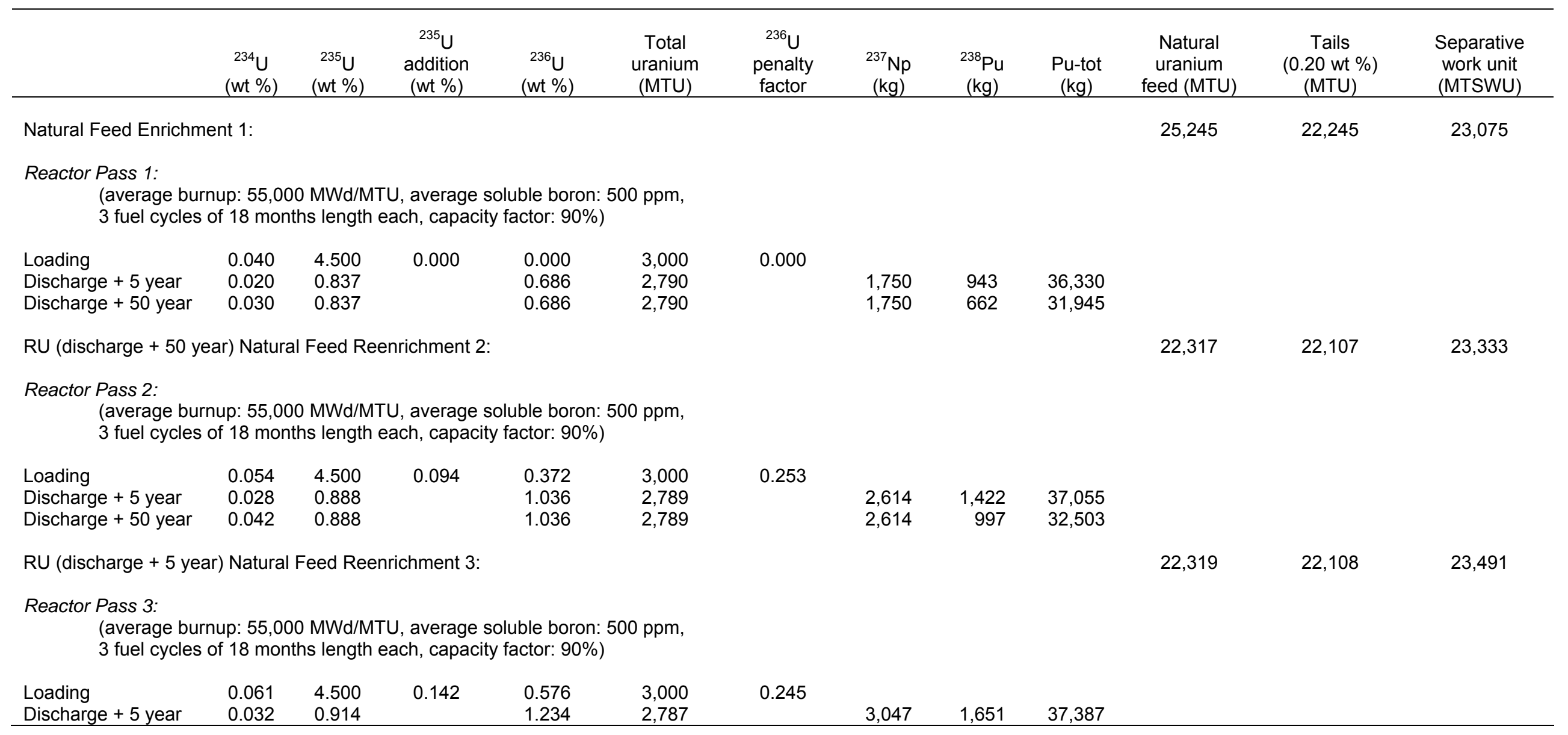


Table 5. Results for multiple reenrichments of uranium for a scenario of PWR reactors achieving 33,000 MWd/MTU burnups

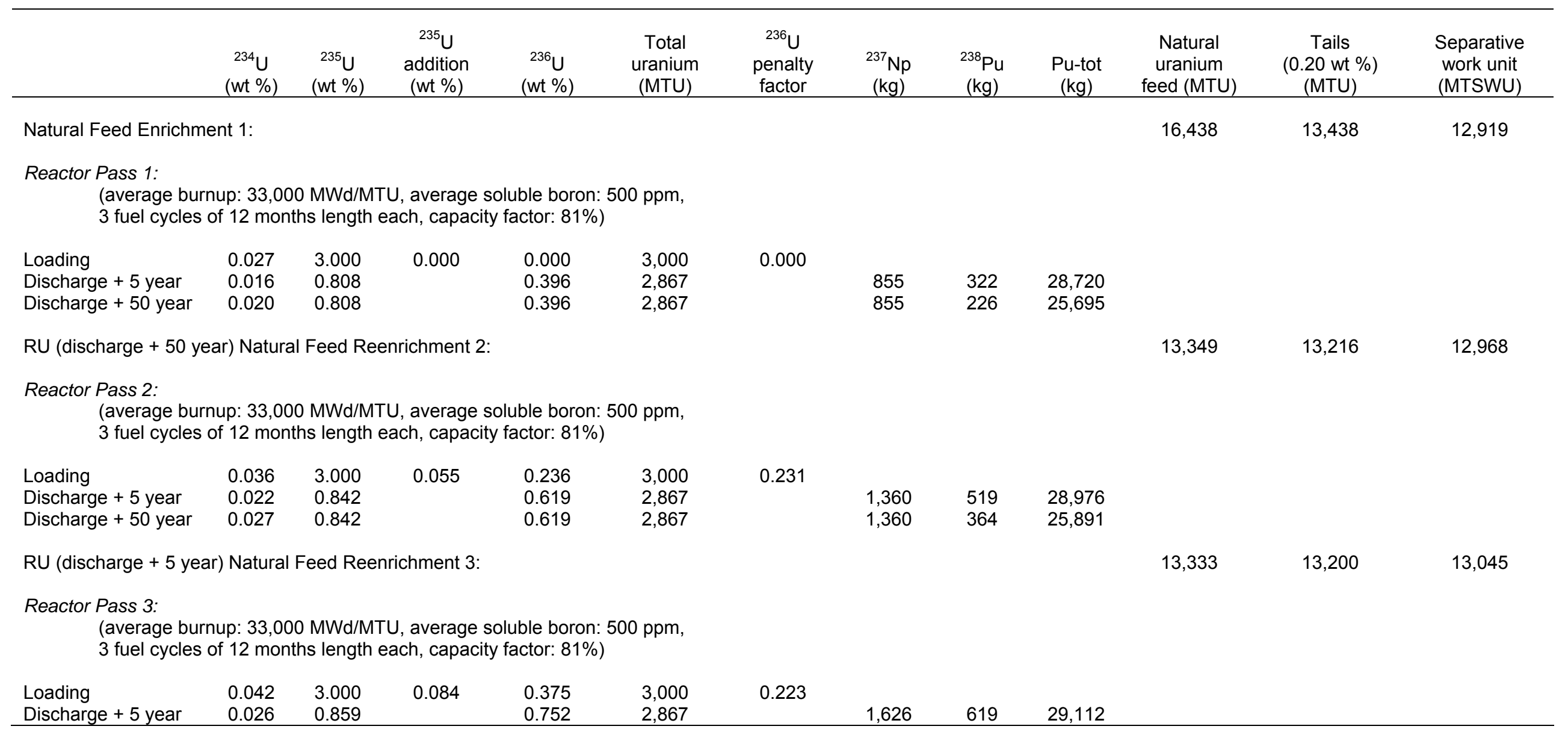


Table 6. Results for multiple reenrichments of uranium for a scenario of PWR reactors achieving 33,000 and 55, 000 MWd/MTU burnups, reactor pass 1

\begin{tabular}{|c|c|c|c|c|c|c|c|c|c|c|c|c|c|}
\hline & $\begin{array}{c}{ }^{232} \cup \\
(w t \%)\end{array}$ & $\begin{array}{c}{ }^{234} \cup \\
\text { (wt \%) }\end{array}$ & $\begin{array}{c}{ }^{235} \cup \\
\text { (wt \%) }\end{array}$ & $\begin{array}{l}{ }^{235} \mathrm{U} \\
\text { addition } \\
(\text { wt } \%)\end{array}$ & $\begin{array}{c}{ }^{236} U \\
\text { (wt \%) }\end{array}$ & $\begin{array}{l}\text { Total } \\
\text { uranium } \\
\text { (MTU) }\end{array}$ & $\begin{array}{l}{ }^{236} \mathrm{U} \\
\text { penalty } \\
\text { factor }\end{array}$ & $\begin{array}{c}{ }^{237} \mathrm{~Np} \\
(\mathrm{~kg})\end{array}$ & $\begin{array}{c}{ }^{238} \mathrm{Pu} \\
(\mathrm{kg})\end{array}$ & $\begin{array}{c}\text { Pu-tot } \\
\text { (kg) }\end{array}$ & $\begin{array}{l}\text { Natural } \\
\text { uranium } \\
\text { feed } \\
\text { (MTU) }\end{array}$ & $\begin{array}{l}\text { Tails } \\
(0.20 \text { wt } \\
\%) \\
(\mathrm{MTU})\end{array}$ & $\begin{array}{l}\text { Separative } \\
\text { work unit } \\
\text { (MTSWU) }\end{array}$ \\
\hline Natural Feed Enrichment 1: & 0.00 & 0.0055 & 0.711 & & 0.000 & & & & & & 16,438 & 13,438 & 12,919 \\
\hline \multicolumn{14}{|c|}{$\begin{array}{l}\text { Reactor Pass 1: } \\
\text { (average burnup: } 33,000 \mathrm{MWd} / \mathrm{MTU} \text {, average soluble boron: } 500 \mathrm{ppm} \text {, } \\
\text { 3 fuel cycles of } 12 \text { months length each, capacity factor: } 81 \% \text { ) }\end{array}$} \\
\hline Loading & 0.00 & 0.027 & 3.000 & 0.000 & 0.000 & 3,000 & 0.000 & & & & & & \\
\hline Discharge + 5 year & $3.70 \mathrm{E}-7$ & 0.016 & 0.808 & & 0.396 & 2,867 & & 855 & 322 & 28,720 & & & \\
\hline Discharge +50 year & $3.30 \mathrm{E}-7$ & 0.020 & 0.808 & & 0.396 & 2,867 & & 855 & 226 & 25,695 & & & \\
\hline \multicolumn{14}{|c|}{ RU (discharge + 50 year) Natural Feed Reenrichment 2: } \\
\hline Average Feed & $3.78 \mathrm{E}-8$ & 0.007 & 0.722 & & 0.045 & & & & & & 22,161 & 22,028 & 23,156 \\
\hline \multicolumn{14}{|c|}{$\begin{array}{l}\text { Reactor Pass 2: } \\
\text { (average burnup: 55,000 MWd/MTU, average soluble boron: } 500 \mathrm{ppm} \text {, } \\
\quad 3 \text { fuel cycles of } 18 \text { months length each, capacity factor: } 90 \% \text { ) }\end{array}$} \\
\hline Loading & $3.10 \mathrm{E}-7$ & 0.053 & 4.500 & 0.056 & 0.217 & 3,000 & 0.259 & & & & & & \\
\hline Discharge + 5 year & $1.92 E-6$ & 0.027 & 0.868 & & 0.889 & 2,789 & & 2,270 & 1,236 & 36,769 & & & \\
\hline Discharge +50 year & $1.62 \mathrm{E}-6$ & 0.039 & 0.868 & & 0.889 & 2,789 & & 2,270 & 867 & 32,291 & & & \\
\hline \multicolumn{14}{|c|}{ RU (discharge + 5 year) Natural Feed Reenrichment 3: } \\
\hline Average Feed & 2.13E-7 & 0.008 & 0.729 & & 0.099 & & & & & & 22,292 & 22,080 & 23,412 \\
\hline \multicolumn{14}{|c|}{$\begin{array}{l}\text { Reactor Pass 3: } \\
\text { (average burnup: 55,000 MWd/MTU, average soluble boron: } 500 \text { ppm, } \\
\text { 3 fuel cycles of } 18 \text { months length each, capacity factor: } 90 \% \text { ) }\end{array}$} \\
\hline Loading & $1.76 \mathrm{E}-6$ & 0.060 & 4.500 & 0.122 & 0.492 & 3,000 & 0.247 & & & & & & \\
\hline Discharge +5 year & $3.00 \mathrm{E}-6$ & 0.031 & 0.903 & & 1.153 & 2,787 & & 2,866 & 1,556 & 37,251 & & & \\
\hline
\end{tabular}


Table 7. U-236 penalty factors derived using the HELIOS code

\begin{tabular}{lccccc}
\hline Burnup (MWd/MTU) & 33,000 & 55,000 & $33,000 / 55,000$ & 33,000 & 55,000 \\
\hline${ }^{235} \mathrm{U}$ equiv assay & $3.0 \mathrm{wt} \%$ & $4.5 \mathrm{wt} \%$ & $3.0 \mathrm{wt} \% / 4.5 \mathrm{wt} \%$ & $3.0 \mathrm{wt} \%$ & $4.5 \mathrm{wt} \%$ \\
Soluble Boron present & Yes & Yes & Yes & No & No \\
${ }^{236} \mathrm{U}$ Penalty (pass 2) & 0.231 & 0.253 & 0.259 & 0.248 & 0.270 \\
${ }^{236} \mathrm{U}$ Penalty (pass 3) & 0.223 & 0.245 & 0.247 & 0.240 & 0.266 \\
\hline
\end{tabular}

Table 8 displays a synopsis of the results of the Doppler temperature coefficient and the moderator temperature coefficient for multiple re-enrichments of uranium for three reactor passes, each pass achieving an average fuel burnup of 55,000 MWd/MTIHM. The results show that the reenrichment of uranium makes the Doppler temperature coefficient and the moderator temperature coefficient slightly more negative, and thus enhances the reactor safety characteristics.

Table 8. Results of the Doppler Temperature Coefficient and the Moderator Temperature Coefficient for Multiple Reenrichments of Uranium for a Scenario of PWR Reactors at a Burnup of 55,000 MWd/MTIHM

\begin{tabular}{|c|c|c|c|c|}
\hline & & $\begin{array}{l}\text { Reactor Pass } 1 \\
(\mathrm{pcm} / \mathrm{K})\end{array}$ & $\begin{array}{c}\text { Reactor Pass } 2 \\
(\mathrm{pcm} / \mathrm{K})\end{array}$ & $\begin{array}{c}\text { Reactor Pass } 3 \\
(\mathrm{pcm} / \mathrm{K})\end{array}$ \\
\hline \multicolumn{5}{|c|}{ Doppler Temperature Coefficient: } \\
\hline \multirow[t]{2}{*}{ BOL,HFP,XE } & $500 \mathrm{ppm}$ & -1.43 & -1.49 & -1.52 \\
\hline & $1000 \mathrm{ppm}$ & -1.46 & -1.53 & -1.56 \\
\hline \multicolumn{5}{|c|}{ Moderator Temperature Coefficient: } \\
\hline BOL,HFP,XE & $\begin{array}{l}500 \mathrm{ppm} \\
1000 \mathrm{ppm}\end{array}$ & $\begin{array}{l}-29.4 \\
-21.0\end{array}$ & $\begin{array}{l}-30.5 \\
-22.2\end{array}$ & $\begin{array}{l}-30.8 \\
-22.7\end{array}$ \\
\hline
\end{tabular}

\subsection{PRELIMINARY ECONOMIC ANALYSIS OF THE REENRICHMENT OPTION}

Analyses of the economics of the use of RU in the uranium fuel cycle have been performed in the past [1-4]. Some studies employed very different base assumptions than those are concerned with (e.g., recycle versus direct disposal of spent fuel) [1,2] or did not consider the detail of fuel composition. Those that did consider the fuel composition detail generally used calculations derived from the lower fuel assay and lower burnups prevailing at the time of the calculations. A preliminary analysis is presented here using a methodology analogous to the one used by de la Garza [4] but extending the analysis to scenarios corresponding to a few categories of RU that could be derived from the present spent fuel inventory.

This analysis is based on several assumptions, as outlined in the following discussion. The "GNEP baseline" for this economic comparison is the scenario in which spent fuel is reprocessed, the plutonium is used in mixed-oxide (MOX) fuel, and the remainder (including fission products and $R U$ ) are disposed of. In the baseline scenario, the nominal annual reactor fuel needs for the United States are supplied by enriching natural uranium. RU-reuse scenarios are then evaluated by reference to this baseline. Thus, many costs (e.g., spent fuel reprocessing, fission product disposal, plutonium value in MOX fuel), though large and uncertain, are essentially identical for the various reuse scenarios and are not considered. The U.S. annual commercial reactor fuel needs are assumed to be a constant 3,000 MTU/year (somewhat above the current U.S. fuel demand). In the RU-reuse scenarios, this need is met by enriching a mixture of natural feed and RU feed derived from spent fuel corresponding to an original quantity of 3,000 MTU. 
Other assumptions underlying the analysis are as follows:

1. Three burnup values for PWRs are used: one typical of the earliest material (i.e., 25,000 $\mathrm{MWd} / \mathrm{MTU})$; a second, typical of more-recent values and a reasonable average for the bulk of the inventory (33,000 MWd/MTU); and the third (55,000 MWd/MTU), a higher limit that may be achieved in the near future. These represent our initial experience with three cadres of spent fuel in the present inventory and hence three types of RU to be reenriched to make fuel.

2. The reprocessing plant will process spent fuel derived from 3,000 MTU each year. (The U.S. spent fuel inventory neither increases nor decreases if nuclear power generation remains constant.)

3. The target enrichment of fuel to be produced is $4.50 \mathrm{wt} \%{ }^{235} \mathrm{U}$ equivalent in most scenarios and $3 \mathrm{wt} \%$ in a few others. Enrichment tails are assumed to be $0.20 \mathrm{wt} \%{ }^{235} \mathrm{U}$.

4. In RU-reuse scenarios, the ${ }^{235} \mathrm{U}$ enrichment is increased to compensate for the presence of ${ }^{236} \mathrm{U}$ using the method presented in Refs. [4] and [1]. The compensation factor used is 0.30 units of additional ${ }^{235} \mathrm{U}$ per unit of ${ }^{236} \mathrm{U}$ for the historical spent-fuel-inventory cases (cases for which the penalty factor was not derived). The value of 0.30 derived for the recent HELIOS calculations, is in the range used in historical calculations but is somewhat conservative (i.e., slightly higher) compared with the factors calculated by the HELIOS runs in this work.

5. Mass balance, mass flows (natural-assay feed, RU feed, product, tails), and enrichment (assay distributions among these streams) are calculated using the methodology outlined in Ref. [4]. This approach assumes a separation behavior based on mass, such as gaseous diffusion or gas centrifuge enrichment, that will also concentrate ${ }^{232} \mathrm{U},{ }^{234} \mathrm{U}$, and ${ }^{236} \mathrm{U}$ along with ${ }^{235} \mathrm{U}$. (Laser enrichment techniques should be more isotope specific and would probably coconcentrate ${ }^{234} \mathrm{U}$ and ${ }^{236} \mathrm{U}$ to a lesser degree with ${ }^{235} \mathrm{U}$ ).

6. Cost scenarios use two sets of prices. One reflects very recent spot prices: $\$ 140$ per kilogram separative work unit (kg-SWU) and $\$ 233 / \mathrm{kg} U$ for natural feed-a historic maximum). The other set of values is more typical of the recent historical average (actual values from 2004 that have been inflation adjusted to 2007 dollars): $\$ 116 / \mathrm{kg}-\mathrm{SWU}$ and $\$ 50 / \mathrm{kg}$ U natural feed) [16].

The results are presented in Tables 9-12. In each table the results are divided into four sets. The first set, which presents one reference case and three RU cases, is based on the use of RU derived from selected spent fuel in the existing U.S. inventory. In each case, RU derived from spent fuel corresponding to an original quantity of 3,000 MTU is used along with sufficient natural uranium to produce 3,000 MTU of product enriched to $4.5 \mathrm{wt} \%$-equivalent assay $\left({ }^{236} \mathrm{U}\right.$ penalty considered) with a $0.2 \mathrm{wt} \%$ enrichment tails assay. For reference, a case using all-natural uranium as feed to the enrichment plant is calculated. Three RU cases are shown - reflecting reprocessing and use of spent fuel that had experienced low $(25,000)$, medium $(33,000)$, and high $(55,000 \mathrm{MWd} / \mathrm{MTU})$ burnups.

The second set is based on the neutronics calculations previously discussed (Table 5) for medium-burnup cases. Three reactor passes are contemplated. The first one uses all-natural uranium for enrichment to $3.0 \mathrm{wt} \%$. The second and third use the RU derived from the previous pass (after a 5 year aging period), along with sufficient natural uranium to enrich into $3.0 \mathrm{wt} \%$-equivalent fuel for the next pass (with a $0.2 \mathrm{wt} \%$ tails assay). The reactor calculations use three 12 month fuel-recycle burn times, and a total burnup of 33,000 MWd/MTU.

The third set (see also Table 4) is similar to the second, except that the fuel is $4.5 \mathrm{wt} \%$-equivalent assay, has three fuel-cycle burn times of 18 months each, and a total burnup of 55,000 MWd/MTU.

The fourth set (see also Table 6) represents the most realistic case for the present situation. The initial pass uses all-natural uranium enriched to $3 \%$, with three reactor burn times of 12 months each 
and a burnup of 33,000 MWd/MTU. This represents the approximate average fuel in the existing spent fuel inventory. The spent fuel from that pass is cooled for 50 years [representing the time between reactor discharge (some which occurred decades in the past) until reprocessing (which is expected to occur a decade or so in the future]. It is then used (with natural uranium) as enrichment feed to produce $4.5 \mathrm{wt} \%$-equivalent fuel for the second pass. The second pass uses this fuel for three fuel cycles of 18 months each with a total burnup of 55,000 MWd/MTU. After a 5 year cooling period, the second-pass spent fuel is similarly used (with natural uranium) to produce feed for the third pass.

Mass balance, isotopic composition, and cost factors are presented in Tables 9-12. Table 9 shows the overall uranium mass balance for the various scenarios. RU is assumed to be fed into an enrichment plant at the location corresponding to its ${ }^{235} \mathrm{U}$ assay, while natural feed (at $0.711 \mathrm{wt} \%$ ${ }^{235} \mathrm{U}$ ) is fed at the normal feed point. The enrichment product stream assay in all cases is equivalent to either 3.0 or $4.5 \mathrm{wt} \%{ }^{235} \mathrm{U}$ after compensation for ${ }^{236} \mathrm{U}$ present in the product. The requirement for natural feed and the amount of tails generated are also shown. Finally, the total SWU requirement is listed for each scenario.

Table 9. Historical RU scenario mass balance statistics ${ }^{a}$

\begin{tabular}{|c|c|c|c|c|c|c|}
\hline Scenario & $\begin{array}{l}\mathrm{RU}^{235} \mathrm{U} \\
\text { assay }\end{array}$ & $\begin{array}{l}\text { RU mass } \\
\text { (MT) }\end{array}$ & $\begin{array}{l}\text { Nat U mass } \\
\text { (MT) }\end{array}$ & $\begin{array}{l}\text { Product mass } \\
\text { (MT) }\end{array}$ & $\begin{array}{l}\text { Tails mass } \\
\text { (MT) }\end{array}$ & $\begin{array}{c}\text { Sep work } \\
\text { needed } \\
\text { (MT-SWU) }\end{array}$ \\
\hline \multicolumn{7}{|c|}{ ORIGEN calculations [14] for selected from historical U.S. spent fuel inventory, enriched to $4.5 \%$} \\
\hline Ref: All Nat U & $\mathrm{n} / \mathrm{a}$ & 0 & 25,245 & 3,000 & 22,245 & 23,071 \\
\hline 25,000 MWd/MTU & $1.30 \%$ & 2,895 & 19,437 & 3,000 & 19,332 & 21,074 \\
\hline 33,000 MWd/MTU & $0.83 \%$ & 2,865 & 22,113 & 3,000 & 21,978 & 23,157 \\
\hline 55,000 MWd/MTU & $0.88 \%$ & 2,790 & 22,247 & 3,000 & 22,037 & 23,369 \\
\hline \multicolumn{7}{|c|}{ HELIOS calc.: $3.0 \mathrm{wt} \%$ equiv initial assay, three 12 month in-reactor 33,000 MWd/MTU burnup } \\
\hline Pass 1 All Nat U & $\mathrm{n} / \mathrm{a}$ & 0 & 16,438 & 3,000 & 13,438 & 12,919 \\
\hline Pass 2 (RU + Nat) & $0.808 \%$ & 2,867 & 13,349 & 3,000 & 13,216 & 12,968 \\
\hline Pass 3 (RU + Nat) & $0.842 \%$ & 2,867 & 13,333 & 3,000 & 13,200 & 13,045 \\
\hline \multicolumn{7}{|c|}{ HELIOS calc.: $4.5 \mathrm{wt} \%$ equiv initial assay, three 18 month in-reactor 55,000 MWd/MTU burnup } \\
\hline Pass 1 (All Nat U) & $\mathrm{n} / \mathrm{a}$ & 0 & 25,245 & 3,000 & 22,245 & 23,072 \\
\hline Pass $2(\mathrm{RU}+\mathrm{Nat})$ & $0.837 \%$ & 2,790 & 22,317 & 3,000 & 22,107 & 23,333 \\
\hline Pass 3 (RU + Nat) & $0.888 \%$ & 2,789 & 22,319 & 3,000 & 22,108 & 23,491 \\
\hline \multicolumn{7}{|c|}{ HELIOS calc.: 3 wt $\%$ from all Nat $\mathrm{U} ; 33,000$ burnup; age 50 year; $2^{\text {nd }}$ and $3^{\text {rd }}$ pass $4.5 \%$ at 55,000 burnup } \\
\hline Pass 1 (All Nat. U) & $\mathrm{n} / \mathrm{a}$ & 0 & 16,438 & 3,000 & 13,438 & 12,919 \\
\hline Pass 2 (RU + Nat) & $0.808 \%$ & 2,867 & 22,161 & 3,000 & 22,028 & 23,151 \\
\hline Pass 3 (RU + Nat) & $0.868 \%$ & 2,789 & 22,292 & 3,000 & 22,080 & 23,412 \\
\hline
\end{tabular}

${ }^{a}$ In all cases, the target equivalent ${ }^{235} \mathrm{U}$ assay is $4.50 \mathrm{wt} \%$, the enrichment product mass is 3,000 MT. Spent fuel assay and mass are derived from 3,000 MTU (from ORIGEN [14] and HELIOS [15] calculations). 
Table 10. Distribution and effects of ${ }^{235} \mathbf{U}$ and ${ }^{236} \mathbf{U}^{a}$

\begin{tabular}{|c|c|c|c|c|c|c|c|}
\hline \multirow{2}{*}{$\begin{array}{l}\text { Burnup of RU used in } \\
\text { enrichment } \\
\text { (MWd/MTIHM) }\end{array}$} & \multicolumn{2}{|c|}{${ }^{235} \mathrm{U}$ assay } & \multicolumn{4}{|c|}{${ }^{236} \mathrm{U}$ assay } & \multirow{2}{*}{$\begin{array}{c}\text { Fraction of } \\
{ }^{236} \mathrm{U} \text { mass in } \\
\text { enrichment } \\
\text { tails }\end{array}$} \\
\hline & RU Feed & Product & RU Feed & $\begin{array}{c}\text { Average } \\
\text { Feed } \\
\text { (Nat + RU) }\end{array}$ & Product & Tails & \\
\hline
\end{tabular}

ORIGEN calculations: for selected from historical U.S. SF inventory, enriched to $4.5 \mathrm{wt} \%$

\begin{tabular}{ccc|cccc|c} 
Reference - All Nat U & NA & $4.500 \%$ & 0 & 0 & 0 & 0 & NA \\
$25,000 \mathrm{MWd} / \mathrm{MTU}$ & $1.30 \%$ & $4.572 \%$ & $0.350 \%$ & $0.045 \%$ & $0.241 \%$ & $0.015 \%$ & $29 \%$ \\
$33,000 \mathrm{MWd} / \mathrm{MTU}$ & $0.83 \%$ & $4.568 \%$ & $0.410 \%$ & $0.047 \%$ & $0.227 \%$ & $0.022 \%$ & $42 \%$ \\
& & & & & & & \\
$55,000 \mathrm{MWd} / \mathrm{MTU}$ & $0.88 \%$ & $4.622 \%$ & $0.730 \%$ & $0.081 \%$ & $0.406 \%$ & $0.037 \%$ & $40 \%$
\end{tabular}

HELIOS calc.: 3.0 wt \% equiv initial assay, three 12 month in-reactor 33,000 MWd/MTU burnup

\begin{tabular}{lcc|cccc|c} 
Pass 1 (All Nat U) & $\mathrm{n} / \mathrm{a}$ & $3.000 \%$ & $0.000 \%$ & $0.000 \%$ & $0.000 \%$ & $0.000 \%$ & NA \\
Pass 2 (RU + Nat) & $0.808 \%$ & $3.055 \%$ & $0.396 \%$ & $0.070 \%$ & $0.236 \%$ & $0.032 \%$ & $38 \%$ \\
Pass 3 (RU + Nat) & $0.842 \%$ & $3.084 \%$ & $0.619 \%$ & $0.110 \%$ & $0.375 \%$ & $0.049 \%$ & $37 \%$
\end{tabular}

HELIOS calc.: 4.5 wt \% equiv initial assay, three 18 month in-reactor 55,000 MWd/MTU burnup

\begin{tabular}{ccc|cccc|c} 
Pass 1 (All Nat U) & $\mathrm{n} / \mathrm{a}$ & $4.500 \%$ & $0.000 \%$ & $0.000 \%$ & $0.000 \%$ & $0.000 \%$ & $\mathrm{NA}$ \\
Pass 2 (RU + Nat) & $0.837 \%$ & $4.594 \%$ & $0.686 \%$ & $0.076 \%$ & $0.372 \%$ & $0.036 \%$ & $42 \%$ \\
Pass 3 (RU + Nat) & $0.888 \%$ & $4.642 \%$ & $1.036 \%$ & $0.115 \%$ & $0.576 \%$ & $0.053 \%$ & $40 \%$
\end{tabular}

HELIOS calc.: 3 wt \% from all Nat U; 33k burnup; age 50 year; $2^{\text {nd }}$ and $3^{\text {rd }}$ Pass 4.5 wt $\%$ at $55 k$ burnup

\begin{tabular}{lcc|cccc|c} 
Pass 1 (All Nat U) & $\mathrm{n} / \mathrm{a}$ & $3.000 \%$ & $0.000 \%$ & $0.000 \%$ & $0.000 \%$ & $0.000 \%$ & NA \\
Pass 2 (RU + Nat) & $0.808 \%$ & $4.556 \%$ & $0.396 \%$ & $0.045 \%$ & $0.217 \%$ & $0.022 \%$ & $43 \%$ \\
Pass 3 (RU + Nat) & $0.868 \%$ & $4.622 \%$ & $0.889 \%$ & $0.099 \%$ & $0.490 \%$ & $0.046 \%$ & $41 \%$ \\
\hline
\end{tabular}

${ }^{a}$ In all cases, the target equivalent ${ }^{235} \mathrm{U}$ assay is $4.50 \%$, the enrichment product mass is 3,000 MT. Spent fuel assay and mass are derived from 3,000 MTU (from ORIGEN [14] and HELIOS [15] calculations). The ${ }^{235} \mathrm{U}$ in natural uranium is $0.711 \mathrm{wt} \%$ and in the tails is $0.2 \mathrm{wt} \%$. 
Table 11. Avoidance (positive) or excess (negative) requirements ${ }^{a}$

\begin{tabular}{|c|c|c|c|c|c|}
\hline \multirow{2}{*}{$\begin{array}{c}\text { Burnup of RU used in } \\
\text { enrichment } \\
\text { (MWd/MTU) }\end{array}$} & \multirow[t]{2}{*}{ RU assay } & \multicolumn{4}{|c|}{ Avoided (relative to fuel derived $100 \%$ from natural $\mathrm{U}$ feed) } \\
\hline & & MT-SWU & $\begin{array}{c}\text { Nat U feed } \\
(\mathrm{MT})\end{array}$ & $\begin{array}{l}\text { Tails } \\
\text { (MT) }\end{array}$ & $\begin{array}{l}\text { RU disposal } \\
\text { (MT) }\end{array}$ \\
\hline \multicolumn{6}{|c|}{ ORIGEN calculations [14] for selected from historical U.S. spent fuel inventory, enriched to $4.5 \mathrm{wt} \%$. } \\
\hline Reference - All Nat U & $\mathrm{n} / \mathrm{a}$ & 0 & 0 & 0 & 0 \\
\hline $25,000 \mathrm{MWd} / \mathrm{MTU}$ & $1.30 \%$ & 1,997 & 5,807 & 2,912 & 2,895 \\
\hline 33,000 MWd/MTU & $0.83 \%$ & -85 & 3,132 & 267 & 2,865 \\
\hline $55,000 \mathrm{MWd} / \mathrm{MTU}$ & $0.88 \%$ & -297 & 2,998 & 208 & 2,790 \\
\hline \multicolumn{6}{|c|}{ HELIOS calc.: $3.0 \mathrm{wt} \%$ equiv initial assay, three 12 month in-reactor 33,000 MWd/MTU burnup } \\
\hline Pass 1 (All Nat U) & $\mathrm{n} / \mathrm{a}$ & 0 & 0 & 0 & 0 \\
\hline Pass 2 (RU + Nat) & $0.808 \%$ & -49 & 3,089 & 222 & 2,867 \\
\hline Pass 3 (RU + Nat) & $0.842 \%$ & -126 & 3,105 & 238 & 2,867 \\
\hline \multicolumn{6}{|c|}{ HELIOS calc.: $4.5 \mathrm{wt} \%$ equiv initial assay, three 18 month in-reactor 55,000 MWd/MTU burnup } \\
\hline Pass 1 (All Nat U) & $\mathrm{n} / \mathrm{a}$ & 0 & 0 & 0 & 0 \\
\hline Pass $2(\mathrm{RU}+\mathrm{Nat})$ & $0.837 \%$ & -262 & 2,928 & 138 & 2,790 \\
\hline Pass 3 (RU + Nat) & $0.888 \%$ & -420 & 2,926 & 137 & 2,789 \\
\hline \multicolumn{6}{|c|}{ HELIOS calc.: $3 \mathrm{wt} \%$ from all Nat U; 33,000 burnup; age 50 year; $2^{\text {nd }}$ and $3^{\text {rd }}$ pass $4.5 \mathrm{wt} \%$ at 55,000 burnup } \\
\hline Pass 1 (All Nat U) & $\mathrm{n} / \mathrm{a}$ & 0 & 0 & 0 & 0 \\
\hline Pass 2 (RU + Nat) & $0.808 \%$ & -80 & 3,084 & 217 & 2,867 \\
\hline Pass 3 (RU + Nat) & $0.868 \%$ & -354 & 2,928 & 139 & 2,789 \\
\hline
\end{tabular}

${ }^{a}$ Relative to fuel derived $100 \%$ from natural uranium feed. 
Table 12. Economic interpretation for a 3,000 MT/year plant

\begin{tabular}{|c|c|c|c|c|c|c|c|}
\hline \multirow[t]{3}{*}{$\begin{array}{r}\text { Scenario } \\
\text { (if RU, burnup in } \\
\text { MWd/MTIHM) }\end{array}$} & \multirow[t]{3}{*}{ RU assay } & \multicolumn{2}{|c|}{$\begin{array}{c}\text { Scenario Cost } \\
\text { (Feed + Conversion } \\
+ \text { Enrichment }) \\
\end{array}$} & \multicolumn{2}{|c|}{$\begin{array}{c}\text { Savings using } \\
\text { RU + Nat }\end{array}$} & \multicolumn{2}{|c|}{ Unit value of RU } \\
\hline & & Avg case & High case & Avg case & High case & Avg case & High case \\
\hline & & $\$ \mathrm{M}$ & $\$ \mathrm{M}$ & $\$ \mathrm{M}$ & $\$ \mathrm{M}$ & $\$ / \mathrm{Kg} \mathrm{U}$ & $\$ / \mathrm{Kg} \mathrm{U}$ \\
\hline \multicolumn{8}{|c|}{ ORIGEN calculations [14] for selected from historical U.S. spent fuel inventory, enriched to $4.5 \mathrm{wt} \%$} \\
\hline Reference-All Nat U & $\mathrm{n} / \mathrm{a}$ & 3,939 & 9,112 & & & & \\
\hline $25,000 \mathrm{MWd} / \mathrm{MTU}$ & $1.300 \%$ & 3,437 & 7,514 & 502 & 1,598 & 173 & 552 \\
\hline 33,000 MWd/MTU & $0.830 \%$ & 3,812 & 8,429 & 127 & 683 & 44 & 239 \\
\hline $55,000 \mathrm{MWd} / \mathrm{MTU}$ & $0.880 \%$ & 3,843 & 8,489 & 96 & 623 & 34 & 223 \\
\hline \multicolumn{8}{|c|}{ HELIOS calc.: 3 wt \% equiv initial assay, three 12 month in-reactor 33,000 burnup } \\
\hline Pass 1 (All Nat U) & $\mathrm{n} / \mathrm{a}$ & 2,321 & 5,639 & & & & \\
\hline Pass $2(\mathrm{RU}+\mathrm{Nat})$ & $0.808 \%$ & 2,192 & 4,960 & 129 & 679 & 45 & 237 \\
\hline Pass $3(\mathrm{RU}+\mathrm{Nat})$ & $0.842 \%$ & 2,200 & 4,967 & 121 & 672 & 42 & 234 \\
\hline \multicolumn{8}{|c|}{ HELIOS calc.: $4.5 \mathrm{wt} \%$ equiv initial assay, three 18 month in-reactor 55,000 MWd/MTU burnup } \\
\hline Pass 1 (All Nat U) & $\mathrm{n} / \mathrm{a}$ & 3,939 & 9,112 & & & & \\
\hline Pass $2(\mathrm{RU}+\mathrm{Nat})$ & $0.837 \%$ & 3,842 & 8,500 & 97 & 612 & 35 & 219 \\
\hline Pass $3($ RU + Nat) & $0.888 \%$ & 3,860 & 8,523 & 78 & 589 & 28 & 211 \\
\hline \multicolumn{8}{|c|}{ HELIOS calc.: $3 \mathrm{wt} \%$ from All Nat U; 33,000 burnup; age 50 year; $2^{\text {nd }}$ and $3^{\text {rd }}$ pass $4.5 \mathrm{wt} \%$ at 55,000 burnup } \\
\hline Pass 1 (All Nat U) & $\mathrm{n} / \mathrm{a}$ & 2,321 & 5,639 & & & & \\
\hline Pass $2(\mathrm{RU}+\mathrm{Nat})$ & $0.808 \%$ & 3,814 & 8,439 & 125 & 673 & 44 & 235 \\
\hline Pass 3 (RU + Nat) & $0.868 \%$ & 3,853 & 8,513 & 86 & 599 & 31 & 215 \\
\hline
\end{tabular}


Table 10 shows the ${ }^{235} \mathrm{U}$ in the RU feed and in the enriched product, and the ${ }^{236} \mathrm{U}$ assay in each stream (i.e., RU feed, average feed product, and tails). The ${ }^{235} \mathrm{U}$ in natural uranium is $0.711 \mathrm{wt} \%$ and is $0.2 \mathrm{wt} \%$ in the tails in all scenarios. It should be noted that a fair fraction of the ${ }^{236} \mathrm{U}$ (about $40 \%$ in the higher-enrichment fuel scenarios) ends up in the enrichment tails. The additional ${ }^{235} \mathrm{U}$ required for these scenarios never exceeds $0.15 \mathrm{wt} \%$, which is well within the operating parameters of enrichment plants.

Table 11 shows the differences between the RU-use scenarios and the corresponding case in which the enrichment feed contains no RU. Entries are shown as "avoided" (positive) or "excess" (negative) metric ton separative work unit (MT-SWU) or MTU. The three mass categories calculated (in metric tons) natural feed that does not need to be purchased, the reduction in enrichment tails, and the RU that does not go to waste. Because of the relatively high initial enrichment of the RU in the first historical spent fuel scenario, there is a large avoidance in all categories. The second and third historical RU scenarios have moderate additional SWU requirements (to compensate for the presence of ${ }^{236} \mathrm{U}$ ) but still represent considerable savings in unpurchased natural uranium, reduction in tails. and RU disposal costs. The RU passes of the sequential calculation sets behave similarly. There is a moderate increase in the SWU requirement but a large avoidance in feed purchases and RU disposal costs, as well as a modest avoidance of enrichment tails disposal.

Table 12 contains the cost implications derived from the above results. This evaluation considers only part of the picture - that for which costs can be reasonably well-defined. This analysis explicitly considers only three items: the cost conversion of $\mathrm{RU}$ to $\mathrm{UF}_{6}$, the cost of separative work, and the cost of natural feed. Not included are the disposal costs for enrichment tails or the disposal cost of RU (were it not recycled). The following discussion elaborates on these findings.

Two price scenarios are included: one (the "high" case) uses recent prices $(\$ 12 / \mathrm{kg} \mathrm{U}$ conversion, $\$ 140 / \mathrm{kg}-\mathrm{SWU}$, and $\$ 233 / \mathrm{kg} \mathrm{U}$ for natural feed); the other (the average case) uses values closer to recent historical averages ( $\$ 7 / \mathrm{kg} U$ for conversion, $\$ 116 / \mathrm{kg}-\mathrm{SWU}$, and $\$ 50 / \mathrm{kg}$ U natural feed) [16]. By the time a reprocessing plant could be operational, more-efficient technologies should tend to lower the cost. However, the overall cost of energy will probably be higher. It is very hard to predict the future supply and demand for uranium. Present high prices will encourage the development of additional uranium sources, thereby lowering the future price. However, extensive construction of new reactors will increase the demand and tend to increase prices. For purposes of analysis, RU was considered "free." The prevailing conversion and enrichment prices in 2004 and 2007 were used, with no premium assumed for RU over natural uranium.

The economic impact of the RU-reuse scenarios (within the scope of this partial analysis) is shown in the last 4 columns of the Table 12. The "Savings" columns show the difference between the cost of each particular RU-reuse scenario and the corresponding "all-natural U" scenario. In the first scenario set (historical spent fuel), these figures range from a low of $\$ 96$ million to a high of $\sim \$ 1.6$ billion per year. In the multi-pass calculations, the annual savings range from $\sim \$ 80$ million to $\$ 680$ million. Savings are lower in later passes, but the values are always positive. To derive the "Unit value of RU" (in units of dollars per kilogram of RU, as shown in the two right-most columns) the total savings is simply divided by the quantity of RU used. In all cases the value is positive, and in only a few cases is the value lower than that for natural uranium.

As stated earlier, the costs of disposal of either enrichment tails or of RU (were the RU is not reused) were not included. At present, there are no permitted disposal sites for RU; therefore, any estimates would be highly uncertain. The RU-reuse scenarios avoid disposal of any RU and, in addition, avoid disposal of a moderate quantity of enrichment tails. Whatever the two costs may be, their effect is favorable for the RU- reuse scenarios. For example, if the life-cycle cost (including developing a disposal site) for disposal of RU were $\$ 100 / \mathrm{kg} \mathrm{U}$, the additional annual savings would be on the order of $\$ 290$ million.

Other factors not considered relate to plutonium production. First, no economic credit is taken for the energy content of plutonium since its reuse in MOX fuel is assumed to occur either in an RUdisposal or a RU-reuse scenario. Second, RU reuse will produce spent fuel (after the second reactor pass) that has about $50 \%$ more ${ }^{238} \mathrm{Pu}$ than that in spent fuel from standard LWR fuel. This additional plutonium offers some slightly better transmutation value and some additional proliferation resistance. 


\subsection{CONCLUSIONS REGARDING THE REENRICHMENT OPTION}

We have considered several scenarios involving recycle of RU into the U.S. fuel cycle. All involve use of RU at about the rate that spent fuel is expected to be generated [i.e., RU replaces a small fraction of natural feed used in uranium enrichment ( $18 \%$ for $3 \mathrm{wt} \%$-assay fuel, $\sim 12 \%$ for 4.5 wt $\%$ assay fuel)]. However, the balance of enrichment feed is natural uranium. The primary penalty for the use of RU is the presence of ${ }^{236} \mathrm{U}$, which is assumed to impose a neutronic reactivity penalty that must be overcome by additional enrichment in ${ }^{235} \mathrm{U}$. Calculations were run in this study which determined this penalty factor in most scenarios considered. The values fall within (and at the lower end) of the range of values reported in earlier studies. Penalty factors for ${ }^{236} \mathrm{U}$ are dependent on details of the reactor scenario. No attempt was made to optimize the scenarios to minimize the penalty. It is likely that some modest reduction could be achieved were this warranted.

Several categories of spent fuel are considered representative of the distribution of assays and burnup levels in the present spent fuel inventory. SWU and natural uranium feed were calculated for these fuel categories and compared with an equivalent all-natural-feed scenario.

In all scenarios considered for PWR fuel (within the limits of the scope of the analysis), reuse of RU appears to be an economically favorable proposition (relative to disposal of the RU) - both at the present peak SWU and uranium prices and for more-typical average historical prices. (The spreadsheet model presented in Appendix A operates at the single-reactor level and yields positive results similar to those obtained for the PWRs include here). BWR fuel was not explicitly analyzed, given the limited scope of this preliminary analysis.

Several factors were not explicitly included in the analysis because of the present uncertainty in their costs, such as the disposal of RU (should RU not be reused in the fuel cycle) and the cost of disposal of enrichment tails. Whatever their cost, including these factors would benefit the RU-reuse case and the savings could be quite significant. These factors were left out of the economic analysis so that the large cost uncertainties of these factors would not obscure the results.

\section{RU RECYCLE INTO CANDU REACTORS}

\subsection{CAPABILITIES OF CANDU REACTORS}

CANDU reactors that are presently being fueled using natural uranium could be advantageously operated burning full-core RU. The CANDU fleet in Canada could use approximately 2,000 to 2,800 MT of RU per year. Other possibilities include the use of plutonium-spiked uranium to extend the life of the fuel and several options for burning americium or americium/curium in CANDU reactors as a burnable poison. The main issue to be resolved with the use of RU fuel in Canadian CANDU reactor units is the extensive licensing and safety assessment processes required by the regulatory authority, CNSC.

The standard CANDU reactor concept uses natural ( $0.71 \mathrm{wt} \%$ enrichment) uranium oxide fuel and heavy water $\left(\mathrm{D}_{2} \mathrm{O}\right)$ as both moderator and coolant (in separate systems). Figure 7 is a cutaway view of a representative CANDU unit (a CANDU 6). CANDU reactors are refueled at full power. The core is subdivided into hundreds of separate pressure tubes: 380 for the CANDU 6, 480 for the CANDU $900 \mathrm{MW}$ (e) class, and 520 for the Advanced CANDU Reactor (ACR)-1000. Each pressure tube holds a string of fuel bundles (each $\sim 0.5 \mathrm{~m}$ long and weighing about $23 \mathrm{~kg}$ ) immersed in heavywater coolant (except for the ACR-1000 model, which will have light-water coolant). Surrounding the pressure tube in all CANDU designs is a low-pressure, heavy-water moderator filling the space between neighboring pressure tubes.

Because of their characteristic high neutron economy, CANDU reactors can use natural uranium. This process is accomplished through the use of low-absorption (neutron) materials, particularly heavy water and zirconium alloys; low impurity levels in other component materials; and a unique large-volume moderator (heavy water), which facilitates the thermalization of neutrons away from 
absorbing materials. Of special note, CANDU reactors employ on-power refueling for reactivity and fuel management. Unlike other reactor types, the CANDU core requires no loading of excess reactivity for long-term operation. This characteristic precludes the need for burnable neutron poisons in the core to offset excess reactivity in the early stages of the fuel cycle. CANDU reactors generally operate in a long-term equilibrium mode with continual daily incremental fuel loading.

At present there are over 40 CANDU reactors in the world. Canada has 19 operating CANDU reactors of several designs and variations. There are 11 CANDU 6 units worldwide (2 in Canada, 4 in South Korea, 2 in China, 2 in Romania, and 1 in Argentina), 2 earlier-design CANDU reactors (in India and Pakistan); and a number of operating and under-construction CANDU-like pressurizedheavy-water reactors (PHWRs) in India. Several of the CANDU reactors are presently undergoing refurbishment.

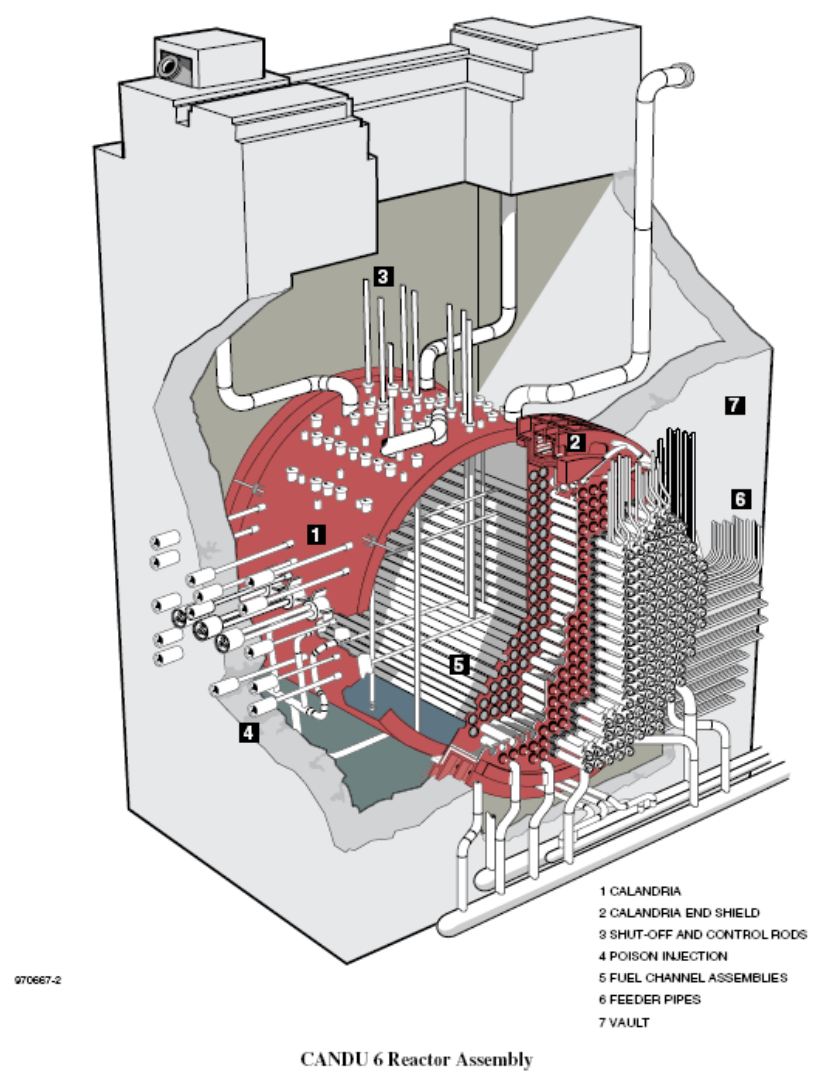

Fig. 7. Cutaway view of a CANDU 6 reactor unit.

Figure 8 shows some of the actual and potential CANDU fuel cycle options and designs [17]. Most of these use natural uranium, and some use slightly enriched uranium (SEU), between $\sim 0.9$ and $1.2 \mathrm{wt} \%$ enriched. RU is considered to be a subset of the class of SEU applications. RU does not require any reenrichment, whereas other SEU applications need some down-blending of commercial reactor fuel and natural uranium oxide.

Several types of fuel bundles are used in CANDU. Most CANDU nuclear power plants use the standard 37-element bundle (Fig. 9); however, some use the older 28-element design. The 43element CANFLEX (CANDU Flexible) fuel bundle, shown in Fig. 10 [18], is currently used in some CANDU units and is proposed for all ACR units and other CANDU nuclear power plants. 


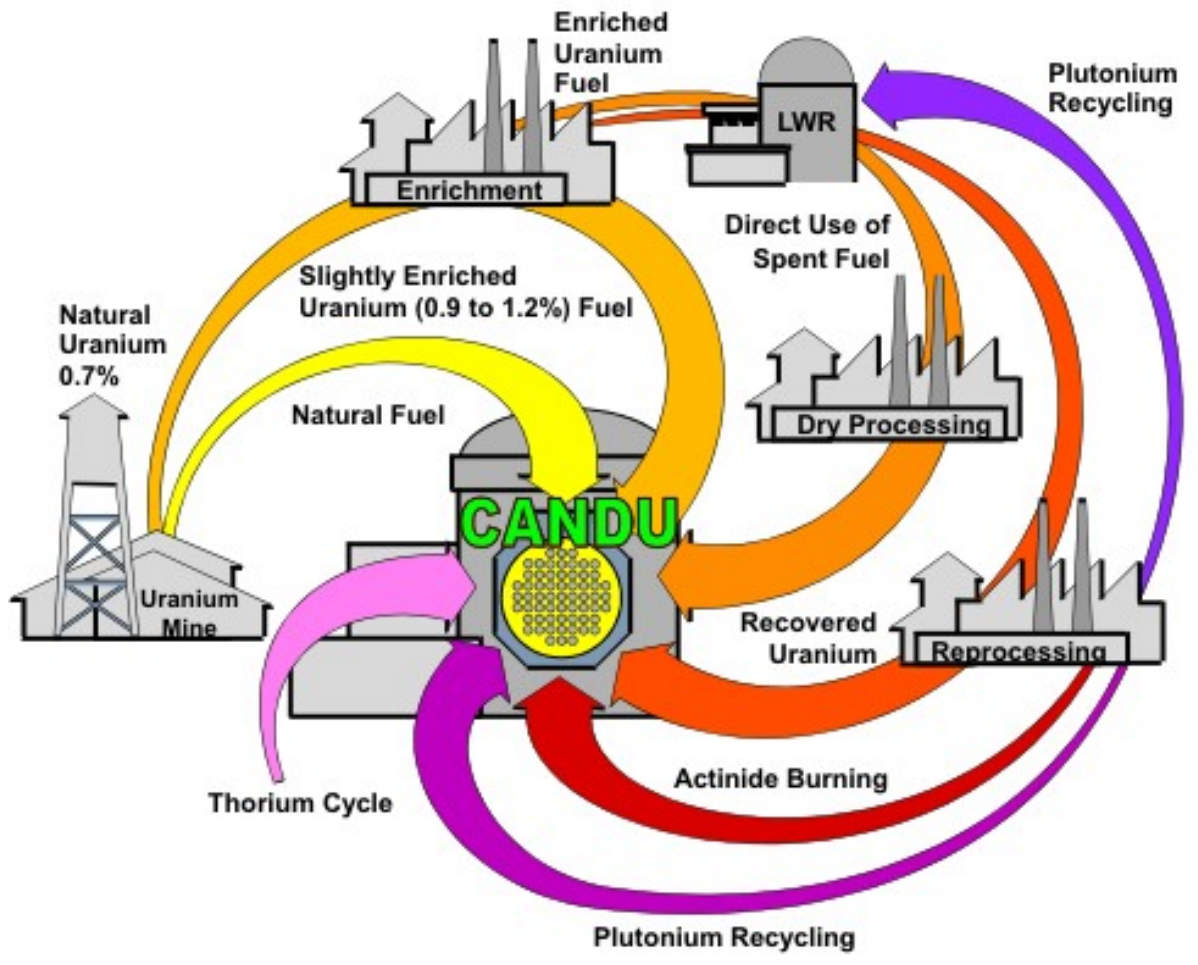

Fig. 8. Possible CANDU fuel designs/cycles.

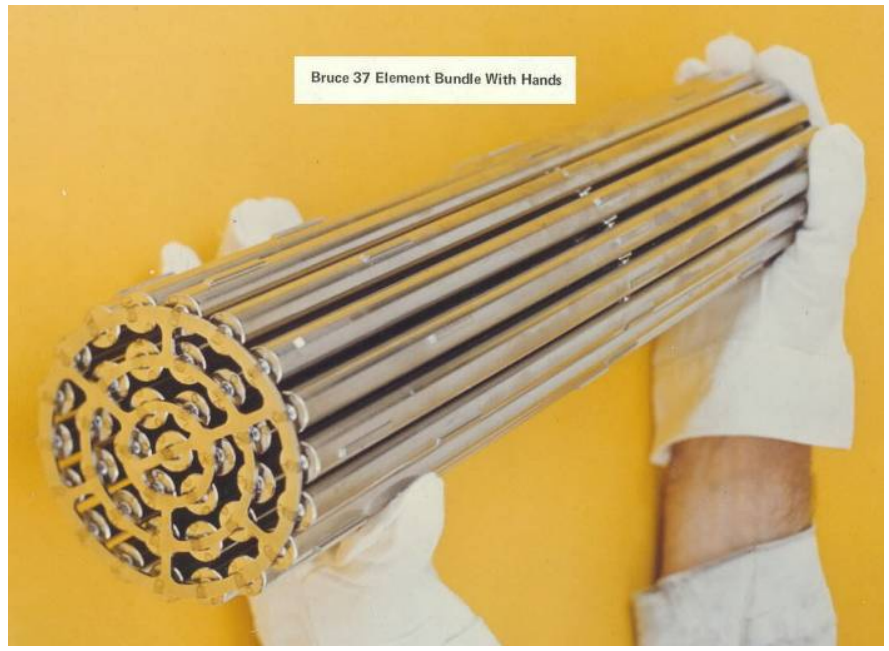

Fig. 9. Standard 37-element CANDU fuel bundle. 


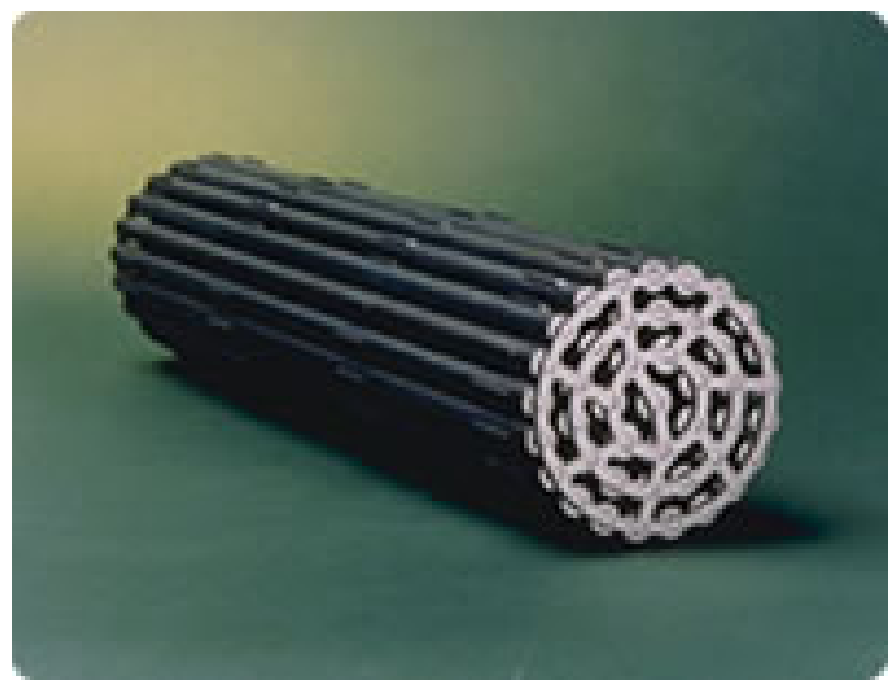

Fig. 10. 43-element CANFLEX fuel bundle.

Because the CANFLEX fuel bundle is to be used with natural uranium in many CANDU applications, it is considered a logical extension in the progression of CANDU fuel cycles for the use of RU [19, 20]. Fuel enrichments in the $0.9 \mathrm{wt} \%$ range that is typical of RU are below the threshold at which nuclear criticality considerations result in restrictions and complications in fuel fabrication and handling. When RU is used in a 480-channel CANDU 9 reactor (such as the Darlington units), the $0.9 \mathrm{wt} \%$ fuel flattens the channel power distribution sufficiently so that the reactor can generate $1100 \mathrm{MW}(\mathrm{e})$, up from the nominal rating of $935 \mathrm{MW}(\mathrm{e})$.

Korea has four CANDU 6 units (Wolsong-1 to -4) in operation. Korean researchers have explored the uses of recovered uranium under a program named "RUFIC" (eccovered Uranium Fuel

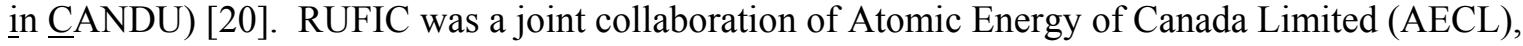
Korea Atomic Energy Research Institute (KAERI), and British Nuclear Fuels Limited (BNFL).

\subsection{EFFECT OF OTHER URANIUM ISOTOPES}

The amount of fissile material in spent nuclear fuel depends on the initial fuel enrichment, the exit burnup level of the fuel, and the cooling time for the spent fuel. For the same initial fuel enrichment, the concentration of ${ }^{235} \mathrm{U}$ decreases with increasing burnup, and the concentration of fissile plutonium increases with increasing burnup. Typically, the concentration of ${ }^{235} \mathrm{U}$ in PWR spent fuel is in the 0.8 to $1.0 \mathrm{wt} \%$ range, depending on the initial fuel enrichment, fuel neutron flux levels, and the discharge burnup level.

The concentrations of the neutron poison isotopes ${ }^{234} \mathrm{U}$ and ${ }^{236} \mathrm{U}$ were 0.02 and $0.46 \mathrm{wt} \%$, respectively, in this representative example. When a simplified CANDU case with CANFLEX fuel bundles is modeled, the residual amount of ${ }^{236} \mathrm{U}$ introduces a small reactivity load $(-0.3 \% \Delta \mathrm{k} / \mathrm{k})$ in the $\mathrm{k}_{\text {inf }}$ for an initial fresh core at beginning of life (BOL), as seen in Table 13 for a range of ${ }^{236} \mathrm{U}$ concentrations. In Table 13, small changes in reactivity load result in small changes in the average exit burnup of the CANDU fuel - from 17.4 MWd/kg heavy element (HE) to $16.7 \mathrm{MWd} / \mathrm{kg} \mathrm{HE}$.

Table 13. CANDU performance as function of ${ }^{236} \mathrm{U}$ concentration in RU

\begin{tabular}{llll}
\hline${ }^{238} \mathrm{U}(\mathrm{wt} \%)$ & 99.014 & 98.814 & 98.554 \\
${ }^{236} \mathrm{U}(\mathrm{wt} \%)$ & 0 & 0.2 & 0.46 \\
${ }^{235} \mathrm{U}(\mathrm{wt} \%)$ & 0.986 & 0.986 & 0.986 \\
${ }^{234} \mathrm{U}(\mathrm{wt} \%)$ & 0.02 & 0.02 & 0.02 \\
$\mathrm{~K}_{\text {inf }}($ fresh) & 1.25844 & 1.25615 & 1.25400 \\
$\mathrm{Exit} \mathrm{BU}(\mathrm{MWd} / \mathrm{kg} \mathrm{U})$ & 17.37 & 17.04 & 16.70 \\
\hline
\end{tabular}


In PWR analyses, the burnup penalty caused by the concentration of ${ }^{236} \mathrm{U}$ in RU needs to be offset by additional ${ }^{235} \mathrm{U}$ (i.e., $\sim 25 \%$ of the weight percent of the ${ }^{236} \mathrm{U}$ ). However, the effect in the CANDU reactor is much smaller. Tables 14 and 15 tabulate the effect of adding progressively larger amounts of additional ${ }^{235} \mathrm{U}$ for two concentrations of ${ }^{236} \mathrm{U}$. The resulting changes in the initial $\mathrm{k}_{\text {inf }}$ and the exit burnup of the fuel assemblies are shown.

Table 14. CANDU performance as function of ${ }^{235} \mathrm{U}$ concentration in RU for $0.20 \mathrm{wt} \%{ }^{236} \mathrm{U}$

\begin{tabular}{llllllll}
${ }^{238} \mathrm{U}(\mathrm{wt} \%)$ & 98.814 & 98.808 & 98.804 & 98.794 & 98.774 & 98.754 & 98.734 \\
${ }^{236} \mathrm{U}(\mathrm{wt} \%)$ & 0.2 & 0.2 & 0.2 & 0.2 & 0.2 & 0.2 & 0.2 \\
${ }^{235} \mathrm{U}($ wt \%) & 0.986 & 0.992 & 0.996 & 1.006 & 1.026 & 1.046 & 1.066 \\
${ }^{234} \mathrm{U}(\mathrm{wt} \%)$ & 0.02 & 0.02 & 0.02 & 0.02 & 0.02 & 0.02 & 0.02 \\
$\mathrm{k}_{\text {inf }}$ (fresh) & 1.25615 & 1.25850 & 1.26006 & 1.26392 & 1.27149 & 1.27885 & 1.28603 \\
Exit burnup & 17.04 & 17.21 & 17.31 & 17.58 & 18.11 & 18.63 & 19.14 \\
(MWd/kg U) & & & & & & & \\
\hline
\end{tabular}

Table 15. CANDU performance as function of ${ }^{235} U$ concentration in $R U$ for $0.46 \mathbf{w t} \%{ }^{236} U$

\begin{tabular}{llllllll}
\hline${ }^{238} \mathrm{U}($ wt \%) & 98.554 & 98.540 & 98.531 & 98.508 & 98.462 & 98.416 & 98.370 \\
${ }^{236} \mathrm{U}($ wt \%) & 0.46 & 0.46 & 0.46 & 0.46 & 0.46 & 0.46 & 0.46 \\
${ }^{235} \mathrm{U}($ wt \%) & 0.986 & 1.000 & 1.009 & 1.032 & 1.078 & 1.124 & 1.170 \\
${ }^{234} \mathrm{U}($ wt \%) & 0.02 & 0.02 & 0.02 & 0.02 & 0.02 & 0.02 & 0.02 \\
$\mathrm{~K}_{\text {inf }}$ (fresh) & 1.25400 & 1.25946 & 1.26292 & 1.27156 & 1.28809 & 1.30367 & 1.31839 \\
Exit burnup & 16.70 & 17.07 & 17.31 & 17.92 & 19.10 & 20.25 & 21.36 \\
(MWd/kg U) & & & & & & & \\
\hline
\end{tabular}

The calculated results for $\mathrm{k}_{\text {inf }}$ and exit burnups listed in Tables 14 and 15 are displayed in Figs. 11 and 12 , respectively. These findings indicate that in order to achieve the same exit burnup for the CANDU (RU) fuel assemblies, additional ${ }^{235} \mathrm{U}$ amounting to approximately $5 \%$ of the ${ }^{236} \mathrm{U}$ concentration will have to be added. This amount is about 5 times lower than that required to compensate for the ${ }^{236} \mathrm{U}$ effect in PWR reactors. Furthermore, KAERI researchers [20] report that the reactivity effects due to $\pm 50 \%$ variations in the concentration levels of ${ }^{234} \mathrm{U}$ and ${ }^{236} \mathrm{U}$ are negligible to the operation of the CANDU 6 reactors in Korea (Wolsong-1 to -4 ).

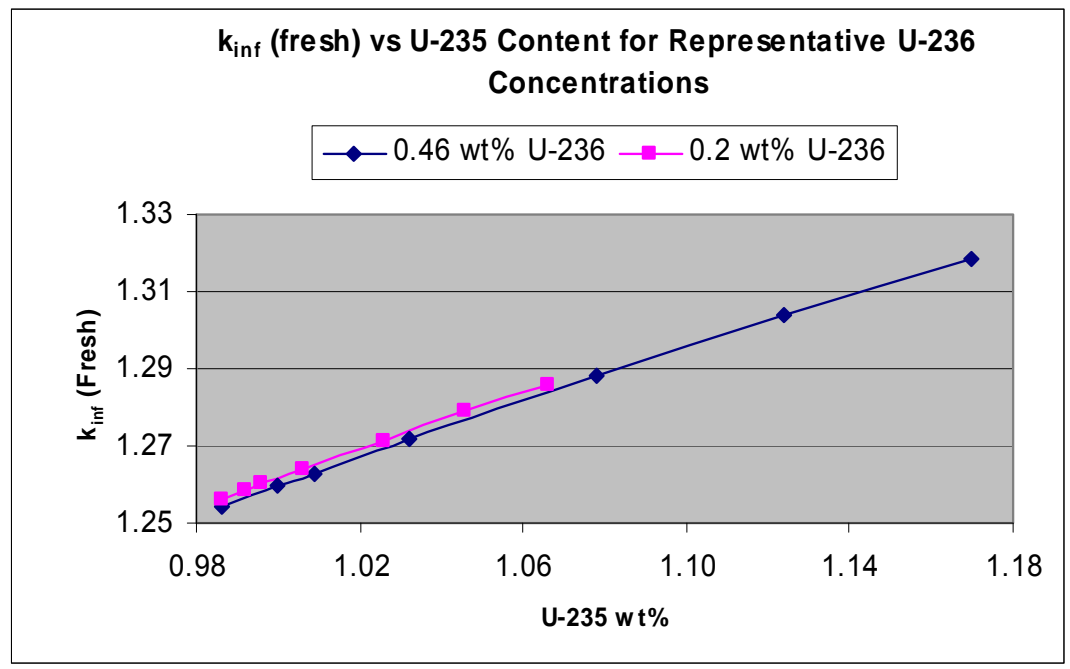

Fig. 11. $k_{\text {inf }}$ (fresh) versus ${ }^{235} U$ in $R U$ in CANDU. 


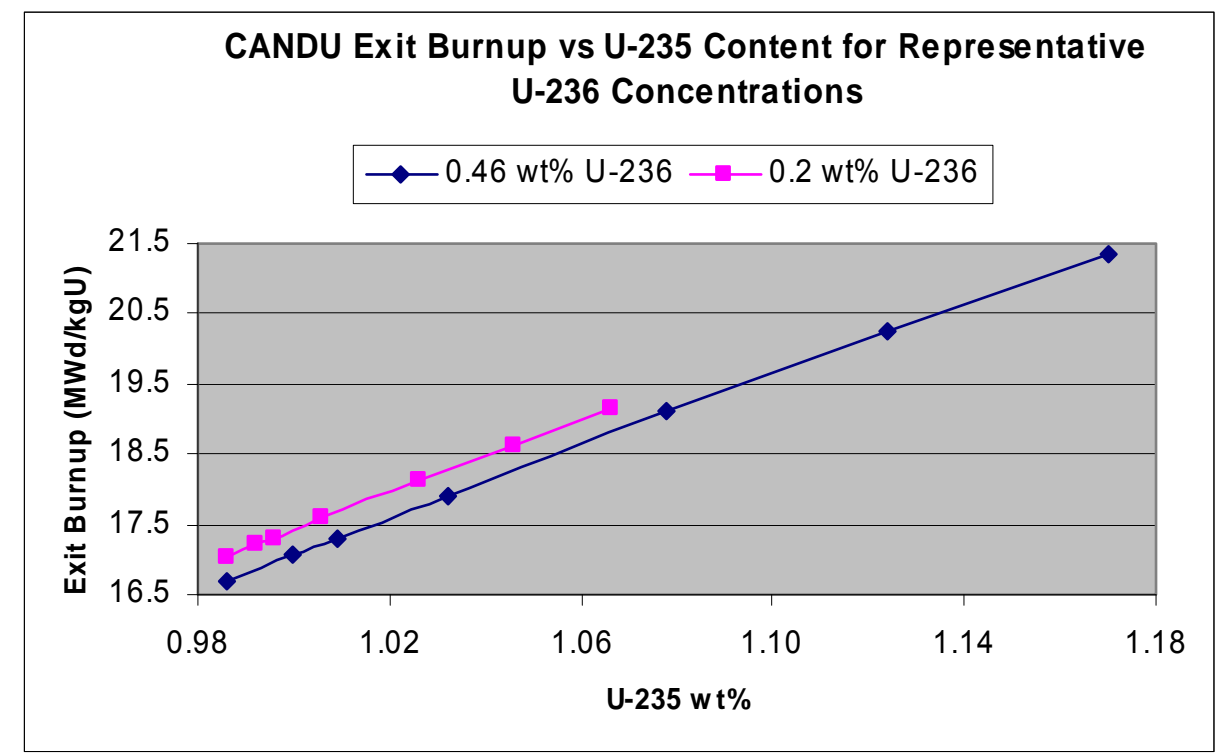

Fig. 12. Exit burnup versus ${ }^{235} U$ content in RU in CANDU CANFLEX.

\subsection{ECONOMICS OF USE OF RU IN CANDU REACTORS}

Because no enrichment of LWR RU is required for use in CANDUs, the economics of this application are even more attractive than those for RU recycle in LWRs. In addition, there is no need to deal with enrichment plant tails. The major savings is the avoided cost of purchasing uranium ore. Pursuit of this option by Canada would allow more Canadian ore to be sold on the international market, because domestic use could be cut significantly. Table 16 shows that for high ore prices (assumed cost of $\$ 233 / \mathrm{kg} \mathrm{U}$ ), the unit cost associated with RU use is half that for CANDU fuel assemblies derived from virgin (mined) $\mathrm{U}_{3} \mathrm{O}_{8}$. This is true even if fabrication of $\mathrm{RU}$ incurs a higher unit cost because of the radiation hazard associated with ${ }^{232} \mathrm{U}$ daughters. A useful next step in the pursuit of this option would be discussions with Canadian fuel fabricators and AECL. 


\section{Table 16. Comparison of CANDU unit fuel costs}

from reprocessed and virgin uranium

\begin{tabular}{|lc|}
\hline \multicolumn{2}{|c|}{ Economics of the Use of LWR Reprocessed U in CANDU Reactors } \\
\hline NATURAL U CANDU FUEL FROM URANIUM ORE: & $89.6 \$ / l b$ U3O8 \\
Uranium ore price (English) & $233 \$ / \mathrm{kgU}$ \\
Uranium mine \& mill price (Metric) (as if U3O8 produced) & $10 \$ / \mathrm{kgU}$ \\
Canadian conv of U-mill solutions to pure reactor-grade UO2 & $100 \$ / \mathrm{kgU}$ \\
CANDU fuel fabrication price (from UO2 powder) & $343 \$ / \mathrm{kgU}$ \\
Total cost & \\
& \\
CANDU FUEL FROM LWR REPROCESSED U* & $40 \$ / \mathrm{kgU}$ \\
Dissolution of RU3O8, cleanup of sol'n, and conversion to \\
UO2 of right powder morphology \\
CANDU fuel fab price (adj for higher handling risk) \\
$\begin{array}{l}\text { Total cost } \\
\text { * No enrichment step assumed. } \sim 0.7 \%-0.9 \% \text { U-235 in RU; } \\
\text { some U-236 present }\end{array}$ \\
\hline
\end{tabular}

\subsection{CONCLUSIONS REGARDING THE CANDU OPTION}

CANDU reactors can utilize RU fuel directly, without the expense and complexity of reenrichment. The use of RU fuel in Canadian CANDU reactor units will require extensive licensing and safety assessment processes with the regulatory authority, CNSC. However, a mutually agreeable consequence of the higher-than-natural enrichment of RU is that it may allow use of some of the excess reactivity from the RU fuel to offset fuel design options incorporated to reduce coolant void ratio (CVR). These measures usually involve the use of rare earth oxides (such as dysprosia) in the central fuel elements of the CANDU fuel bundles, which would impose a reactivity penalty. Also, if the RU fuel contains more fission products than planned, depending on the processing procedure, the excess reactivity resulting from the RU enrichment can offset their neutron poisoning effect and still result in a higher discharge burnup value for the fuel.

RU fuel in CANDU applications is expected to increase average exit fuel burnup from nominally $7.5 \mathrm{MWd} / \mathrm{kg} \mathrm{HE}$ to approximately $10 \mathrm{MWd} / \mathrm{kg} \mathrm{HE}$. A typical CANDU 6 reactor with natural uranium oxide fuel will use approximately 5,200 fuel bundles per year, or about $100 \mathrm{MT}$ of natural uranium per year. Depending on the specific CANDU nuclear power plants and their fuel cycles, the CANDU fleet in Canada could use approximately 2,000 to 2,800 MT of RU per year.

Since the ${ }^{235} \mathrm{U}$ content in RU exceeds that of natural uranium, CANDU offers the advantageous option of uranium recycling without re-enrichment. The RU fuel cycle in CANDU would extract at least $25 \%$ more energy from the mined uranium going into the LWR fuel cycle. Compared with reenrichment of the RU for use in LWRs, about twice as much energy can be extracted without reenrichment when the RU is used in a CANDU nuclear power plant. Another important 
consideration is that the uranium feed for CANDU fuel may not require the same stringent levels of purification traditionally required for reenrichment feed. 



\section{REFERENCES}

1. The Economics of the Nuclear Fuel Cycle, Nuclear Energy Agency, Organization for Economic Cooperation and Development (NEA/OECD), 1994.

2. M. Bunn et al., "Economics of Reprocessing versus Direct Disposal of Spent Nuclear Fuel," Nuclear Technology 150, 209 (2005).

3. IAEA, Management of Reprocessed Uranium: Current Status and Future Prospects, IAEATECDOC-1529, February 2007.

4. A. de la Garza, "Uranium-236 in Light Water Reactor Spent Fuel Recycled to an Enriching Plant," Nuclear Technology 32, 176 (1977).

5. G. Mani, Converdyn, Senior Vice President for International Marketing and Sales, private communication with L. D. Trowbridge, Oak Ridge National Laboratory, April 2, 2007.

6. D. A. Waters, USEC/Chief Scientist, American Centrifuge Program, private communication with L. D. Trowbridge, Oak Ridge National Laboratory, May 3, 2007.

7. J. D. McGaugh, (USEC) private communication with L. D. Trowbridge, Oak Ridge National Laboratory, January 1, 2003.

8. "Standard Specification for Nuclear-Grade Uranyl Nitrate Solution," ASTM Spec. C-788-98, 1998.

9. "Standard Specification for Uranium Hexafluoride for Enrichment," ASTM Spec. C-787-96, September 1996.

10. "Standard Specification for Uranium Hexafluoride Enriched to Less Than 5\% 235U," ASTM Spec. C-996-96, September 1996.

11. "Standard Specification for Nuclear-Grade, Sinterable Uranium Dioxide Powder," ASTM Spec. C-753-99, 1999.

12. "Standard Specification for Sintered Uranium Dioxide Pellets," ASTM Spec. C-776-00, 2000.

13. "Standard Specification for Blended Uranium Oxides with a ${ }^{235} U$ Content of Less Than $5 \%$ for Direct Hydrogen Reduction to Nuclear Grade Uranium Dioxide," ASTM Spec. C-1348$01,2001$.

14. C. W. Alexander, Oak Ridge National Laboratory, private communication (regarding results of ORIGEN runs) with G. D. Del Cul, Oak Ridge National Laboratory, December 2, 2002.

15. HELIOS Version 1.8, Studsvik-Scandpower, 2003.

16. The Ux Consulting Company, LLC, web site, Current prices (SWU; UF 6 ), February 2007, http://www.uxc.com/index.html

17. W. W. R. Inch, P. Thompson, and H. C. Suk, "CANFLEX: From Development Concept to a Proven Fuel," Proceedings of the KAIF/KNS Annual Conference, Seoul, Korea, April 15-16, 1998. 
18. M. R. Wash, W.W. R. Inch, R. J. Page, and G. Marsh, "Recycled Uranium-An Advanced Fuel for CANDU Reactors," IAEA-TECDOC-1122, Proceedings of the IAEA Technical Committee Meeting on Fuel Cycle Options for Light-Water Reactors and Heavy-Water Reactors, Victoria, Canada, April 28-May 1, 1998.

19. H. C. Suk, K-S Sim, and B. G. Kim, "CANFLEX-RU Fuel Development Program as One Option of Advanced Fuel Cycles in Korea," Proceedings of IAEA Technical Committee Meeting on Fuel Cycle Options for Light-Water Reactors and Heavy-Water Reactors, Victoria, Canada, April 28-May 1, 1998.

20. S. K. Kim and H. C. Suk, Tolerances of Isotopic Variations of RUFIC Fuel in the CANDU 6 Reactor, KAERI/TR-2205/2002, June 2002. 


\section{APPENDIX A: INDEPENDENT VERIFICATION OF RU ECONOMICS USING GEN IV/GNEP SPREADSHEET MODELING TOOLS}

\section{Introduction and Assumptions}

The economic analysis described up to this point considers the material flows supported by a fleet of LWRs with a total BOL uranium requirement of 3,000 MT/year, (i.e., the amount of heavy metal that would be reprocessed annually by a large aqueous recycle facility). For a fleet of PWRs operating at a burnup of 55,000 MWd/MTIHM, the annual savings in front-end fuel-cycle costs was projected to be $\$ 623 \mathrm{M}$ - assuming high costs for ore $(\$ 230 / \mathrm{kg} \mathrm{U})$, conversion $(\$ 12 / \mathrm{kg} \mathrm{U})$, and enrichment (\$140/SWU). ORNL has developed a spreadsheet model that operates at the singlereactor level to calculate the average levelized unit electricity cost (LUEC), usually expressed in mills per kilowatt-hour or dollars per megawatt-hour. The model has the capability to break this cost down into four major components: capital recovery, nonfuel operating and maintenance (O\&M), fuel cycle, and decontamination and decommissioning (D\&D) costs. This model is called G4-ECONS

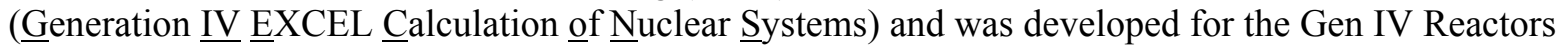
Program to perform "level playing field" economic comparison of reactor options (Ref A-1). It can also be used to compare Gen III+ options, such as advanced light-water reactors (ALWRs). It can presently handle three types of "equilibrium" fuel cycles: (1) open (no RU or plutonium recycle, with repository emplacement of spent fuel); (2) partial recycle (recycle of plutonium as MOX and the option to recycle or dispose of RU); and (3) totally closed (fast reactor cycles with high conversion ratios.). The G4-ECONS results with a single 55,000 MWd/MTIHM PWR were compared with those multi-LWR fleet numbers calculated previously in this report. The following assumptions are assumed are made:

1. For a burnup of 55,000 MWd/MTIHM, a single PWR would require on average $22.7 \mathrm{MT}$ of $4.5 \%{ }^{235} \mathrm{U}$-enriched uranium (or its equivalent in MOX or RU-LEU) annually. This means that a fleet of 132 such PWRs would be supported by the 3,000 MTIHM/year reprocessing plant, which is the basis for most of the calculations in this report. The RU-associated frontend fuel-cycle cost savings of $\$ 623 \mathrm{M} /$ year mentioned above distributed over 132 PWRs equates to $\$ 4.7 \mathrm{M} /$ reactor-year for the single-reactor calculation. The same annual figure of merit will now be calculated with G4-ECONS.

2. For all cases the reactor is assumed to have a net capacity of $1,300 \mathrm{MW}(\mathrm{e})$, to have a capacity factor of $90 \%$, and to produce $1.02 \times 10^{10}$ kilowatt-hours of electricity per year. Figs. A-1 to A-3 (at the end of this appendix) show the three cases for this reactor: the open cycle with no MOX or RU recycle, a "partially closed" case with both MOX and RU recycle, and a "partially closed" case with MOX recycle and geologic disposal of the RU.

3. For all cases the "high" values are used for ore, conversion, and enrichment costs. (The values are given in the initial paragraph of this appendix.)

4. For all cases the total fuel cycle cost in both millions of dollars per year and mills per kilowatt-hour is calculated. This includes both front end [ore, $\mathrm{U}_{3} \mathrm{O}_{8}$-to- $\mathrm{UF}_{6}$ conversion, enrichment of virgin (nonreprocessed) uranium, and fabrication of virgin $\mathrm{LEUO}_{2}$ fuel] and back end costs (spent fuel storage and repository disposal for the open cycle; spent fuel storage, aqueous spent fuel reprocessing, waste disposal, MOX fabrication, RU conversion, RU reenrichment, REPR-LEU fabrication, and the option of geologically disposing of the RU). Reactor-related costs are not included, since they would be expressed in other nonfuel components of the LUEC.

5. For the partial-recycle cases, the annual costs of preparing MOX and REPR-LEU fuel assemblies are calculated, assuming that these assemblies can replace normal $\mathrm{LEUO}_{2}$ fuel assemblies on a one-for-one energy-equivalent basis. If $53 \mathrm{LEUO}_{2}$ assemblies per year are charged to the reactor, partial recycle can return 6.6 REPR-LEU assemblies and 6.0 MOX assemblies. This makes use of $24 \%$ of the fissile products in a $\mathrm{LEUO}_{2}$ spent fuel assembly. 
Note that assembly charging rates are annualized and that in reality, new reload assemblies are introduced only every 18 months.

6. In order to produce the same amount of energy as a $4.5 \%{ }^{235} \mathrm{U}$ "virgin" LEU fuel assembly, the MOX assembly must have a plutonium enrichment of $8 \%$ in depleted uranium dioxide $\left(\mathrm{DUO}_{2}\right)$ and the REPR-LEU assembly a uranium enrichment of $5.5 \%$ (see \#7) to compensate for the parasitic effects of ${ }^{236} \mathrm{U}$. The unit costs for handling the RU streams have been elevated somewhat above those for virgin uranium to account for the more stringent environment, safety, and health $(\mathrm{ES} \& \mathrm{H})$ and handling requirements associated with the somewhat higher radiation fields $(\$ 15 / \mathrm{kg} \mathrm{U}$ for conversion of uranium nitrate hexahydrate (UNH) to $\mathrm{UF}_{6}, \$ 150 / \mathrm{SWU}$ for reenrichment, and $\$ 300 / \mathrm{kg} \mathrm{LEU}$ for fabrication).

7. For the RU-recycle case, it is assumed that the only uranium entering the enrichment plant is RU. G4-ECONS does not presently have the capability to allow the introduction of natural uranium as a side stream into the RU-fed enrichment plant. This means the ${ }^{236} \mathrm{U}$ assay of the REPR-LEU fuel may be undesirably high. Use of a significantly higher ${ }^{235} \mathrm{U}$ assay compensates for this fact. (The " 0.3 rule of thumb" was used.)

8. The cases with recycle include the costs of PUREX (plutonium-uranium extraction) reprocessing and the handling of the vitrified, intermediate-level waste (ILW), and low-level waste (LLW). The head-end and separations part of reprocessing is assumed to cost $\$ 800 / \mathrm{kg}$ heavy metal (HM). The vitrification, packaging, transportation, and repository emplacement of the glass logs are assumed to cost $\$ 200 / \mathrm{kg} \mathrm{HM}$. Fabrication of MOX fuel is assumed to cost $\$ 3200 / \mathrm{kg} \mathrm{HM}\left(\mathrm{DUO}_{2}\right.$ diluent $\left.+\mathrm{PuO}_{2}\right)$.

9. If the spent LWR fuel is recycled and only MOX fuel is recovered, the RU must undergo some form of permanent disposition. It is assumed that $\mathrm{UNH}-$ to- $\mathrm{U}_{3} \mathrm{O}_{8}$ conversion, packaging, transportation, and geologic disposition of this "waste" stream can be accomplished for $\$ 120 / \mathrm{kg} \mathrm{U}$.

\section{Open Cycle Case}

For purposes of comparison, the open cycle as currently operated by PWRs is shown schematically in Figure A-1. Each box represents a fuel-cycle step and, with the exception of the reactor, shows an assumed unit cost. Multi-year cask storage of the spent fuel at the reactor site is assumed to constitute $\$ 180 / \mathrm{kg} \mathrm{HM}$ of the back-end cost. The repository costs are assumed to be covered by the $1 \mathrm{mill} / \mathrm{kWh}$ waste fee, although the costs could likely increase significantly in the future. In terms of dollars per kilogram of HM, the waste fee (repository) translates to $\$ 451 / \mathrm{kg} \mathrm{HM}$ for a burnup of $\sim 55,000 \mathrm{MWd} / \mathrm{MTIHM}$. The total fuel cycle cost of $8.1 \mathrm{mills} / \mathrm{kWh}$ is probably typical of that experienced by PWR utilities, which are already paying higher ore and SWU costs today. If uncertainties are assigned to all of the fuel cycle costs, as was done in the Advanced Fuel Cycle Economic Sensitivity Analysis (Ref A-2), the unit fuel-cycle cost range could be anywhere from 3 to $12 \mathrm{mills} / \mathrm{kWh}$.

\section{Partially Closed Case with MOX and RU Recycle}

Figure A-2 shows a schematic for the case where the PWR is reprocessed and the $1 \%$ fraction ( of heavy metal discharged) of Pu converted to MOX fuel and the 95\% HM fraction of RU converted to $\mathrm{UF}_{6}$, enriched, and the enrichment product made into RU-LEU fuel assemblies. (Note that most of the $95 \%$ fraction of RU ends up as RU-tails from the RU enrichment plant.) The Table A-1 (an output of G4-ECONS) shows the detailed economics of this cycle. It can be seen that the annual cost ( $\$ 9 \mathrm{M} /$ year) of making MOX fuel from the $\mathrm{PuO}_{2}$ product is nearly the same as the credit for equivalent fresh "virgin" $\mathrm{LEUO}_{2}$ fuel assemblies. The annual cost of producing RU-LEU assemblies, however, is significantly smaller than producing an equivalent number of virgin LEU assemblies. The difference is $\$ 5.2 /$ reactor-year, which is in line with the $\$ 4.7 \mathrm{M} /$ reactor-year savings in the earlier calculation, but under slightly different assumptions regarding enrichment plant feed streams. The total fuel cycle cost for this cycle is $9.7 \mathrm{mills} / \mathrm{kWh}$, which is $1.6 \mathrm{mills} / \mathrm{kWh}$ higher than 
the open cycle. It is higher because the cost of reprocessing the PWR fuel and disposing of the wastes amounts to $2.2 \mathrm{mills} / \mathrm{kWh}$ or just over $\$ 1,000 / \mathrm{kg} \mathrm{HM}$.

Table A-1. Economic data for MOX and RU recycle from a PWR

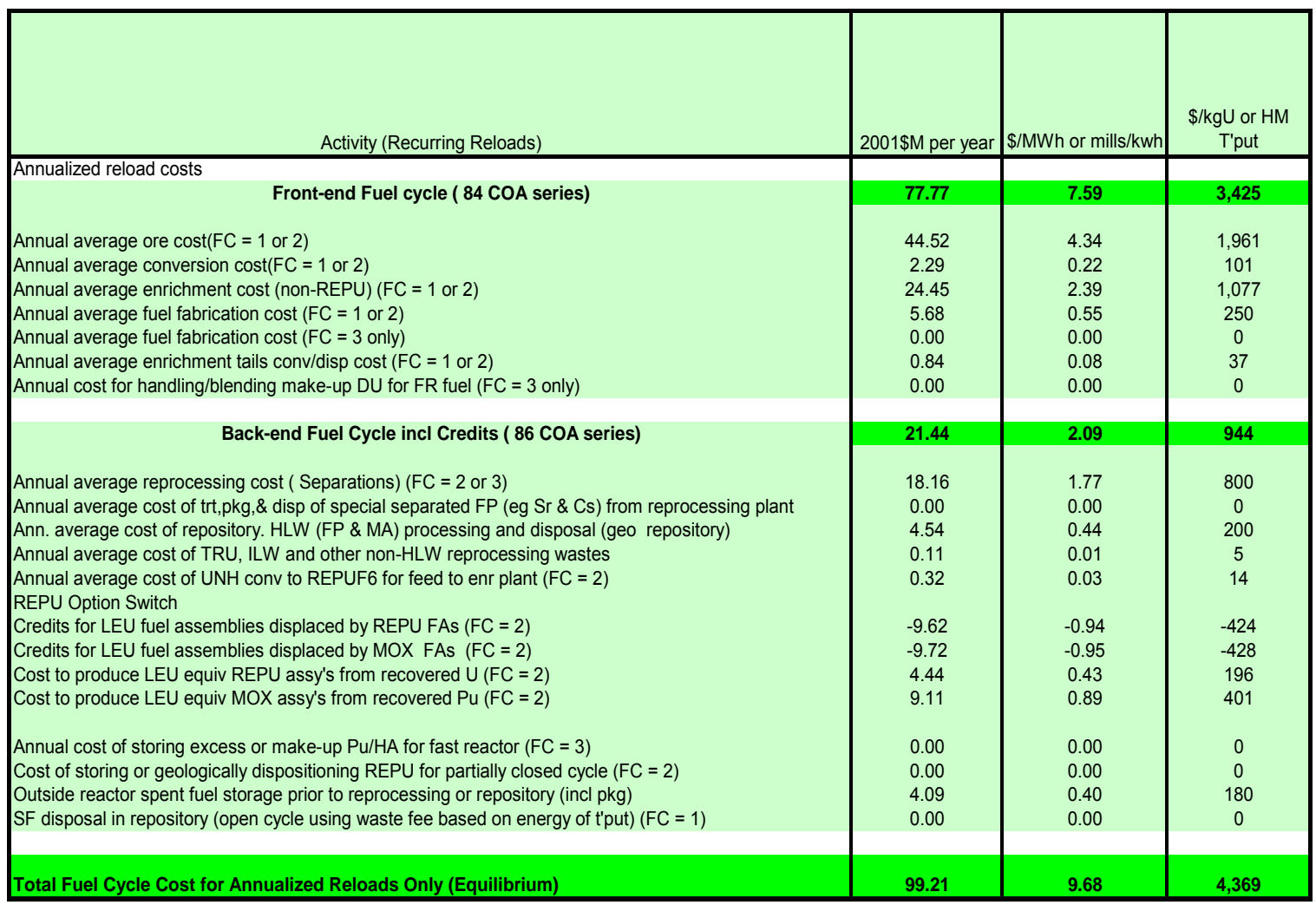

\section{Partially Closed Case with No Recycle of RU}

The third case shown in Fig. A-3 assumes that only the $\mathrm{PuO}_{2}$ product is recycled as LWR MOX fuel and that the RU is converted to $\mathrm{U}_{3} \mathrm{O}_{8}$, packaged, stored, and eventually placed in some sort of permanent geologic storage for a unit cost of $\$ 120 / \mathrm{kg} \mathrm{U}$. The case is essentially the same as the one immediately above, except that there are no charges for RU enrichment or fabrication but also no RU credit. The charges for disposition of the RU amount to $\$ 2.6 \mathrm{M} /$ reactor-year. The total cost for this fuel cycle is $10.4 \mathrm{mills} / \mathrm{kWh}$, which is nearly a mill higher than the case for which the RU is recycled along with the $\mathrm{PuO}_{2}$.

The conclusion that can be drawn from the above is that higher ore and SWU costs increase the incentive for RU (and MOX) recycle. An effort should be started to investigate the facility, cost, and regulatory issues associated with a future U.S. RU recycle effort, such as:

- The need to provide separate centrifuge enrichment facilities to handle RU.

- The need to relicense LWR fuel fabrication plants to handle LEU product assays above 5\% ${ }^{235} \mathrm{U}$ if only RU is used as feed.

- The fuel qualification issues associated with RU-LEU fuel in U.S. LWRs. If the uranium meets all the ASTM specifications, then this is no longer an issue. 
- The disposal issues associated with tails from a RU enrichment plant. Again, if the methodology explained in the body of this report is followed, then the combined tails are essentially indistinguishable from standard enrichment tails.

- The real costs of RU storage and disposal if RU is not recycled.

It should be noted that this type of MOX and RU enrichment is already taking place in Europe. At least two European LWRs are operating entirely on recycled (plutonium and RU) products from LWR spent fuel.

For more information on the unit fuel cycle costs assumed for these G4-ECONS studies, the reader should consult the Advanced Fuel Cycle Cost Basis Report (Ref. A-3). Appendix D of Ref. A-4 discusses the experience of the Swiss utility KKG in recycling plutonium and RU. 


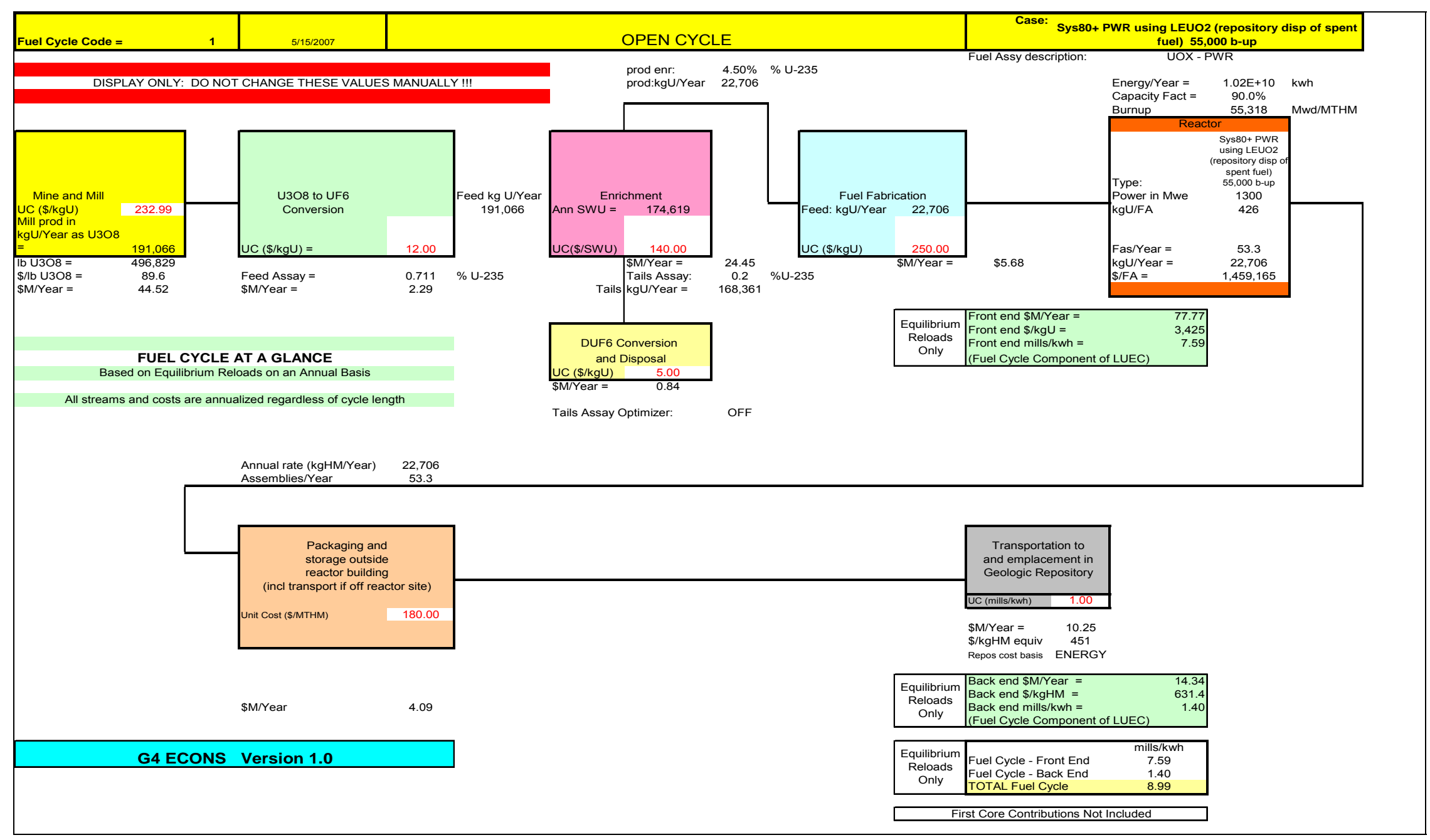

Fig. A-1. Equilibrium fuel cycle material balance and flows for an open PWR fuel cycle option using high values for ore and enrichment costs (all costs and flows annualized). 


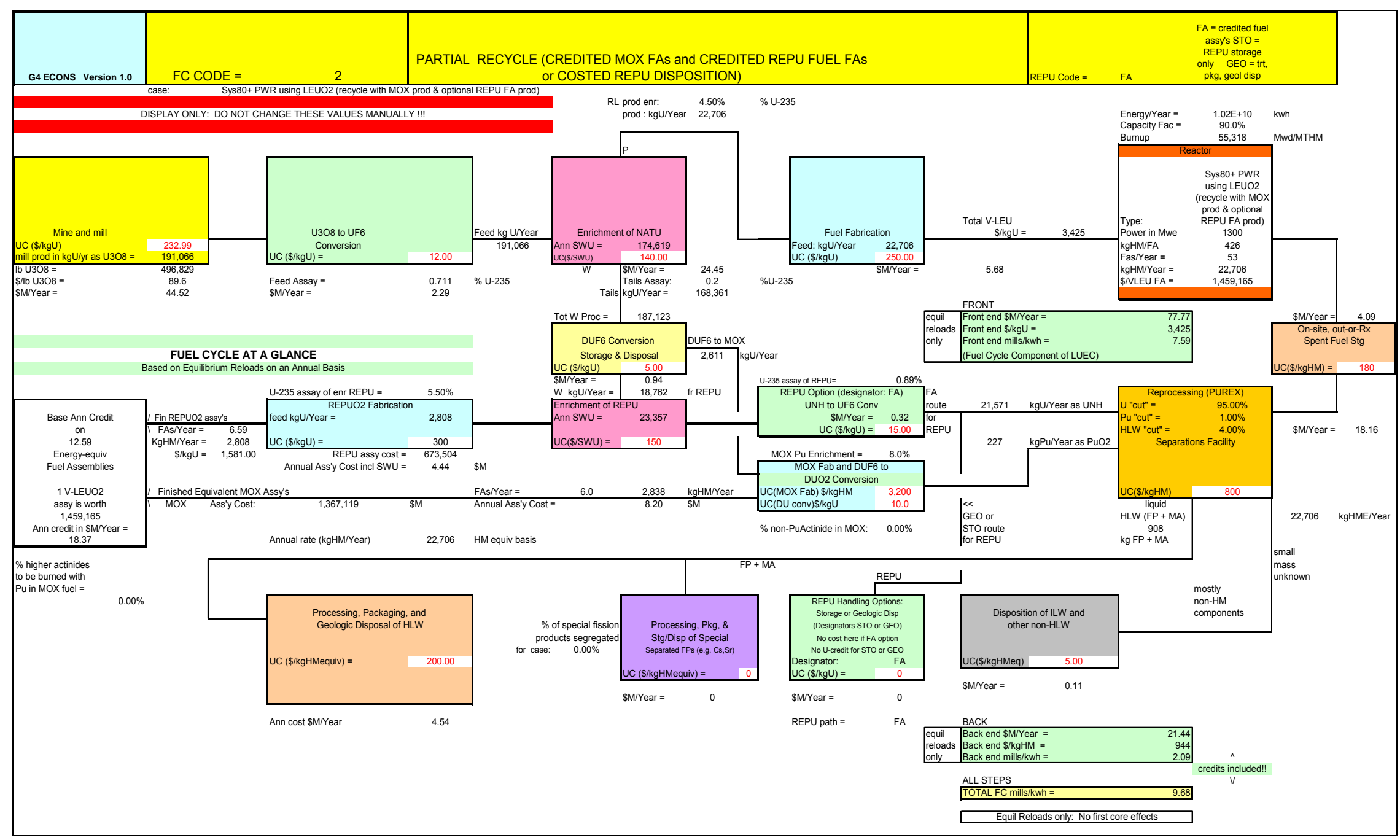

Fig. A-2. Equilibrium fuel cycle material balance and flows for a PWR partial recycle option using high values for ore and enrichment costs (all costs and flows annualized; credit for MOX and RU fuel assemblies). 


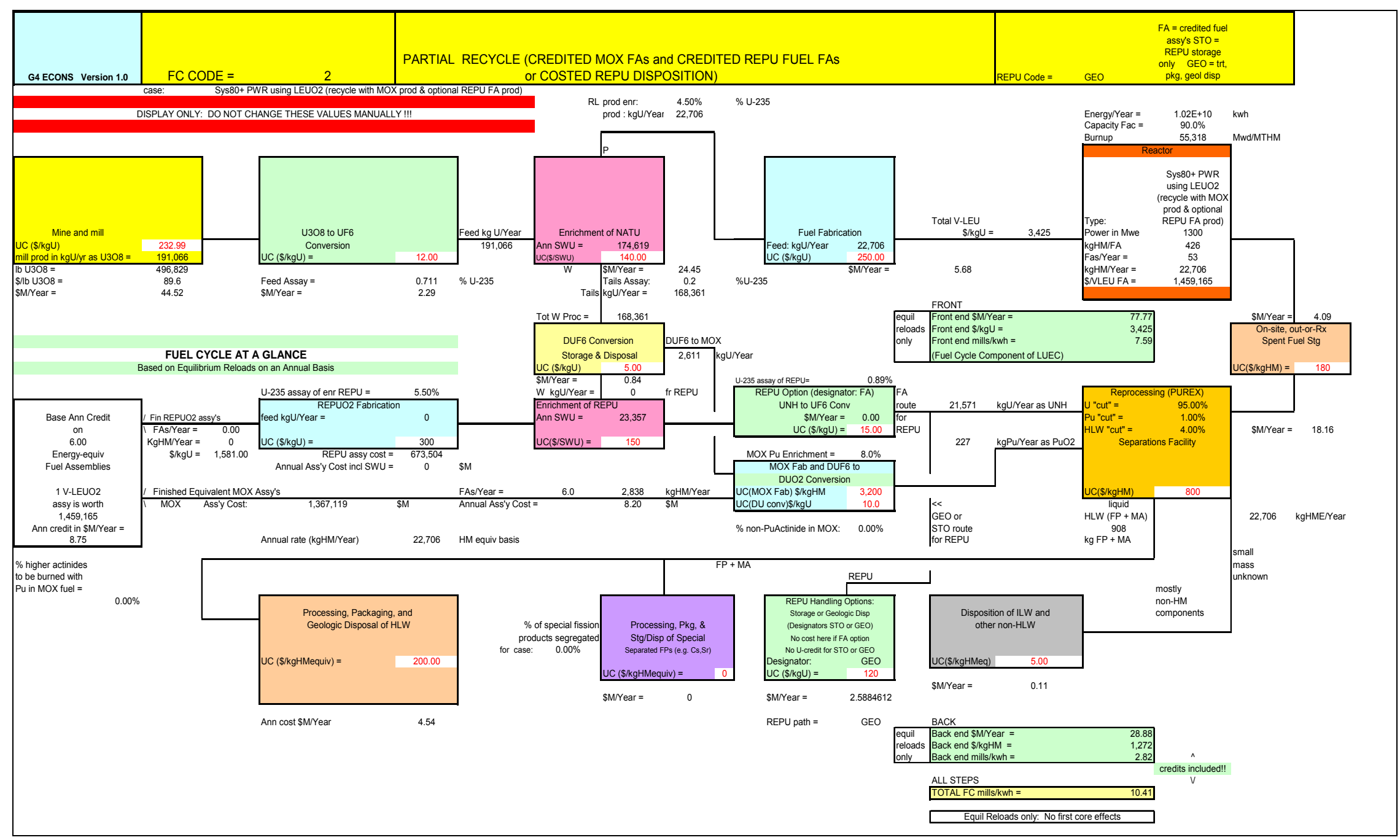

Figure A-3 Equilibrium fuel cycle material balance and flows for a PWR partial recycle option using high values for ore and enrichment costs (all costs and flows annualized; credit for MOX fuel assemblies; REPU discarded). 


\section{Appendix A References}

A-1. Cost Estimating Guidelines for Generation IV Nuclear Energy Systems-Revision 3;

Economic Modeling Working Group of the Generation IV International Forum; November 30, 2006; available at http://www.gen-4.org/Technology/horizontal/economics.htm

A-2. Shropshire, D, Williams, K. et al; Advanced Fuel Cycle Economic Sensitivity Analysis; INL/EXT-06-11947; Idaho National Laboratory; December 2006

A-3. Shropshire, D, Williams, K. et al; Advanced Fuel Cycle Cost Basis; INL/EXT-07-12107; Idaho National Laboratory; March 2007; available at http://www.inl.gov/technicalpublications/Search/Results.asp?ID=INL/EXT-07-12107

A-4. Management of Recyclable Fissile and Fertile Materials; OECD/NEA, Paris, 2007. 


\section{APPENDIX B: U.S. SPENT FUEL INVENTORY AND EXPECTED RU QUALITY}

From the 2002 DOE Nuclear Fuel Data Survey Inventory Assessment, up until July 2002, the spent fuel inventory comprised 70,289 PWR assemblies (30,292 MTHM) and 93,352 BWR assemblies (16,708 MTHM), as seen in Fig. B-1. Using the SCALE 5.1 code package, specifically, the sequences TRITON (in t-depl depletion mode), ORIGEN-ARP, and ORIGEN-S, an approximate estimate for the average RU enrichment in the BWR discharged fuel inventory is $0.77 \mathrm{wt} \%$; the estimated average RU enrichment for the PWR fuel assembly inventory is 0.88 wt $\%$.

The U.S. inventory of SNF, as of July 2002, included 46999.2 MTHM, with 30291.6 from PWR reactors and 16707.6 from BWR reactors. The weighted averaged burnup of all the U.S. $\mathrm{SNF}$ is $33.56 \mathrm{GWd} / \mathrm{MT}$, with that for PWR SNF being $36.3 \mathrm{GWd} / \mathrm{MT}$ and that for BWR SNF being 28.6 GWd/MT; this can be seen from the data plotted in Fig. B-2. The U.S. average for the mass of SNF discharged per year includes approximately two times more mass for PWR SNF than for BWR SNF as seen in Fig. B-3. The initial ${ }^{235} \mathrm{U}$ enrichment of BWR fuel assemblies tends to be significantly less than for PWR fuel as seen in Figs. B-4 and B-5. The trend is towards higher initial enrichments in both BWR and PWR fuel, to enable higher discharge burnups and longer fuel-cycle lengths. The inventory of discharged PWR assemblies tends to a higher burnup than BWR spent fuel, as seen in the shift in the PWR distribution versus that for BWR in Fig. B-6.

The overall RU enrichment for all discharged reactor fuel (as of 2002) is estimated to be $0.84 \mathrm{wt} \%$. The RU enrichment in discharged fuel is seen to be increasing as a result of greater initial enrichment (in higher burnup fuel). For BWR fuel with initial enrichment greater than $3.5 \mathrm{wt} \%$, the average RU enrichment is estimated to be $0.94 \mathrm{wt} \%$. For PWR fuel with enrichment between 4.0 and $4.5 \mathrm{wt} \%$, the RU enrichment is estimated to be $1.00 \mathrm{wt} \%$; for PWR fuel with enrichment between 4.5 and $5.0 \mathrm{wt} \%$, the RU enrichment is estimated to be $1.14 \mathrm{wt} \%$.

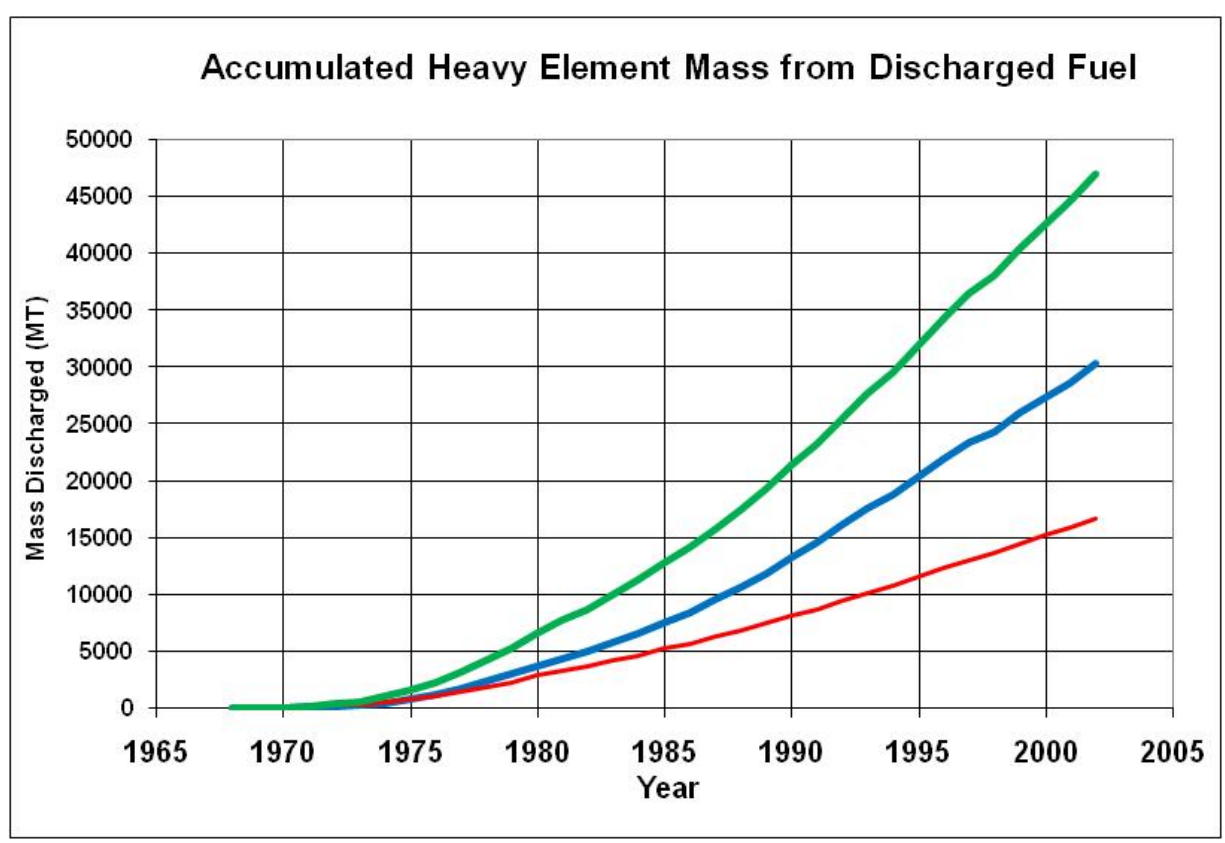

Fig. B-1. The accumulated (integrated) heavy metal mass in U.S. discharged fuel. (blue is for PWR; red is for BWR; green is the total) 


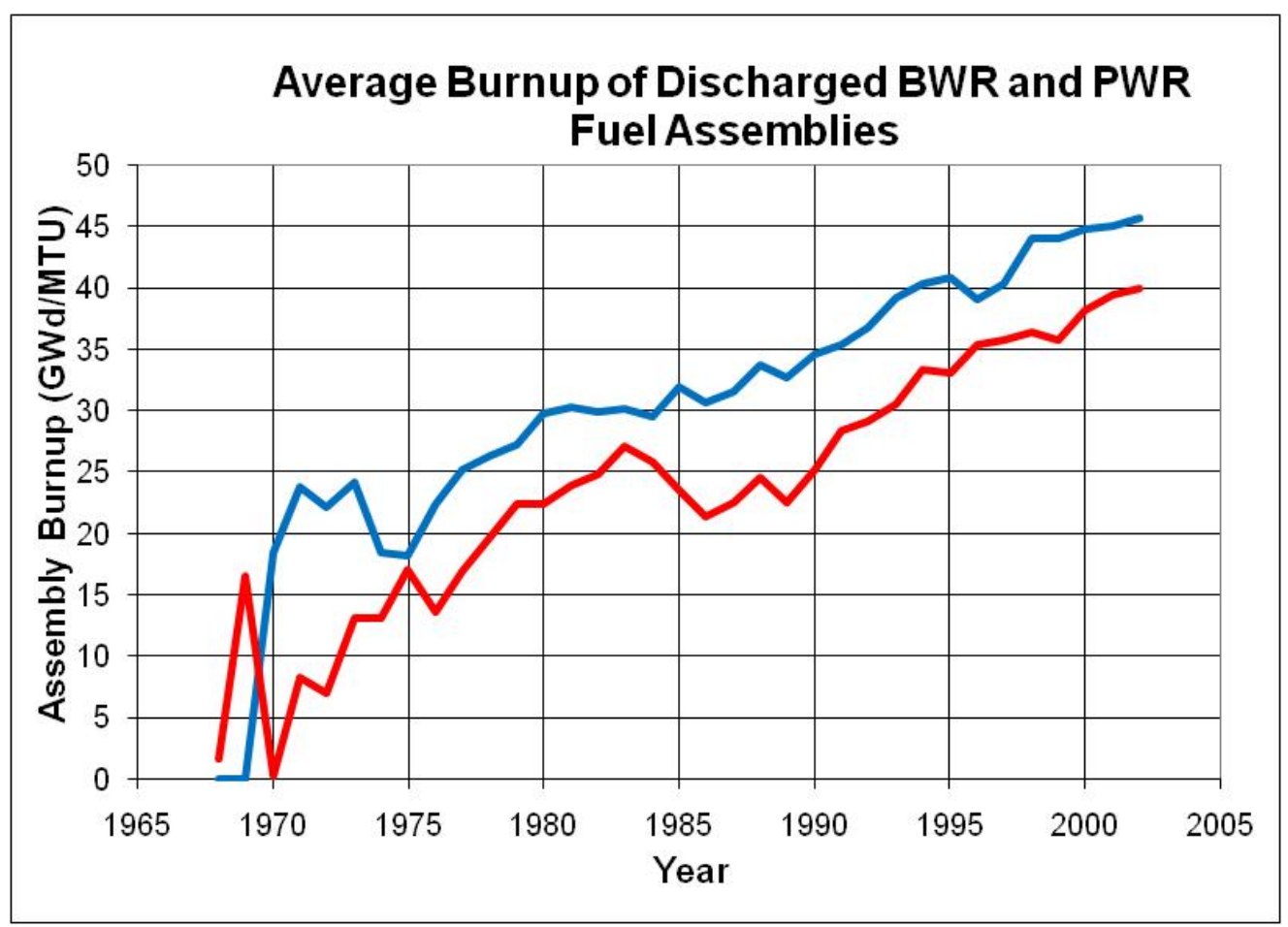

Fig. B-2. Average discharge burnup of U.S. spent nuclear fuel.

(blue is PWR; red is BWR)

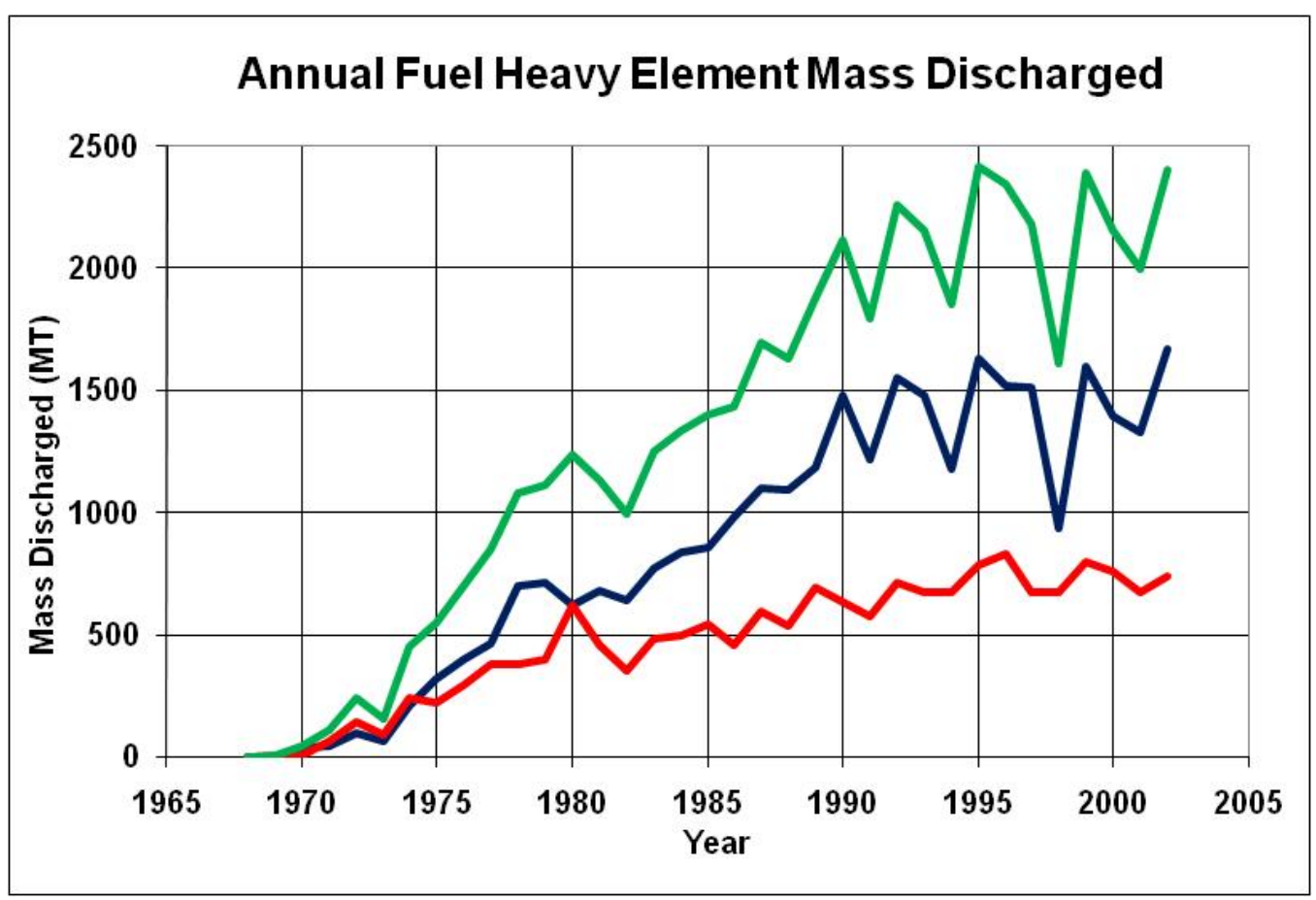

Fig. B-3. Annual heavy metal mass in U.S. discharged fuel.

(blue is for PWR; red is for BWR; green is the total) 


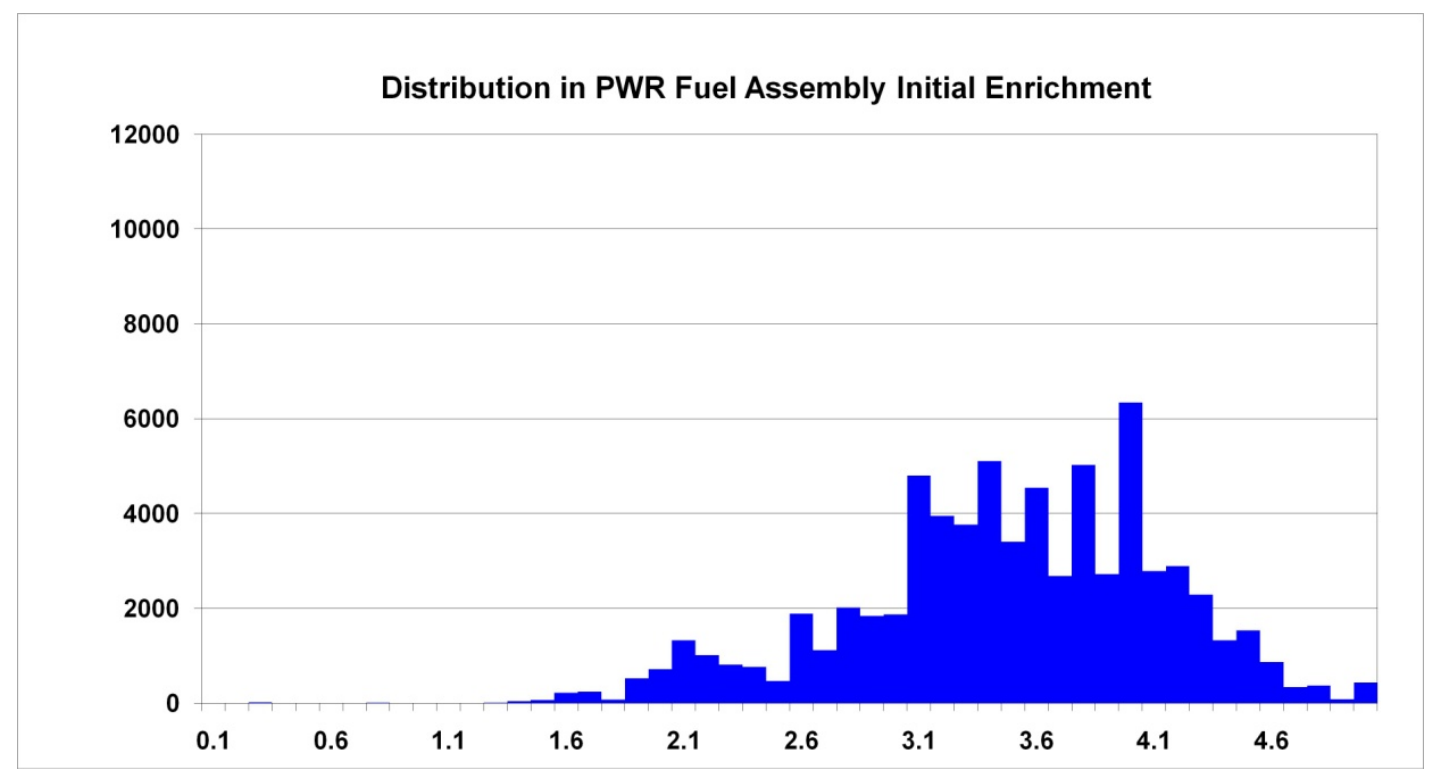

Fig. B-4. Distribution of PWR assemblies by initial enrichment.

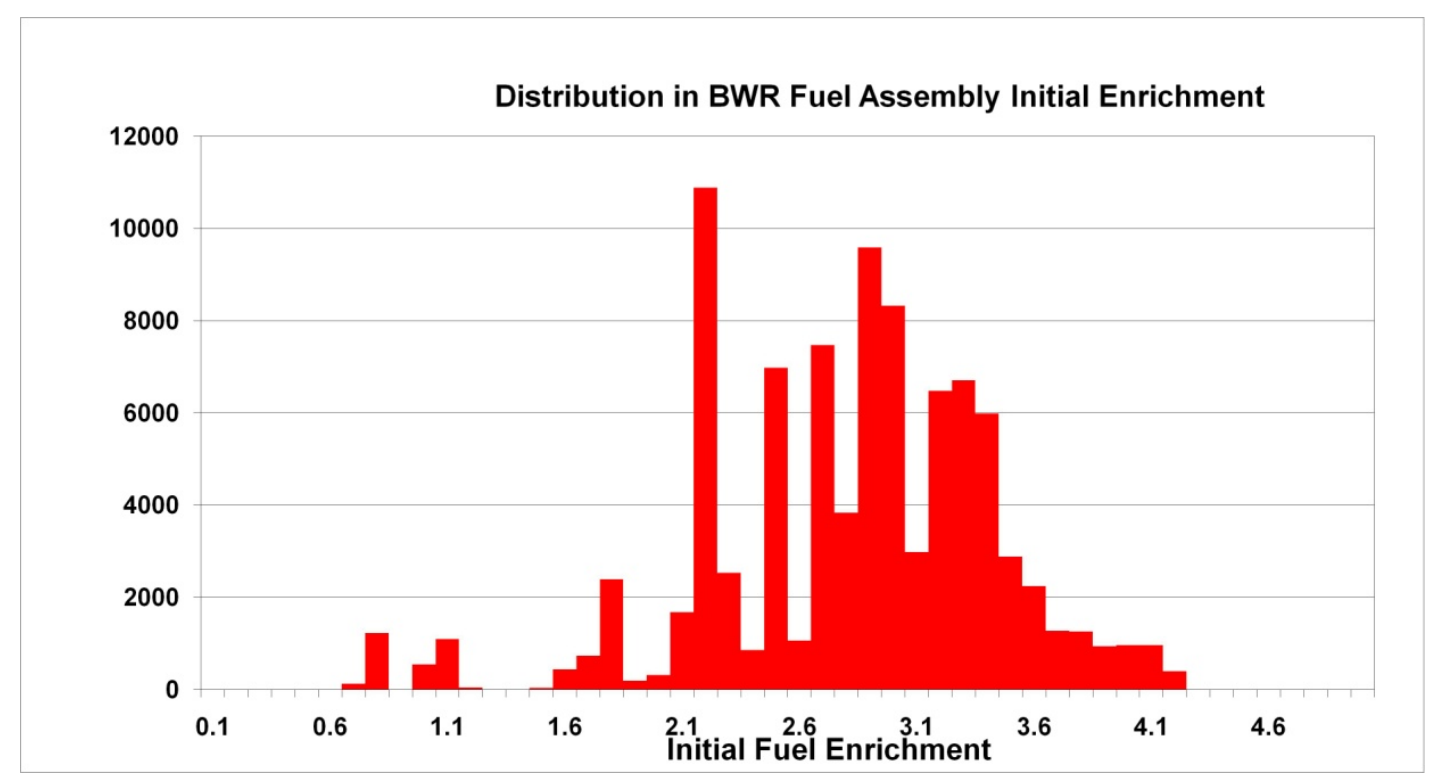

Fig. B-5. Distribution of BWR assemblies by initial enrichment. 


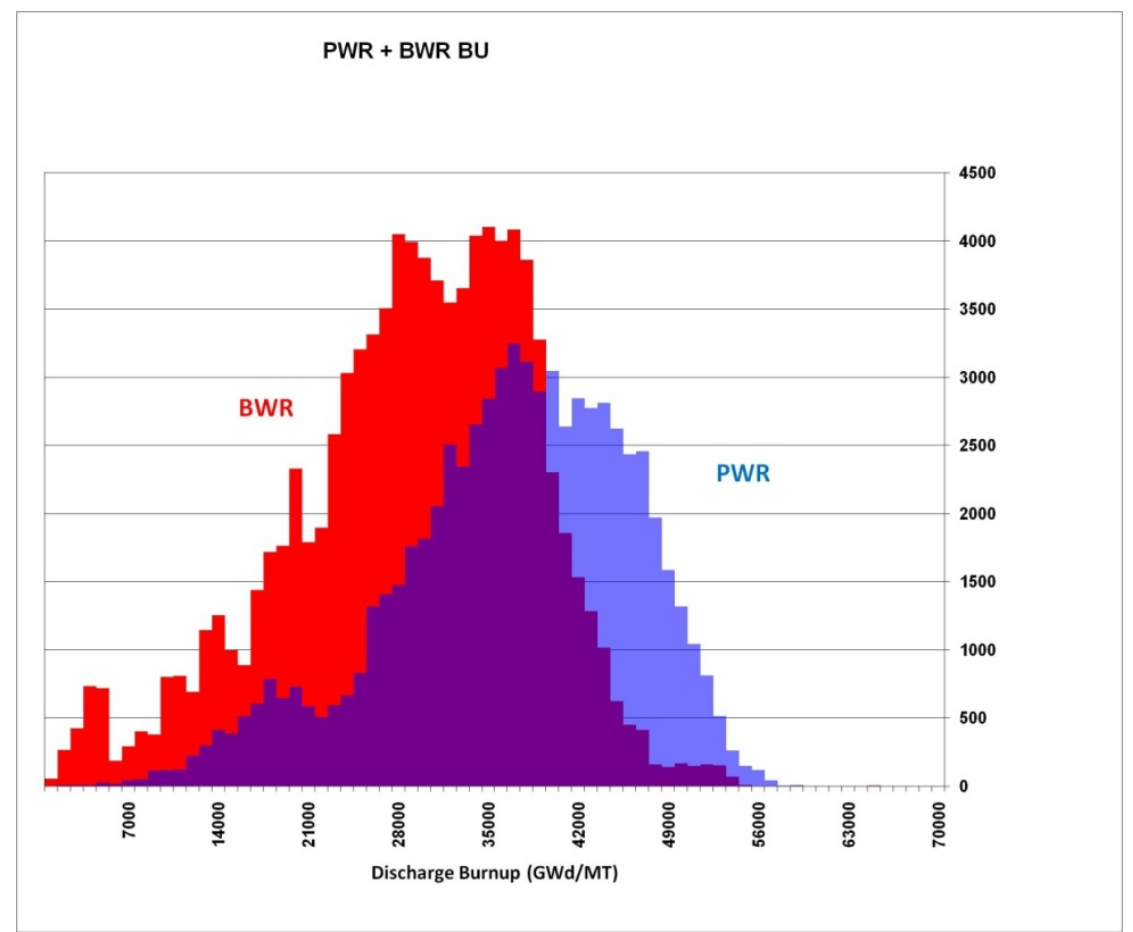

Fig. B-6. Comparison of PWR and BWR distributions of discharge burnup. 